\title{
Likely Social Impacts of Proposed National-Level Policy Initiatives
}

Craig A. Piernot

Mary Alice Rothweiler

Alice Levine

Robin Crews
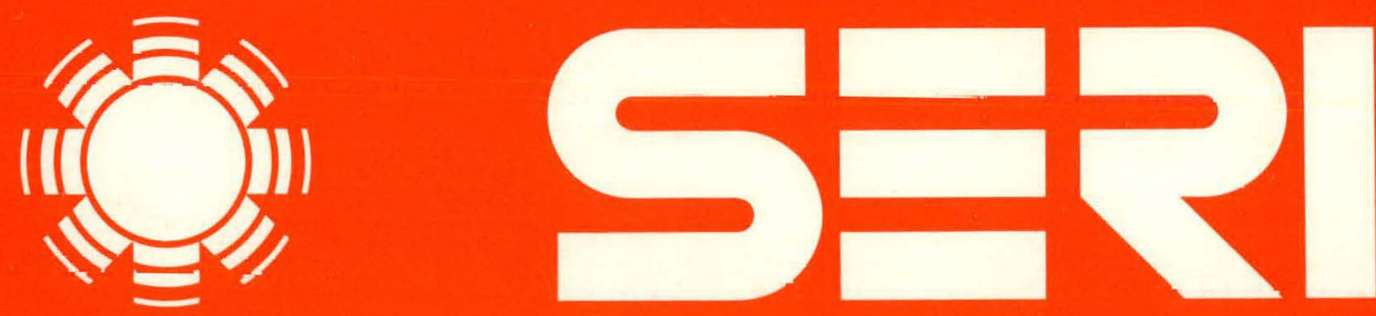

Solar Energy Research Institute

A Division of Midwest Research Institute

1617 Cole Boulevard

Golden, Colorado 80401

Operated for the

U.S. Department of Energy under Contract No. EG-77-C-01-4042 


\section{DISCLAIMER}

This report was prepared as an account of work sponsored by an agency of the United States Government. Neither the United States Government nor any agency Thereof, nor any of their employees, makes any warranty, express or implied, or assumes any legal liability or responsibility for the accuracy, completeness, or usefulness of any information, apparatus, product, or process disclosed, or represents that its use would not infringe privately owned rights. Reference herein to any specific commercial product, process, or service by trade name, trademark, manufacturer, or otherwise does not necessarily constitute or imply its endorsement, recommendation, or favoring by the United States Government or any agency thereof. The views and opinions of authors expressed herein do not necessarily state or reflect those of the United States Government or any agency thereof. 


\section{DISCLAIMER}

Portions of this document may be illegible in electronic image products. Images are produced from the best available original document. 


\author{
Printed in the United States of America \\ Available from: \\ National Technical Information Service \\ U.S. Department of Commerce \\ 5285 Port Royal Road \\ Springfield, VA 22161 \\ Price: \\ Microfiche $\$ 3.00$ \\ Printed Copy $\$ 7.25$
}

\begin{abstract}
NOTICE
This report was prepared as an account of work sponsored by the United States Government. Neither the United States nor the United States Department of Energy, nor any of their employees, nor any of their contractors, subcontractors, or their employees, makes any warranty, express or implied, or assumes any legal liability or responsibility for the accuracy, completeness or usefulness of any information, apparatus, product or process disclosed, or represents that its use would not infringe privately owned rights.
\end{abstract}


SERI $/ T R-743-786$

UC CATEGORY: UC-58

LIKELY SOCIAL IMPACTS

OF PROPOSED NATIONAL-LEVEL

POLICY INITIATIVES

CRAIG A. PIERNOT

MARY ALICE ROTHWEILER

ALICE LEVINE

ROBIN CREWS

MARCH 1981

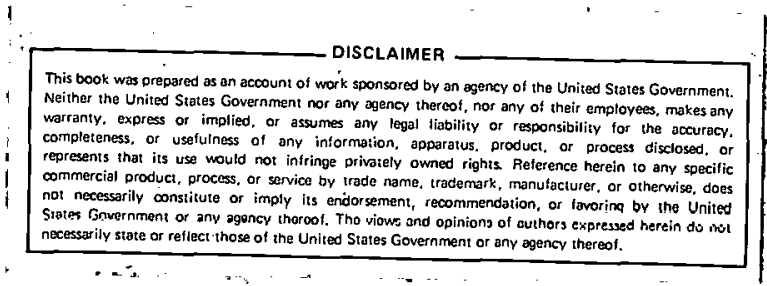

PREPARED UNDER TASK No. 5642.10

\section{Solar Energy Research Institute}

A Division of Midwest Research Institute

1617 Cole Boulevard

Golden, Colorado 80401

Prepared for the

U.S. Department of Energy

Contract No. EG-77-C-01-4042 
THIS PAGE

\section{WAS INTENTIONALLY LEFT BLANK}




\section{PREFACE}

This report describes the results of an investigation of possible social effects of enacting nine proposed national-level policy initiatives to accelerate development and use of solar energy. This study is part of the Technology Assessment of Solar Energy Systems (TASE) project supported by the U.S. Department of Energy, Technology Assessments Division, Assistant Secretary for Environment. The purpose of this study was to identify the general, salient social effects of enactment of national-level policy initiatives to achieve the goal of $20 \%$ solar energy use in the United States by the turn of the century. The objective of the TASE project is to determine the range of potential consequences to the total human environment from widespread use of solar energy technologies in achieving the national goal.

We wish to thank those staff persons at the Solar Energy Research Institute (SERI) who gave generously of their time to review various draf ts of the final report. Special thanks are in order for Ron Ritschard and Ken. Haven, Energy and Environment Division, Lawrence Berkeley Laboratory, and Greg D'Alessio, Project Manager, Technology Assessment Division, U.S. Department of Energy, for their constructive criticisms and suggestions for improvements in the structure and content of the report. It was prepared by SERI under Task No. 5642.10 for the U.S. Department of Energy.

Approved for

SOLAR ENERGY RESEARCH INSTITUTE

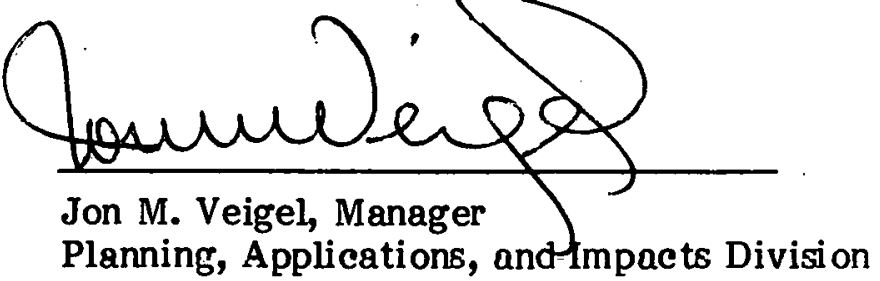


THIS PAGE

\section{WAS INTENTIONALLY \\ LEFT BLANK}




\section{SUMMARY}

This investigation is part of the Technology Assessment of Solar Energy Systems (TASE) project supported by the U.S. Department of Energy, Assistant Secretary for Environment, Technology Assessments Division. The objective of the investigation was to identify important social effects likely to occur if national-level public policy initiatives were enacted to achieve the goal of $15 \%$ to $20 \%$ solar energy use in the United States by the year 2000. The national-level scope of the study required investigation of only general and salient likely effects of each policy initiative. The investigators looked for effects such as changes in the structure or functioning of society or its components that occurred in conjunction with the enactment of a proposed initiative. The value of this study is that it demonstrates that social effects can be identified with policy initiatives regardless of whether those proposals have been made or are planned for the future.

A wide range of federal programs that could increase solar energy use in the nation were grouped into three programmatic options representing three distinct levels of government support. The base-case option would continue existing programs but make them more effective. The practical case would expand current federal support with selected programs designed to achieve specific cost-effective objectives, and the high-priority option would substantially increase federal support through a variety of programs to achieve the national goal of accelerated use of solar energy. The practical case was chosen because of its potential to become the feasible course of government action. This level of government support suggested investigation of the nine proposed policy initiatives introduced in the 96 th Congress. The initiatives are designed to encourage the use of solar energy in these end-use sectors: residential/commercial buildings, industry, utilities, and government. The identification of the likely social impacts of each initiative is presented by end-use sector in Sec. 5.0.

The process of identifying likely social impacts of proposed policy initiatives presented two challenging methodological problems. First, although the growth in social impact studies continues to be rapid, only a few have been done of solar energy technologies (Cambel, et al., 1978; Duffey-Armstrong, 1979; Milne, et al., 1979). These studies and those done of conventional energy resource and technology development, such as mineral extraction and power plant siting, were perused for social impact information. The search resulted in a list of known impacts of energy technology development applicable to the development of solar energy technologies. This list was organized into 14 categories of impacts (e.g., social acceptance) by the conceptual similarity exhibited among impacts. These categories and their impacts are presented in Sec. 4.0 and in Table 4-1. This background social impact information became the raw data of known impacts and served as the basis for investigating the likely impacts of each proposed policy initiative.

A second methodological challenge was to associate information about known social impacts with the set of proposed national-level policy initiatives. This invoked the set of critical problems in social impact assessment presented in Sec. 2.0. In addition, the scope of the study required an identification of impacts rather than an assessment because the likely social effects of each proposed initiative were unknown. Furthermore, because society comprises individuals, groups, organizations, and communities, the effects of each initiative would be spread across society affecting one, some, or all social elements. For example, one impact of the proposed initiative for a $30 \%$ investment tax credit for solar process heat equipment is that it reduces barriers to social acceptance of the technology in the industrial and agricultural end-use sectors. The challenge was to identify the level of social impacting of each initiative because each 
proposed initiative had intended as well as unintended or second-order social impacts. To identify the likely social impacts, each initiative was studied independently by systematically perusing the categories for salient effects. Primary and secondary impacts were specified, and those impacts affecting more than one element of society were presented for each impacted element. The results of the investigation are presented in Sec. 5.0.

A fundamental research question around which there was much controversy and discussion among the sponsors and investigators was, "On whom would each of these proposed initiatives really have an effect?" Section $\mathbf{6 . 0}$ demonstrates the importance of focusing studies of social effects on an identifiable component of society. The case application with social groups constituting the residential rental market demonstrates that more precise and salient impacts can be specified by focusing on identifiable groups. For example, an impact of a proposed tax credit for leased solar equipment is that it reduces financial risk as a barrier to social acceptance of solar technologies for building owners but not for builders or tenants of residential rental property. Focusing the investigation on identifiable groups results in more realistic, accurate, and specific social impact information. It shows clearly who is impacted, how, and to what extent.

In sum, this study report provides the TASE project, DOE, and other readers with general social impact information about the variety of ways in which the American people could be affected by enactment of the proposed public policy initiatives. It identifies the effects of each initiative on individuals, groups, organizations, communities, and society as a whole. In addition, it provides a framework for organizing a myriad of impact information into a set of conceptually exclusive impact categories. It illustrates that social impacts means effects on people as individuals, groups, organizations, and communities as well as on the infrastructure of society. Finally, it demonstrates the importance of specifying an audience of impact by means of a case example from the residential rental market. 


\section{TABLE OP CONTENTS}

Page

1.0 Introduction $\ldots \ldots \ldots \ldots \ldots \ldots \ldots \ldots \ldots \ldots \ldots \ldots \ldots \ldots \ldots \ldots \ldots \ldots \ldots \ldots \ldots$

1.1 The TASE Project $\ldots \ldots \ldots \ldots \ldots \ldots \ldots \ldots \ldots \ldots \ldots \ldots \ldots \ldots \ldots \ldots \ldots \ldots \ldots$

1.2 Purpose of the Study $\ldots \ldots \ldots \ldots \ldots \ldots \ldots \ldots \ldots \ldots \ldots \ldots \ldots \ldots \ldots \ldots \ldots \ldots$

1.3 Recommended Actions ................................. 2

1.3.1 Utilities .................................... 2

1.3.2 Federal Buildings............................... 2

1.3.3 Consumer Protection ............................ 3

1.3.4 Financial Assistance for Solar Energy ................... 3

1.3.5 Tax Credits ................................... 4

1.3.6 State Energy Management Planning .................. 5

1.4 Organization of the Report $\ldots \ldots \ldots \ldots \ldots \ldots \ldots \ldots \ldots \ldots \ldots \ldots \ldots \ldots \ldots$

2.0 Social Impact Assessment $\ldots \ldots \ldots \ldots \ldots \ldots \ldots \ldots \ldots \ldots \ldots \ldots \ldots \ldots \ldots \ldots$

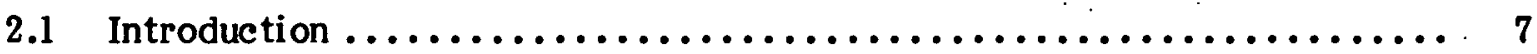

2.2 Defining Social Impact Assessment $\ldots \ldots \ldots \ldots \ldots \ldots \ldots \ldots \ldots \ldots \ldots \ldots \ldots \ldots$

2.3 Critical Problems in Social Impact Assessment ................ 7

2.3.1 Describing Initial Conditions ........................ 8

2.3.2 Defining and Identifying Social Impacts $\ldots \ldots \ldots \ldots \ldots \ldots \ldots \ldots$

2.3.3 Predicting Impacts $\ldots \ldots \ldots \ldots \ldots \ldots \ldots \ldots \ldots \ldots \ldots \ldots \ldots \ldots \ldots \ldots . \ldots \ldots$

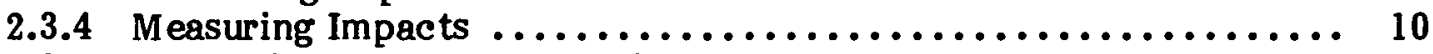

2.3.5 Evaluating Impacts and Projects .................... 11

2.4 Assessment Strategies and Techniques ........................ 11

2.5 Critical Distinctions Between Assessments of Decentralized

Solar Energy Projects and Conventional Energy Projects ............ 13

2.5.1 Units of Analysis .............................. 13

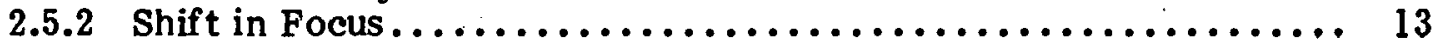

2.5.3 Differences in Scale .............................. 14

2.6 The Need for Modified Approaches to Assessment $\ldots \ldots \ldots \ldots \ldots \ldots \ldots \ldots \ldots$

2.6.1 New Impact Categories ............................ 15

2.6.2 New Analytical Frameworks $\ldots \ldots \ldots \ldots \ldots \ldots \ldots \ldots \ldots \ldots \ldots \ldots \ldots$

3.0 Study Approach and Design $\ldots \ldots \ldots \ldots \ldots \ldots \ldots \ldots \ldots \ldots \ldots \ldots \ldots \ldots \ldots$

3.1 Introduction $\ldots \ldots \ldots \ldots \ldots \ldots \ldots \ldots \ldots \ldots \ldots \ldots \ldots \ldots \ldots \ldots \ldots \ldots \ldots$

3.2 Study Approach $\ldots \ldots \ldots \ldots \ldots \ldots \ldots \ldots \ldots \ldots \ldots \ldots \ldots \ldots \ldots \ldots \ldots \ldots \ldots \ldots \ldots$

3.2.1 Selection of Proposed Policy Initiatives ................. 17

3.2 .2 Identifying Known Impacts $\ldots \ldots \ldots \ldots \ldots \ldots \ldots \ldots \ldots \ldots \ldots \ldots \ldots \ldots . \ldots 18$

3.2.3 Levels of Social Impact $\ldots \ldots \ldots \ldots \ldots \ldots \ldots \ldots \ldots \ldots \ldots \ldots \ldots \ldots \ldots \ldots$

3.2.4 Solar Energy 'lechnologies ........................... 19

3.2.5 Assessing Impacts of Policy Initiatives ................. 19

3.2.6 Case Application: The Rental Housing Market .............. 20

3.2.7 Formulating Recommendations ..................... 20 
TABLE OF CONTENTS (Continued)

4.0 Social Impacts $\ldots \ldots \ldots \ldots \ldots \ldots \ldots \ldots \ldots \ldots \ldots \ldots \ldots \ldots \ldots \ldots \ldots \ldots \ldots \ldots \ldots$

4.1 Defining Social Impacts $\ldots \ldots \ldots \ldots \ldots \ldots \ldots \ldots \ldots \ldots \ldots \ldots \ldots \ldots \ldots$

4.2 Categories of Social Impacts ........................... 21

4.2.1 Financial Aspects of Solar Energy Decision Making ......... 22

4.2.2 Behavior Related to Solar Energy Use ................. 22

4.2 .3 Land-Use Impacts .............................. 23

4.2 .4 Political Institutions Impacts $\ldots \ldots \ldots \ldots \ldots \ldots \ldots \ldots \ldots \ldots \ldots \ldots$

4.2.5 Impacts on the Economy ........................ 23

4.2.6 Information and Education Impacts $\ldots \ldots \ldots \ldots \ldots \ldots \ldots \ldots \ldots . \ldots . \ldots . \ldots . \ldots$

4.2 .7 Social Acceptance.............................. 24

4.2.8 Consumer Demand/Protection Impacts ................ 24

4.2 .9 Health and Safety Impacts ......................... 24

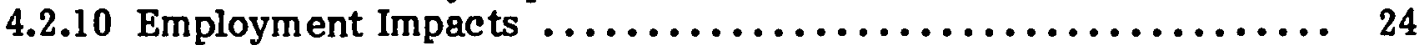

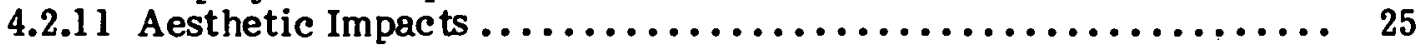

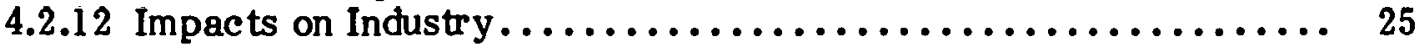

4.2 .13 Quality of Lif e Impacts ........................ 25

4.2 .14 International Implications $\ldots \ldots \ldots \ldots \ldots \ldots \ldots \ldots \ldots \ldots \ldots \ldots . \ldots \ldots$

5.0 Social Impacts of Proposed Policy Initiatives $\ldots \ldots \ldots \ldots \ldots \ldots \ldots \ldots \ldots \ldots$

$5.1 \quad$ Proposed Levels of Government Support .................. 51

5.2 Resi dential/Commercial Buildings Sector Initiatives ............ 52

$5.2 .1 \quad$ Passive Solar Tax Credit ........................ 52

5.2 .2 Solar Development Bank ........................ 56

5.2 .3 Public Housing Assistance Programs ................ 59

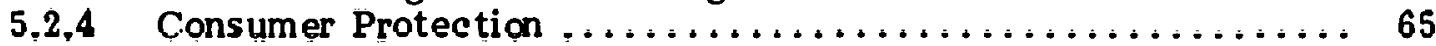

5.2.5 Tax Credit for Leased Equipment................... 70

5.3 Industrial Sector Initiatives $\ldots \ldots \ldots \ldots \ldots \ldots \ldots \ldots \ldots \ldots \ldots \ldots \ldots \ldots \ldots$

5.4 Utility Sector Initiatives $\ldots \ldots \ldots \ldots \ldots \ldots \ldots \ldots \ldots \ldots \ldots \ldots \ldots \ldots \ldots \ldots$

5.5 Government Sector Initiatives ........................ 83

5.5.1 New Civilian Federal Facilities .................... 83

5.5.2 State Energy Management Planning $\ldots \ldots \ldots \ldots \ldots \ldots \ldots \ldots \ldots . \ldots 7$

6.0 Case Application: Residential Rental Market ................... 91

6.1 Characteristios of the Rental Housing Market ................. 91

$6.1 .1 \quad$ Building Structure ............................ 91

6.1.2 Regional Distribution $\ldots \ldots \ldots \ldots \ldots \ldots \ldots \ldots \ldots \ldots \ldots \ldots \ldots \ldots . \ldots \ldots$

6.1.3 Urban/Rural Profile ........................... 92

6.1 .4 Age of Housing Stock .......................... 92

6.1.5 Federal Assistance in Rental Housing .................. 92

$6.2 \quad$ Energy Use Patterns ................................. 93

6.3 Who Pays the Energy Bills? ............................. 93

6.4 Principal Groups in the Rental Housing Market ................ 93

6.4.1 Renters ................................. 94

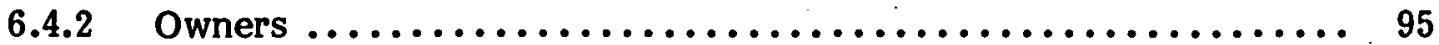


TABLE OP CONTENTS (Concluded)

$\underline{\text { Page }}$

6.4.3 Builders......................................... 95

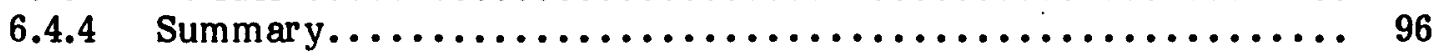

6.5 Social Impacts of Policy Initiatives ....................... 96

6.5.1 Tax Credit for Energy-Efficient Construction ............ 96

6.5.2 Solar Development Bank $\ldots \ldots \ldots \ldots \ldots \ldots \ldots \ldots \ldots \ldots \ldots \ldots, 103$

6.5.3 Funding Program to Assist Low-Income Groups ............. 105

6.5.4 Consumer Protection Program ....................... 110

6.5.5 Tax Credit for Leased Solar Equipment.................. 112

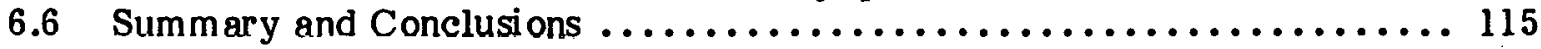

6.6.1 Eff ectiveness of Proposed Policy Initiatives............... 115

6.6 .2 Focus of SIAs $\ldots \ldots \ldots \ldots \ldots \ldots \ldots \ldots \ldots \ldots \ldots \ldots \ldots, 116$

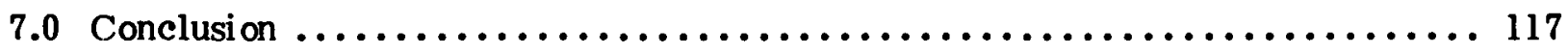

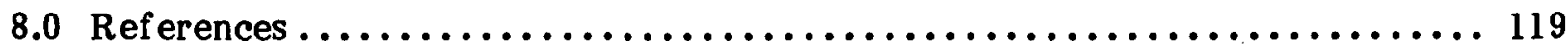

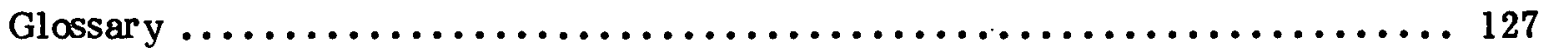


THIS PAGE

\section{WAS INTENTIONALLY}

LEFT BLANK 


\section{LIST OF TABLES}

Page

2-1 Techniques, Types of Analysis, and Research Methodologies

Employed in SIAs .................................... 12

4-1 Social Impacts of Energy Technologies $\ldots \ldots \ldots \ldots \ldots \ldots \ldots \ldots \ldots \ldots \ldots \ldots \ldots$

5-1 Social Impacts of the Policy Initiative to Provide a Tax Credit for Energy-Efficient Construction ..................... 53

5-2 Social Impacts of the Policy Initiative to Establish a Solar Development Bank to Provide Subsidized and Unsubsi dized Resi dential Loans and Guarantees .................. 57

5-3 Social Impacts of the Policy Initiative to Enhance Solar Use by the Poor Through Two Interrelated HUD Housing Assistance Programs

5-4 Social Impacts of the Policy Initiative for Consumer Protection

5-5 Social Impacts of the Policy Initiative to Extend Investment

Tax Credit to Residential Leased Solar Equipment

5-6 Social Impacts of the Policy Initiative for $30 \%$ Tax Credit or Expensing for Solar Process Heat Equipment for Industry and Agriculture.

5-7 Social Impacts of the Policy Initiative Affecting the

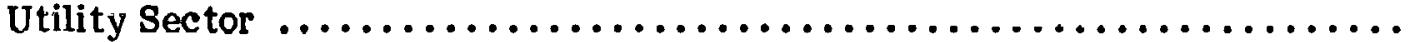

5-8 Social Impacts of the Policy Initiative to Require New Civilian Federal Facilities to Use Passive Solar Design and Cost-Effective Active Sulur. Systems

5-9 Social Impacts of the Policy Initiative to Give States Additional Funds for Energy Planning and Management

6-1 Income Comparison: Homeowners vs. Renters, 1977

6-2 Social Impacts on Residential Rental Groups of a Tax Credit for Energy-Efficient Construction.

6-3 Social Impacts on Residential Rental Groups of a Solar Development Bank

6-4 Social Impacts on Residential Rental Groups of Federal Funding of Low-Income Housing 


\section{LAST OF TABLES (Concluded)}

$\underline{\text { Page }}$

6-5 Social Impacts on Residential Rental Groups of a Consumer

Protection Program ................................ 111

6-6 Social Impacts on Residential Rental Groups of a Tax Credit for

Leased Solar Equipment .............................. 113 


\section{SECTION 1.0}

\section{INTRODUCTION}

\subsection{THE TASE PROJECT}

This investigation is part of the Technology Assessment of Solar Energy Systems (TASE) project supported by the U.S. Department of Energy (DOE), Technology Assessments Division/Office of Technology Impacts, Assistant Secretary for Environment. The primary objective of the TASE project is to determine the range of potential consequences to the environment and to public health and safety resulting from widespread implementation of major solar resource technologies in accordance with the national goal set by President Carter for the year 2000. The results of the project are intended to assist DOE policy makers in determining the optimum course for solar energy deployment considering public benefits and environmental and socioeconomic impacts.

The importance of a new technology to society is that it alters existing patterns of human behavior and choice. The new patterns of behavior and choice that are established impact society unevenly; some social groups gain advantages at costs to others. Technology, therefore, contributes to and is part of social group interaction and formation. As a consequence, it is appropriate that technology assessment include social analysis (Freeman, 1974).

The process of selecting energy technologies for inclusion in the mix of energy-producing systems for our society involves more than technological choices. Of equal importance are interdependent social, political, and economic choices. By themselves, technological choices of energy systems cannot adequately inform society about the range of impacts associated with those choices. As a consequence, the choice of energy technologies is enlightened by information acquired through both technological and social assessments. This study adds essential and important information about likely social, political, and economic effects of proposed policy initiatives to the technology assessment of solar energy. The findings presented here can assist DOE in determining both the preferred course for solar energy development and its contribution to the future mix of energyproducing systems for our society.

\subsection{PURPOSE OF THE STUDY}

The purpose of this study was to identify the general, salient social effects likely to occur if national-level public policy initiatives were enacted to achieve the goal of $20 \%$ solar energy use in the United States by the year 2000. Nine federal policy initiatives were selected for investigation from the broad set of proposals introduced in the 96 th Congress. A wide range of likely social effects were identified for each of the selected policy initiatives. In this study, a social impact refers to a change in the structure or functioning of society that occurs in conjunction with a policy initiative. The national scope of the study required an investigation rather than an assessment of social impacts.

This study report provides the TASE project, DOE, and other readers with general social impacts information about the variety of ways in which the American people could be affected by cnactment of the proposed public policy initiatives. It identifies the effects of each initiative on individuals, groups, organizations, communities, and society as a whole. In addition, it provides a framework for organizing a myriad of impact informa- 
tion into a set of categories of social impacts. And, it illustrates the importance of specifying an audience of impact by means of a case application from the residential rental market.

\subsection{RECOMMENDED ACTONS}

The following set of recommended actions for DOE flows out of the investigation of social impacts likely to occur in conjunction with enactment of each of the proposed policy initiatives. In addition, these recommendations will assist DOE in fulfilling the Domestic Policy Council recommendation that the Federal Government take effective action to accelerate use of solar energy. Because each of the nine proposed policy initiatives was unique and distinct from the others, the initiatives were studied independently. The uniqueness of each initiative made aggregation of impact findings acruss llie set of initiatives invulid. As a consequence, the study offers recommentations for off $\theta 0-$ tIve action for each policy initiative. These recommendations are presented below with brief statements of their attendant positive social effects. The basis for ereh recom= mendation is presented with its policy initiative in Sec. 5.0.

Six categories of recommendations are presented to help DOE participate in implementing the proposed policy initiatives to accelerate solar energy use. Within each category, areas of recommendation are bulleted and are followed by specific recommendations and the likely social effect of the recommended action.

\subsubsection{Utilities}

- Rural Electric $\Lambda$ dministration (REA) Lour Program

It is recommended that DOE assist in setting guidelines for a loan program, both in establishing the appropriate level of lnan subsidy and in developing a loan application evaluation format, and to contribute funding to the REA Loan Program.

Social Effect: This action would imply that higher subsidies would be available, maling solar energy techrolugies accesstble to a larger range of rural income groups.

- Water and Power Resources Service and U.S. Army Corps of Engineers Expansion Plans

It is recommended that DOE provire technical assistance to thr two agencies whose focus has been centralized power generation.

Social Effect: This would help each agency develop plans for renewable energy power generation at the sites of existing power generation.

\subsubsection{Federal Buildings}

- Office of Management and Budget

It is recommended that DOE provide technical assistance to evaluate the costeffectiveness of proposed solar installations for federal buildings. 
- Other Agencies of the Federal Government

The recommendation is that DOE provide technical assistance to federal agencies that are designing solar applications for specific buildings, whether new or retrofit.

Social Effect: . This action would serve to demonstrate to state and local government the effectiveness of solar water and space heating systems as supplements and alternatives to conventional systems.

\subsubsection{Consumer Protection}

- Testing and Certification Program

It is recommended that DOE extend cooperative eff orts with the National Bureau of Standards to set standards for solar product testing and certification and to establish procedures to analyze financial needs of small solar businesses before they would be required to initiate the equipment certification process.

Social Effect: This action would reduce the time delays in equipment certification and establish procedures to safeguard financially tight small businesses from delays that may be detrimental to business viability.

- Standardized Product Inf ormation

Two recommendations are made: (1) that DOE assist the Consumer Product Saf ety Commission in establishing unif orm saf ety standards for solar equipment used in residential buildings and (2) that DOE cooperate with the Occupational Safety and Health Administration (OSHA) in establishing uniform safety standards for solar equipment used in commercial and industrial buildings.

Social Effect: These actions would extend consumer confidence in and foster acceptance of solar equipment. Additionally, safety standards would protect and ensure the viability of the industry's small businesses.

- Warranty Insurance Program

It appears that private insurers have the capacity to insure warranties.

Social Effect: A federal warranty insurance program may immediately increase the cost of solar equipment to consumers.

\subsubsection{Financial Assistance for Solar Energy}

- Solar Development Bank

It is recommended that DOE provide technical assistance to the agency that administers the Bank and contribute to the Bank's initial capital.

Social Effect: The Bank would create incentives for financial institutions to establish solar loan programs and would extend access to solar equipment to a 
wider range of income groups. Indirectly, the Bank creates business and jobs in the solar industry.

- HUD Housing Assistance Programs

Low-Income Loan Program: It is recommended that DOE provide both technical assistance and funds for 'a loan program so that low-income individuals may purchase solar energy equipment.

Social Effect: Loans to low-income people would reduce the proportion of their incomes expended for energy and would contribute to neighborhood stabilization by reducing building abandonment by tenants and landlords.

Solar Public Housing: It is rernmmended that DDE assist HUD with solar onorgy system evaluation procedures and the design of prototype solar applications for new public housing.

Social Effect: This action would expedite the incorporation of solar energy systems in new public housing.

- Department of Labor

It is recommended that DOE help to establish vocational training programs in solar-related trades by providing technical assistance for solar energy technologies.

Social Effect: The result would be workers trained specifically to install solar cquipment.

\subsubsection{Tax Credits}

- Tax credit for energy-efficient construction

It is recommended that DOE cooperate with the National Bureau of Standards to establish building performance standards for passive solar construction.

Social Effect: This action would ensure the energy efficiency of passive solar buildings.

- Tax credit to solar equipment leasing companies

It is recommended that DOE cooperate with the Internal Revenue Service to establish a level of tax credit.

Social Effect: This action would encourage the use of solar energy in owneroccupied and rental property. A substantial barrier to using leased solar equipment on rental property exists in tenant-landlord relations.

- Expanded investment tax credit for industrial and agricultural process heat equipment

It is recommended that DOE assist the Internal Revenue Service in establishing eligibility criteria for an expanded investment tax credit. 
Social Effect: This action would encourage industrial and agricultural financiers to fund solar process heat systems.

\subsubsection{State Energy Management Planning}

- Requirements that states develop energy management plans

It is recommended that DOE provide technical assistance to states in energy planning and make funds available to states for developing energy management plans.

Social Effect: This action would ensure state-level energy planning, increase participation in energy planning by utilities and the energy industry, and expand public knowledge of the actors in and process of state energy planning. However, the majority of states will require substantial time and financial resources to develop energy plans, possibly delaying or terminating local energy activities in those states. Requiring state energy management plans for federal funding could seriously constrain local energy planning and projects.

In summary, the status of DOE as the lead agency for energy-related issues and actions at the federal level implies that the Department must undertake those actions and initiate appropriate cooperative activities with other federal agencies to ensure optimum deployment and use of solar energy within the Federal Government and society.

\subsection{ORGANIZATION OF THE REPORT}

In the following sections of this report the important components of the investigation are elaborated. Section 2.0 defines social impact assessment, discusses critical problems in the assessment process, and presents assessment strategies and techniques. Section 3.0 describes the approach used to identify likely general social impacts of each of the proposed policy initiatives and to specify the level of social impact associated with each. Section 4.0 defines social impacts, discusses categorizing impacts, and presents 14 categories of social impacts. The identification of social impacts of energy development and the categorization of them were important initial tasks in this study. In Sec. 5.0, the proposed policy initiatives are presented with the impacts likely to occur in conjunction with each initiative. Likely impacts are presented by both the level of social impact and the solar energy technology associated with the impact. Section 6.0 presents a case application of the impacts identification strategy developed in this study in the context of the residential rental housing market. A concluding section summarizes major findings and specific implications for additional research of the social effects of solar energy development. 


\section{SERा}


SECTION 2.0

\section{SOCIAL IMPACT ASSESSMENT}

\subsection{INTRODUCTION}

In this section, social impact assessment (SIA) is defined. In addition, critical problems associated with each component of social impact assessment are discussed and various social impact assessment strategies and techniques are introduced. Three critical distinctions among social impact assessments of decentralized solar energy projects and conventional energy projects are discussed. These distinctions highlight the need for modified approaches to social impact assessment if assessments of solar energy projects are to be meaningful to decision makers.

\subsection{DEFINING SOCIAL IMPACT ASSESSMENT}

Policies, programs, and projects* have certain effects on natural and human environments. Some effects on people may be positive (e.g., employment, enhanced quality of life) or negative (e.g., loss of income, impairment of physical health due to air pollution). Similarly, project effects may be unintended (e.g., alienation) or intended (e.g., increased municipal revenues). The purpose of social impact assessment is to identify and analyze the significant social impacts expected to accrue from projects.

Social impact assessments do not always provide answers to pressing social impact problems. The value of SIAs, in fact, is that they raise questions and provide relevant social impact information to decision makers. As a tool to help planners and decision makers better understand the consequences of projects, a SIA contributes to the formulation of policies that maximize beneficial and minimize adverse impacts on human beings.

\subsection{CRITICAL PROBLEMS IN SOCIAL IMPACT ASSESSMENT}

Social impact assessment is a relatively new endeavor. Although significant advances have been made during the last 10 years, social impact assessment still faces many critical problems. The fundamental source of these problems is that the context within which social impact assessment is conducted is extremely complex. There is no single model that can explain or predict the complex interaction of social factors and social impacts. In part, this has resulted in a tendency for most social impact assessments to be atheoretical (Gouldner, 1970). The complexity of the social contexts of projects will remain constant, but the development of theory and the building of models relevant to social impact assessment will improve as SIA matures.

Two types of social impact assessments are being conducted: "social impact research" of completed or ongoing projects and "social impact forecasts" for proposed projects (Olsen and Merwin, 1977).** The difference between social impact research and forecasts is

*Projects refers to projects, programs, or policies that are the source of social impacts.

**"Forecasts" as used here are not limited to demographic trend extrapolations; rather, they include an array of SIA techniques and types of analysis. 
that forecasts investigate likely future impacts. Except for the component of prediction, both types of assessment perform the following research functions:

- Describe the initial conditions of an impact situation

- Define and identify social impacts, impact groups, and impact areas

- Predict the social impacts of projects (this component is unique to forecasts)

- Measure impacts

- Evaluate impacts and projects

Each of these assessment components has inherent problems, In this section, snme of these problems are discussed.

\subsubsection{Describing Initial Conditions}

The description of initial conditions of an impact situation provides baseline social data from which changes resulting from projects can be measured. As such, "it constitutes a 'before' measure of social conditions-before the effects of planned intervention are felt by impacted individuals, organizations, institutions and communities" (Finsterbusch and Wolf, 1977, p. 153).

Several problems are associated with describing the initial context. One problem involves specification of those factors relevant to the interaction between the project and the social context. Another problem involves discrimination between changes due to the impacts of the project and those due to the dynamics of the social context. In assessing the Impacts of completed or ongoing projects, the description of initial conditions usually depends on the availability, reliability, and validity of secondary data. Thus, the ability to discriminate between changes due to project impacts and those due to the dynamics of the context will be constrained by the quality of secondary data. Successful discrimination between types of change is also a function of the ability to identify relevant factors for comparison for proposed projects; however, identification of relevant factors is less of a problem because of opportunities to design assessment strategies and collect primary data prior to project implementation.

\subsubsection{Defining and Identifying Social Impacts*}

There is no established, standard definition of social impacts. Generally, however, social impacts "refer to all changes in the structure and functioning of [society] that occur in conjunction with [a project]" (Olsen and Merwin, 1977, p. 44). Social impacts, however, include changes as well as the phenomena that undergo changes. For example, social impacts related to changes in consumer behavior such as increased adoption of solar energy technologies include exposure to the manifestations of increased solar energy adoption (i.e., more solar energy systems purchased and installed) as well as the changes in attitudes and behaviors of those adopting solar energy (i.e., modifications in lifestyles and satisfaction with solar energy systems). The fact that social impacts can be seen as

*The extent of knowledge of social effects determines whether the problem is one of identifying impacts that one knows about or defining the effects one would expect to find upon investigation. 
changes and the phenom ena that experience changes is but one of the dimensions of complexity surrounding impact identification.

Another problem involves discriminating between project impacts and changes that occur whether or not a project takes place. "With" and "without" project scenarios are useful in identifying these different types and degrees of social change. A related problem is that social impacts not only result from a project, but also can-and usually do-occur in conjunction with, and interact with, a project. As a consequence, interactions between impacts and projects and interactions among impacts can produce second-order and third-order impacts.

The identification of social impacts related to a project is further complicated by the fact that they tend to be both dynamic and complex. Social impacts are dynamic in that they involve, among other elements, social change. They are complex for three reasons. First, the level of impact tends to be multiple rather than singular. Rarely is a community affected by a project without social groups and individuals within the community also being affected. Since the type and degree of impact will vary by social level of impact, impact identification becomes complex. Another reason impact identification is complex is that there are many different types of impacts (e.g., beneficial or adverse, primary or secondary, intended or unintended, immediate or latent, of short or long duration). Finally, impact identification is complex because impacts occur in numerous areas of society (e.g., impacts on infrastructure, attitudes, behavior, and process). Impacts can include demands placed on human services (e.g., health care), on people's perceptions (e.g., the relative merits of a project), on behavior (e.g., people's adoption of a new technology), and on process (e.g., the way in which communities choose to become involved in decisions made about their energy futures).

\subsubsection{Predicting Impacts}

The problems of predicting impacts are unique to social impact forecasts and are not encountered in impact research. There are three basic problems. First, as noted, the social environment is dynamic rather than static. Second, the social environment is not governed by timeless laws. The laws governing people in society change as people and society change. Third, predictions attempt to anticipate the future state of society in the absence of empirical data about the future. In sum, impact predictions are heavily dependent on int uitive judgment (Helmer, $1 y^{\prime}\left(7^{\prime}\right)$ ).

In addition to these fundamental problems, others emanate from the fact that few SIAs have been performed and the range of investigations has been diverse-from highway sitings and water resource development to power plant sitings and mineral extraction. As a result, many social impacts remain unidentified at present (Duhl, 1967). Moreover, impacts generally have been identified through investigations of likely social impacts, rather than through the testing of theory (Shields, 1977). Thus, although findings lack explanatory and predictive power, decision makers utilize these findings in important decisions about proposed projects with future social effects.

Predicting social impacts is further complicated by their very nature. One problem ar ises because of their dynamic nature. While some immediate impacts may be predicted with relative certainty, how they will change over time is difficult to assess. A second problem involves the creation of new, second-order impacts through the interaction of initial impacts with the project. For example, because of public complaints to a local utility about infrasound generated by a nearby large wind energy conversion system 
(WECS), the project was affected and the schedule of operation of the WECS changed. In turn, the change in operating schedule may have created another social impact if residents in the vicinity conceive of the WECS as incapable of operating without producing infrasound. The cumulative social effect of these two impacts may be a belief that WECS cannot generate power in an environmentally and socially acceptable manner. Public acceptance of WECS may affect the local utility's decision about whether to adopt the technology for power generation. In sum, predicting second-order impacts is as essential to social impact assessment as is predicting first-order impacts. Moreover, because of the complex nature of the social context of a project, SIAs can best help to predict the social context through estimation of the interactions of possible social impacts.

\subsubsection{Measuring Impacts}

Impacts must be measured after they are identified. It is not enough to observe that some impacts are severe and others are not, nor is it appropriate to merely speculate about the future. To assess the social impacts of a project, their range, rates, intensity, duration, and frequency must be measured.

There are numerous problems associated with the measurement of impacts. Although some social phenomena are easily described and measured, many have not lent themselves to quantitative analysis. To date, most SIAs have been dominated by quantitative economic measures (e.g., measures compatible with some type of cost-benefit analysis). Some social phenomena can be discussed in quantitative or economic terms, or both. For example, community growth can be measured by rate of population growth and population density. However, most phenomena of interest in an assessment of impacts on society are not economic and cannot be measured quantitatively. Specifically, projects affect lif estyles, attitudes, and quality of life. For example, impacts on one component of quality of life, "community cohesion," might be approached through descriptive measures such as individual perceptions of access to the energy decision-making process, social groups' perceptions of access to power, and social groups' perceptions of increases or decreases in consensual decision making. Because community cohesion involves variables more effectively measured in descriptive terms, energy decision makers ought not to expect to measure community cohesion in the same way ecologists measure tons of pollutants in the atmosphere from a particular industry or energy facility. Instead, a variety of qualitative and descriptive measures are appropriate and will produce a more meaningful social impact assessment.

Another problem in measuring impacts stems from the nature of change in social phenomena. Measuring impacts involves estimating variables of change. Two of the variables to which impact measurement must be sensitive are the rate of change and the duration of change. Some changes may occur rapidly; some, gradually; sume, consistently; some, erratically. Some changes are of short duration and some are permanent. Examples of the way in which the rate and duration of change affects these impacts can be drawn from the nuclear reactor accident at Three Mile Island. The accident produced rapid and widespread confusion about possible danger to life or health among the residents of Harrisburg. Some of the confusion was removed when residents were permitted to return to their homes, but confusion continues about the threat to safety of radioactive gas and water. The extent of confusion has diminished, but the confusion endures. People are still uncertain about the saf ety of the plant. Impact measurement, then, to be valid and meaningful, must be sensitive to the variables of change in specific impacts. 
A final problem presented by the existence of many types and degrees of impacts and impact groups requires the development of criteria by which comparisons of impacts may be made. If the impacts of a project are not distributed equally throughout a community, how will increased noise in one neighborhood be compared with increased employment for specific social groups (e.g., those in the construction trades)? The crucial problem in SIAs is the way in which dissimilar impacts are "weighted" or compared with one another. The approaches to this problem in each SIA will affect the way different impacts can be measured. In short, the crucial question is, "Who decides what is important when social groups are impacted differently?" (Wolf, 1974).

\subsubsection{Evaluating Impacts and Projects}

The final component of SIA involves evaluation of impacts and of the projects. The essential problem in evaluation is the problem of social equity: who decides the relative "goodness" of one project over the next? Moreover, how is that decision reached? Procedurally, evaluation must allow for diverse and of ten conflicting interests among impact groups. How can evaluations permit the widest possible participation and result in decisions that affect many social groups as equitably as possible? These questions frame the critical problems of the evaluation component of social impact assessment.

Often, conflict is regulated in assessment through the mechanism of controlled participation. Sponsoring agencies believe that public involvement in the assessment process will ensure participation of impact groups. Despite such public participation, others usually make the final decisions about the implications of a social impact assessment. As a result, conflict regulated through public participation mechanisms of ten reappears to plague decision makers as projects are about to be developed; programs, implemented; or policies, enacted. Such conflict is the outcome of disparate perceptions of social inequity. Conflict over social equity concerns can be mitigated by extending public participation throughout the decision-making process.

In conclusion, decision makers in the past have been shortsighted in their assessments of the impacts of energy technologies. Long-term, unanticipated, and unintended impacts have not been included. One approach that minimizes some of these problems involves life-cycle assessments. Life-cycle assessment refers to longitudinal investigations over the life of a project. Thinking in terms of the life cycle of a project reveals a more meaningful and comprehensive assessment oon-making process.

\subsection{ASSESSMENT STRATEGIES AND TECHNIQUES}

A variety of strategies and techniques have been used in social impact assessments. In part, that variety reflects the diversity in the projects assessed and the research orientations of the assessors.

As investigative tools, technology assessment and social assessment are equally science and art, in that they incorporate scientific principles of inquiry and the art of anticipating the future. Value judgments are part of human decision making. But, future value changes cannot be predicted. Unless technology and social assessments are acknowledged as arts of anticipation, decision makers will tend to reify their conclusions and to have erroneous expectations (Vlachos, 1977; Wolf, 1974). 
The various SIA strategies and techniques can be organized in two ways. One approach is to organize strategies and techniques by type of investigation; a second approach is to organize them by the research function they perform. Table 2-1 presents a general list of strategies and techniques.* Strategies and techniques can be organized first by type of assessment. Generally, social impact research uses descriptive techniques, and social forecasts use both descriptive and predictive techniques. The techniques listed in Table 2-1 apply to forecasts. Those that are primarily descriptive (e.g., checklists, matrices, IMPASSE, dialectical scanning, Delbecq technique, Delphi, project compar isons technique, and social profiling) apply to social impact research. Similarily, some research strategies are useful in social impact research and forecasts (e.g., cross-impact analysis, input-output analysis, survey research methods) whereas others are appropriate only for forecasts (e.g., social forecasting, simulation).

Table 2-1. TECHNIQUES, TYPES OF ANALYSIS, AND RESEARCH METHODOLOGIES BMPLOYED IN SIAS

\begin{tabular}{lll}
\hline \multicolumn{1}{c}{ Techniques } & Types of Analysis & Research Methodologies \\
\hline Checklists and Matrices & Cost-Benefit & Obser vational \\
IMPASSE & Cost-Effectiveness & Demographic \\
Dialectical Scanning & Input-Output & Matrix \\
Delbecg Technique & Sensitivity & Ethnographic \\
Delphi & Institutional & Archival Research \\
Scenarios & Social Network & Social Indicators \\
Surveys & Trend & Impact Monitoring \\
Simulation-Modeling & Multivariate & Computer Matrix \\
Project Comparisons Techniques & Risk & Social Forecasting \\
Social Profiling & Value & Social Graphics \\
Projcetion & Causal Modeling & Evaluation-R eseurch \\
& Simulation-Modeling & Psycholugicul Assessinent \\
& & Survey Research \\
& & Ethnomethodology
\end{tabular}

The second way to organize SIA strategies and techniques involves categnizing them according to their function in an assessment. For example, is a strategy or technique used for the purpose of research design (e.g., field experiment, survey), data gathering (e.g., observation), or analysis (e.g., multivariate analysis)? The selection of strategies and techniques for an assessment depends upon their compatibility with one another. In light of the complexity of the social context of SIAs, assessments incorporating numerous, complementary strategies and techniques produce the most meaningful and comprehensive social impact information (Wolf, 1974; Finsterbusch and Wolf, 1977; Helmer, 1977; Olsen and Merwin, 1977; Shields, 1977).

*See Wolf (1974), Runyan (1977), and Finsterbusch and Wolf (1977) for detailed descriptions of the SIA strategies and techniques listed in Table 2-1. 


\subsection{CRITICAL DISTINCTIONS BETWEEN ASSESSMENTS OF DECENTRALIZED SOLAR ENERGY PROJECTS AND CONVENTIONAL ENERGY PROJECTS}

An underlying methodological constraint in conducting assessments of solar energy projects is that few social impacts have been performed (Cambel, et al., 1978; DuffeyArmstrong, 1979; Milne, et al., 1979). Social impact studies of energy technologies have focused primarily on conventional-and, consequently, centralized-technologies. Although some aspects of assessments of conventional energy and solar energy projects may be similar, at least three critical distinctions exist. These distinctions are (1) the units of analysis of the assessment, (2) the shift in focus of the study, and (3) the differences in the scale of the technology.

\subsubsection{Units of Analysis}

This factor refers to the social levels that must be examined to identify impacts. In general, it is presumed that assessments would seek impacts at all levels of society (e.g., impacts on society, community, organizations, social groups, and individuals). SIAs of conventional energy projects have consistently investigated impacts only on the organization (e.g., businesses) and community (e.g., boom towns) levels rather than on the set of social units comprising society. Project impacts on organizations and community are important, but they represent only some of a project's social impacts. More meaningful assessments would investigate impacts at all levels of society. Important secondary impacts are frequently missed when this is not done.*

Emphasis on organization and community levels in assessments of conventional energy projects results from the centralized character of the projects. This characteristic has influenced the level of analysis and has constrained the assessment of impacts at socialgroup and individual levels. Primary social impacts were detected at the organization and community levels, but secondary impacts at the social-group and individual levels were rarely specified. All levels of society must be investigated for impacts in social impact assessments of solar energy projects. However, because of the generally decentralized nature of the technology, the primary emphasis would be on the individual, group, and community levels of analysis. Emphasis on these units is appropriate because most primary impacts will occur at these levels of society. Secondary impacts of solar energy projects are most likely to be detected at the community and societal levels. It is important to note that emphasis on these levels of society entails a significant reorientation in thinking about primary and secondary impacts of energy on society.

\subsubsection{Shift in Focus}

Assessments that present impacts drawn only from the levels of the organization and the community exhibit a deeper problem in social impact assessment. The problem is that

*Primary and secondary impacts are distinct from first-order and second-order impacts for the purposes of this report; primary and secondary refer to degree of importance of impacts, a determination that will vary with the identity of the person or group performing the assessment. Primary and secondary impacts of ten occur at different levels of society. First-order and second-order impacts, on the other hand, refer to direct and indirect impacts, respectively. Second-order impacts, for example, result from the interaction of first-order impacts with one another, with the project, or with other social phenomena. 
these levels of analysis place value on inf rastructure (e.g., public facilities like water and sewer systems) and public services (e.g., education and health care) but do not place value on people (e.g., workers, youth, retired persons, and the poor). While the orientation toward infrastructure has dominated social impact assessments of conventional energy systems, it is less useful and meaningful in assessments of decentralized solar energy projects, in which individuals and social groups are directly affected. Decentralized energy projects touch people directly and only indirectly touch community and society infrastructure. As a consequence, assessments of decentralized solar energy projects must focus on people and not on inf rastructure.

\subsubsection{Differences in Scale}

A third critical distinction is the difference in scale between centralized and decentralized energy oystems. The functions of production and consumption are separate in centralized energy systems. In decentralized energy systems, however, these functions generally are not differentiated. Centralized electricity facilities, for example, produce electricity for a large number of end users. Electricity is distributed from point of production to points of consumption through a grid system which may extend hundreds of miles. The role of the residential end user is limited strictly to that of consumer. The adoption of decentralized solar energy technologies in the residential sector, however, means a transformation of the private residence from energy consumption system to energy production and consumption system. Accordingly, decentralized energy production broadens the role of resident from solely energy consumer to both energy producer and consumer.

The difference in scale between centralized and decentralized energy systems suggests two essential differences in assessment strategies. First, impacts associated with a resident's double role as energy producer and consumer are not ascertainable in an assessment strategy that treats the resident solely as an energy consumer. That is, assessment strategies designed for centralized energy projects cannot address impacts on people when energy is produced and consumed in the home.

Second, primary and first-order impacts of centralized energy projects are often secondary and second-order impacts of decentralized energy projects, and vice versa. Firstorder social impacts of centralized energy projects generally occur at the level of the organization, community, or society, and are impacts on inf rastructure (e.g., impacts on transportation, industry, public services, education). In contrast, first-order impacts of decentralized energy projects occur at the individual, the social-group, and the organization levels, and are impacts on people (e.g., impacts on lifestyle, attitudes, energy consumption, and general consumer behavior). First-order impacts of decentralized energy projects in turn affect infrastructure. In this context, impacts on infrastructure are second-order impacts. Assessment strategies suitable for investigating the social impacts of decentralized energy projects are those designed to address first-order social impacts on individuals, social groups, and communities.

\subsection{THE NEED FOR MODIPIED APPROACHES TO ASSESSMENT}

Discussion of major distinctions between conventional and decentralized solar energy projects suggests that assessments of decentralized solar energy projects require a different. perspective. This perspective will place greatest emphasis on impacts on people rather than on infrastructure, and on the individual, group, and organization levels of 
analysis. The three major distinctions also suggest the need for new social impact categories and a new analytical framework to guide the assessment.

\subsubsection{New Impact Categories}

The problems of units of analysis, the shift in focus, and differences in scale are not separate problems to be solved independently. Instead, these problems interact. A new orientation toward people is critical in assessments of decentralized solar energy projects where primary impacts are impacts on people. Similarly, the primary units of analysis in assessments of decentralized solar applications will be the individual, social groups, and organizations.

Because of the shift in focus, the level of analysis, and differences in scale, new impact categories will be necessary. Impact categories related to infrastructure (e.g., public services) will need to be augmented by categories of impacts on people (e.g., autonomy in energy provision). Impact categories related to organizations (e.g., front-end costs and profit margins) and communities (e.g., tax revenues) will need to be augmented by categories of impacts on individuals (wages), social groups (employment), the nation (energy independence), and the international community (resource and environmental protection). To summarize, a general problem for social impact assessments of solar energy is the generation of new impact categories that are appropriate to assessments of decentralized energy project impacts on people at the individual, social-group, and organization levels.

\subsubsection{New Analytical Frameworks}

One implication of new impact categories is the need for new analytical frameworks. For example, two new impact categories for solar energy are public participation in community energy decision making and organization self-reliance and autonomy. Social impact assessments of conventional energy projects have not included analyses of these categories. The extent of these impacts may significantly alter or impinge upon the inf rastructure of communities. Some examples of second-order impacts on inf rastructure are population growth patterns and rates, employment/unemployment rates, and mill levy rates.* In this case, a framework or procedure for assessing the social impacts of solar energy technologies would include techniques for identifying and measuring increases in public participation, organization autonomy, and energy decision making.

In conclusion, a framework for assessing the social impacts of solar energy projects would include new impact categories of relevance to decentralized energy. The generation of appropriate impact categories and the development of applicable analytical frameworks are iterative and incremental processes. Consequently, these tasks can be expected to absorb much of the initial efforts of social impact assessments of solar energy projects.

*These are not far-fetched possibilities. Conservation of gasoline by motorists has recently altered production and refinery schedules, driven down the price of gas at the pumps, decreased petro-additives exported to OPEC nations, and forced many laborers who transport gasoline out of work. 
SEPI 


\section{SBCTION 3.0}

\section{STUDY APPROACH AND DESIGN}

\subsection{NTTRODUCTION}

This section describes the approach and design of the investigation. The objective of this investigation was to specify, at the national or societal level, the likely primary and secondary impacts of proposed policy initiatives upon people. The study approach was heavily influenced by the scope of the investigation as well as by the resource constraints of the project. The scope of the investigation, a national one, did not permit specification of impacts on identifiable social groups. Only general impacts could be reported. In addition, the time and resource constraints of the project did not permit primary data collection. So, information about social impacts had to be extracted or inferred from secondary data. These conditions formed the basis upon which the investigation was designed.

Several assumptions prefaced this investigation and helped specify the parameters of the st udy. First, the investigators assumed that the policy initiatives would have specifiable primary and secondary impacts. Second, they assumed that these impacts could be stated as general impacts at the national or societal level of analysis. The third assumption was that known impacts of energy technologies, including solar technologies, could serve as guides to the specification of likely future social impacts of proposed policies to promote solar energy use.

\subsection{STUDY APPROACH}

The study approach used an inductive strategy to identify and specify likely social impacts of the policy initiatives. The first step was to identify known impacts of energy and related technologies. These were organized into a set of social-impact categories by conceptual similarity. Next, the level of social impact and the solar energy technology associated with each impact were specified. Then, each policy initiative was assessed by systematically perusing the set of social-impact categories for likely salient effects of the initiative. Finally, the major findings of the investigation were induced from the salient social impacts.

\subsubsection{Selection of Proposed Policy Initiatives}

A wide range of federal programs that could increase solar energy use in the nation were grouped into three programmatic options representing three distinct levels of government support. The base-case option would continue existing programs but make them more effective. The practical case would expand current federal support with selected programs designed to achieve specific cost-effective objectives, and the high-priority option would substantially increase federal support through a variety of programs to achieve the national goal of accelerated use of solar energy. The practical case was chosen because of its potential to become the feasible course of government action.

The proposed national-level policy initiatives selected for study reflect an expansion of the current level of federal eff orts to accomplish specific energy production objectives. The criteria for selecting an initiative for study were that the initiative had to have been 
introduced as a bill in the 96th Congress, represent an expansion of an existing federal program, and accomplish cost-effective objectives. In addition, the set of selected initiatives had to reflect a pace of enactment and level of federal eff ort consistent with the achievement of the $15 \%$ to $20 \%$ solar energy use goal by the turn of the century. Also, as a set, the initiatives had to encourage solar energy use in four end-use sectors: residential/commercial buildings, industry, utilities, and government. Five policy initiatives are proposed for the residential/commercial sector, one initiative each for the industry and utility sectors, and two for the government sector.

\subsubsection{Identifying Known Impacts}

The first activity was to identify known impacts of energy and related technologies applicable to gaining an understanding of likely impacts of the development and deployment of solar' energy. 'This was accomplished by means of a review of social impact assessment literature. Literature topics included effects of siting central power plants (hydroelectric, coal, nuclear); boom town effects of mineral extraction and power plant construction; and siting of federal dams and highways. In addition, all SERI reports and available assessments of solar energy technologies were reviewed for social impacts. The resulting list became the basis for creating categories of social impacts.

The second activity was to formulate a set of categories by which to organize the social impacts. These social impact categories were identified inductively by noting concept ual similarities among them. The result was a state-of-knowledge catalogue of 14 categories gleaned from the list of social impacts:

1. Financial Aspects of Solar Energy Decision Making

2. Behavior Related to Solar Energy Use

3. Land-Use Impacts

4. Political Institutions Impacts

5. Impacts on the Economy

6. Inf ormation and Education Impacts

7. Social Acceptance

8. Consumer Demand/Protection Impacts

9. IIealth and Eafety Impacts

10. Employment Impacts

11. Aesthetics Imparts

12. Impacts on Industry

13. Quality of Life Impacts

14. International Implications

Each of these categories is briefly described and the sources of social impact information contributing to the category are referenced in Sec. 4.2, Categories of Sucial Impacts. 


\subsubsection{Levels of Social Impact}

The next step in the approach was to identify the level of social impacting and the solar energy technology associated with the known impacts. Society is composed of social elements: individuals, social groups, formal organizations, communities, and society (Broom and Selznick, 1978; Eitzen, 1978). These elements are described in the glossary. Policy initiatives, like the solar energy technologies they are designed to promote, aff ect society through its social elements. The impacts of the initiatives and technologies may be spread differently through society, affecting one, some, or all social elements. Investigators of social impacts must acknowledge these social elements as essential to understanding the dynamic interrelationship between technology and society. Distinguishing among social elements is important because a policy intended to influence one element of society may have unintended detrimental effects on other social elements. In this investigation, the levels of social impact analysis parallel the social elements and form an essential typology for understanding the impacts of the policy initiatives.

\subsubsection{Solar Energy Technologies}

Concomitant with the organization of social impacts into categories, the solar energy technologies associated with each impact were listed with the impact. The set of technologies included the decentralized technologies described and evaluated in other TASE work. The set is:

- Solar heating and cooling (SHAC): active space heating, domestic hot water, passive space heating for residential, commercial, and industrial buildings.

- Photovoltaics (PV): electricity for residential, commercial, and industrial buildings.

- Small wind energy conversion systems (SWECS): electricity.

- Biomass conversion (B): forest and agricultural products and residues for residential and commercial buildings and industrial by-products for industrial processes. (Industrial and agricultural process heat are considered to be processes rather than energy technologies.) .

Documenting social impacts by level of social impact and by technology helped point out gaps in our knowledge that need to be filled to investigate more fully the impacts of the policy initiatives. The categories also served as tools to begin questioning what the social impacts of the policy initiatives might be.

The state-of-knowledge catalogue of social impacts in Table 4-1, Sec. 4.0 is presented by both level of social impact and solar energy technology.

\subsubsection{Assessing Impects of Policy Initiatives}

In this step the policy initiatives were correlated with the social impacts listed by categories of impact. Each initiative was assessed independently by systematically perusing the set of social impact categories for likely salient effects. Impacts were identified by social level of impact and associated solar energy technology. In addition, primary and 
secondary impacts* were specified. Gaps in our knowledge about likely impacts are reflected in questions. Also, those impacts affecting more than one social level were identified with the social levels by writing the statement of impact across the columns. The likely social impacts of each initiative are presented in Tables 5-1 through 5-9.

\subsubsection{Case Application: The Rental Housing Market}

This step was taken to demonstrate the importance of disaggregating generalized social impacts at the national or societal level. By identifying specific groups of people, in this case the set of social groups constituting the residential rental market, the impacts of the relevant policy initiatives become specific and realistic effects. The social impacts presented in Tables 6-1 through 6-9 are more precise and realistic indications of how the initiatives will affect people.

\subsubsection{Formulating Recommendations}

The final step in the approach was to induce from the salient social impacts of each policy initiative recommendations for DOE action to accelerate solar energy use. This was done by gleaning the most crucial impacts from each initiative for each of the four enduse sectors: residential/comm ercial buildings, industry, utilities, and government. The implications of these impacts were generalized in terms of how DOE might relate to other federal agencies or take an active role in the implementation of each policy initiative. These recommendations are presented in Sec. 1.3 of this report.

In Sec. 5.0, the likely generalized social impacts of each of the nine policy initiatives are presented. And in Sec. 6.0, the impacts of the initiatives on the social groups that make up the rental housing market are presented.

*Primary impacts are first-order, direct, intended effects of the initiative; secondary impacts are second-order, indirect, unintended eff ects. 


\section{SECTION 4.0}

\section{SOCIAL IMPACTS}

Essential to this investigation are the definition of a social impact and the organization of an abundant and diverse literature about effects of energy technologies on society. This section presents material important to understanding what the investigators sought to identify as salient social impacts of proposed public policy initiatives to encourage the use of solar energy. Social impacts are defined, a technique for categorizing impacts is discussed, and 14 categories of impacts are presented that both summarize and organize the impacts literature reviewed for this study.

\subsection{DEPINING SOCIAL IMPACTS}

The social effects of introducing a new technology into society as an idea, prototype, or commercial application involve alterations of existing patterns of interaction and the formation of new patterns. Technologies affect individuals, groups, organizations, communities, institutions, and society separately, collectively, or in some subset. Social effects or impacts refer to the changes in the organization or activities of society that occur in conjunction with the technology (Olsen and Merwin, 1977). While there is no established, standard definition of a social impact, in this study it refers to a change in the organization or activities of society as well as to the social phenomena that undergo change. For instance, the need to conserve energy has had a collective effect on the people of our society as well as on society's organization and activities in energy-related matters. Social effects or impacts of the need to conserve energy include the federal and state income tax credits for the purchase and installation of energy conservation materials.

As we noted, social impacts tend to be both dynamic and complex-dynamic because society and its components are always changing and complex because the type and point of impact tend, to be multiple rather than singular. Rarely is the point of an impact of a technology only a community. It usually affects individuals and social groups as well. And, there are many types of social effects or impacts.

The effects of technologies, policies, or programs on people may be beneficial (e.g., employment opportunities) or adverse (e.g., unemployment). Similarly, the social impacts may be intended (e.g., job creation) or unintended (e.g., employment dislocation),

direct (e.g., local job opportunities) or indirect (e.g., mandatory relocation). They may be evident immediately or only after some delay. They may be desirable or undesirable (Olsen and Merwin, 1977), real or illusory. In this study, the social impacts to be identified would occur as a consequence of implementing each of nine proposed national-level public policy initiatives to accelerate the use of solar energy.

\subsection{CATEGORIES OF SOCIAL IMPACTS}

The growth of social-impact studies continues to be rapid, although few have been done of solar energy technologies (Cambel, et al., 1978; Duffey-Armstrong and Armstrong, 1979; Milne, et al., 1979). Most social-impact studies have concerned conventional energy resource and technology development, such as mineral extraction or the siting of power plants. The information provided by these studies is not usually complementary 
because of the case study methods used, nor is it comprehensive because of the short duration and focus of the studies. However, these studies do suggest to investigators of renewable energy technologies some general energy-related areas of potential social impacts.

The social-impacts literature was reviewed to identify known impacts of energy technologies development that would be applicable to the development of solar energy. In addition, available assessments and studies of solar energy technologies were reviewed for impacts. The diversity of the findings presented a challenging problem of organizing and presenting the information so it would be useful. In addition to those identified in the literature, impacts were added by positing the likely effects of solar technologies on society and on its components.

The list of identified social impacts was organized into categories according to the conceptual similarities exhibited among the impacts themselves. This inductive strategy, as we noted, resulted in 14 categories of conceptually similar impacts. In the following paragraphs, each of the 14 categories is described briefly and sources of social-impact information contributing to each category are referenced. 'Table 4-1 presents all the social-impact information from the literature review organized by categories of conceptual similarity. The 14 categories are not ordered by any criteria but are presented as a composite of categories derived from the literature. These categories of social impacts became our raw data file of known social impacts to which we would turn when we began to investigate the likely impacts of each policy initiative.

\subsubsection{Financial Aspects of Solar Energy Decision Making}

This category includes the impacts of financial factors in decision making about solar energy. It is composed of three subcategories: financial issues in consumer decision making, issues influencing decisions of financial institutions, and considerations of relevance to national-level financial policies. In Table 4-1, category 1 shows specific impacts drawn from the literature referenced below or identified by the study investigators.

References: Ashworth, et al., 1979; Berkman and Viscusi, 1973; Boulding, 1974; Cose, 1979; Duffey-Armstrong and Armstrong, 1979; Edesess, 1979; Ferrey, 1978; Hayes, 1978; Hyatt, 1979; Peelle, 1980; SRI, 1977; Roessner, et al., 1980; Vories and Strong, 1980.

\subsubsection{Behavior Related to Solar Bnergy Use}

The impacts in this category describe likely changes in the patterns of people's activities related to use of solar energy technologies. Some of these impacts describe the patterns of activities of occupants of solar-conditioned buildings; others describe more universal impacts. In Table 4-1, category 2 presents the impacts found in the literature cited below.

References: Duff ey-Armstrong and Armstrong, 1979; Franta, 1979; Holloway, 1979; Landsberg, 1974; Milne, et al., 1979; OToole, 1976; Peelle, 1980; Reader, 1979; RERC, 1980. 


\subsubsection{Land-Use Impacts}

This category includes land-use impacts discussed in the literature. These impacts are presented in two subcategories. One subcategory describes community-level regulatory strategies of land-use planning; the other identifies general land-use impacts relevant to policy planning for solar technologies. Specific impacts of this category appear in category 3 of Table 4-1.

References: Duffey-Armstrong and Armstrong, 1979; Ferrey, 1978; Messing, et al., 1979; Peelle, 1978; Ramsay and Cecelski, 1980; Schwab, 1979; Spivak, 1979; SRI, 1977; Twiss, et al., 1979.

\subsubsection{Political Institutions Impacts}

The SIA literature includes numerous references to political and institutional implications of energy and solar energy development and commercialization. In this category, political institutional impacts can be either on political institutions (to aff ect those institutions); or they can be impacts of existing political institutions on ideas, practices, or organizations related to solar energy. In Table 4-1, category 4 presents specific impacts found in the literature referenced below.

References: Bell, 1973; Christakis, 1979; Cook, 1979; Duffey-Armstrong and Armstrong, 1979; Ferrey, 1978; Hayes, 1977; McEvoy and Drietz, 1977; Messing, et al., 1979; Milne, et al., 1979; Ramsay and Cecelski, 1980; SRI, 1977; Tuve, 1976; Twiss, et al., 1979.

\subsubsection{Impacts on the Economy}

This category of impacts is restricted to those general economic impacts discussed frequently in the literature. The TASE project includes an economic assessment that is therefore the appropriate source of information about economic effects of solar energy technologies. Specific impacts are presented in category 5 of Table 4-1.

Rcfcrences: Belassa and Nelson, 1977; Bennington, 1978; Cose, 1979; Department of Energy, 1980; Mason, 1978; O'Toole, 1976; Ramsay and Cecelski, 1980; Vories and Strong, 1980.

\subsubsection{Information and Education Impacts}

The impacts in this category refer to the dissemination of information about solar energy technologies and applications through both formal and informal channels. Category 6 of Table $4=1$ presents specifio impact information drawn from the literature referenced below or identified by the study investigators.

References: Annual Review of Solar Energy for 1977, 1978; Duff ey-Armstrong and Armstrong, 1979; Farhar, et al., 1979; Franta, 1979; Hyatt, 1979; Ramsay and Cecelski, 1980; Sullivan, et al., 1979; Weis, 1978, 1979. 


\subsubsection{Social Acceptance}

This category includes the set of conditions and factors that give credibility to solar energy technologies and applications as valuable sources of usable energy. The category is subdivided into four components: value judgments about energy, economic motives, appropriate technologies, and barriers to acceptance. Category 7 of Table 4-1 presents the specific impact information for each component.

Ref erences: Ashworth, et al., 1979; Burns, et al., 1980; Commoner, et al., 1975; Farhar, et al., 1979; Messing, et al., 1979; Miles, 1976; Milne, et al., 1979; McEvoy and Drietz, 1977; Peelle, 1980; Ramsay and Cecelski, 1980; Reader, 1979; Thayer, 1978; Unseld and Crews, 1979; Young, 1973.

\subsubsection{Consumer Demand/Protection Impacts}

The impacts identified in this category summarize some of the concerns expressed in the literature about the energy demands of consumers and the need to protect persons working on and purchasing solar energy technologies. The impacts are presented as consumer demand or consumer protection impacts. Specific impact information is presented in category 8 of Table 4-1.

References: Ashworth, et al., 1979; Holloway, 1979; Ramsay, 1980; RERC, 1980; SEAL, 1979; Sullivan, et al., 1979; Vories and Strong, 1980; Weis, 1978.

\subsubsection{Health and Safety Impacts}

Health and safety effects of solar energy technologies are of major environmental and social concern in the development of solar energy technologies. The impacts identified here represent the range and detail of that concern in the SIA literature. Specific impact information drawn from the references citcd below is presented in cutegory 9 of Table 4-1.

References: Cambel, et al., 1978; Commoner, et al., 1975; Department of Energy, 1980; Huevelmans, 1974; Lawrence, 1979; Noun, 1979; Peelle, 1980; Ramsay and Cecelski, 1980; Smith, et al., 1974; SRI, 1977; Sullivan, et al., 1979; Vories and Strong, 1980.

\subsubsection{Employment Impacts}

This category of impacts represents a major theme in the SIA literature and has been offered as a crucial selling point for solar energy technologies in the energy development debate. The category is composed of three components: prospects for employment in the solar industry, vocational training for solar-related jobs, and economic/labor impacts. Category 10 of Table 4-1 presents impacts found in the literature referenced below.

References: Annual Review of Solar Energy for 1977, 1978; Burns, et al., 1980; Cose, 1979; Ferrey, 1978; Hayes, 1978; Holloway, 1979; Livingston, 1979; Lovins, 1976; Mason, 1978; McEvoy and Drietz, 1977; Ostendorf, 1980; OToole, 1976; Peelle, 1980; Solar Energy in Review, 1979; Sullivan, et al., 1979; Tuve, 1976. 


\subsubsection{Aesthetic Impacts}

Impacts in this category summarize a variety of concerns presented in the literature pertaining to the sensory perceptions of solar energy installations. Specific impacts from the literature cited below are presented in category 11 of Table 4-1.

References: Cambel, et al., 1978; Cook, 1978; Franta, 1979; Lawrence, et al., 1980; Miles, 1976; Milne, et al., 1979; Peelle, 1980; RERC, 1980; Spivak, 1979; Solar Energy in Review, 1979; Thayer, 1978.

\subsubsection{Impacts on Industry}

This category includes the effects of solar energy development and use on the industrial sector of society. The category is divided into impacts on the energy industry in general, the solar energy industry, nonenergy industry, and agricultural industry. The impacts on industry are categorized in Table 4-1 by composition, operation, and management sector.

References: Burns, et al., 1980; Cose, 1979; Department of Energy, 1980; Green, 1979; Hayes, 1977; Healy, 1976; Holloway, 1979; Katz, 1971; Messing, et al., 1979; OToole, 1976; Ramsay and Cecelski, 1980; Roessner, et al., 1980; Solar Energy in Review, 1979; Smith, 1980; SRI, 1977; Sullivan, et al., 1979; Unseld and Crews, 1980; Vories and Strong, 1980.

\subsubsection{Quality of Life Impacts}

This category of impacts is also a major theme in the SIA literature and concerns a set of individual and group satisfaction factors in a variety of life domains. This category is divided into several components of the set of quality of life indicators. The components are environmental quality, social values and preferences, personal factors, changes in social relationships, employment, community cohesion, equity, and sense of security. Impact information from the literature referenced below is presented in category 13 of Table 4-1.

References: Annual Review of Solar Energy for 1977, 1978; Bell, 1973; Campbell, et ul., 1976; Commoner, et al., 1975; Cóngdon, 1977; Cose, 1979; Ferrey, 1978; Freeman, 1974; French, 1977; Henderson, 1978; Holloway, 1979; Ilich, 1974; Landsberg, 1974; Lovins, 1976, 1978; McEvoy and Drietz, 1977; Messing, et al., 1979; Miles, 1976; Milne, et al., 1979; Ostendorf, 1980; OToole, 1976; Peelle, 1980; Ramsay and Cecelski, 1980; Solar Energy in Review, 1979; Schaller, 1979; Tuve, 1976; Twiss, et al., 1979; Unseld and Crews, 1980.

\subsubsection{International Implications}

The final category of social impacts induced from the SIA literature concerns the relationship between the development and application of solar energy technologies in the United States and the world community. Specific impact information from the literature listed below is presented in category 14 of Table 4-1.

Refcrences: Annual Review of Solar Energy for 1977, 1978; Bell, 1973; Congdon, 1977; Ehrlich, et al., 1973; Hayes, 1977; Illich, 1974; Lovins, 1974; Messing, et al., 1979; OToole, 1976; Rogers, 1976; Tuve, 1976. 
Table 4-1. SOCIAL IMPACTS OP ENERGY TECHNOLOGIES

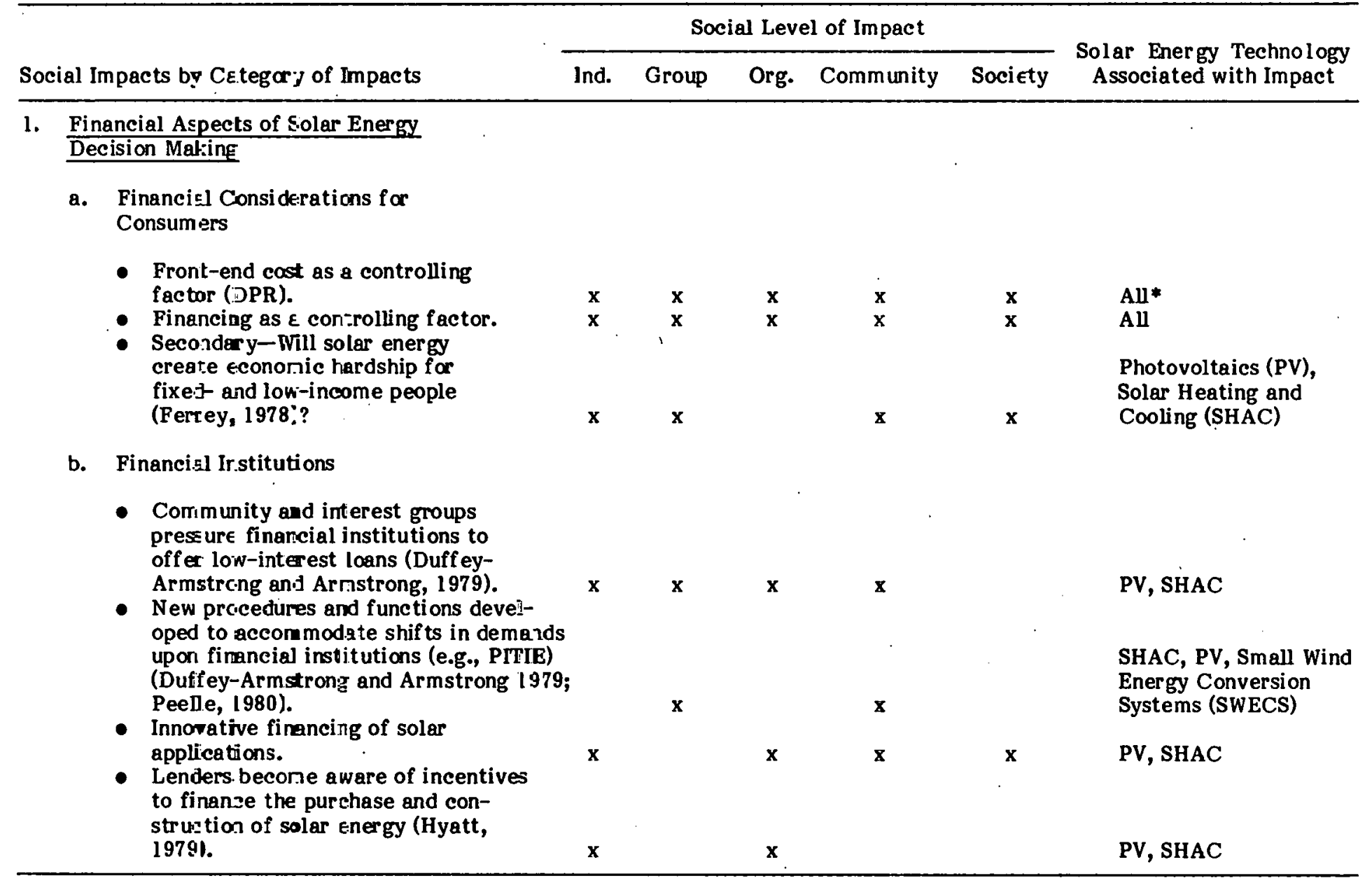

*All means the four solar enegy technologies: solar heating and cooling, photovoltaics, small wind energy conversion systems, and biomass. An " $\mathrm{k}$ " under an element of the social level of impact means that the social impast affects that component of society. The five compor.ents of social level of impact are defined in the glossary. 
Table 4-1. SOCIAL IMPACTS OP ENERGY TBCHNOLOGIES (Continued)

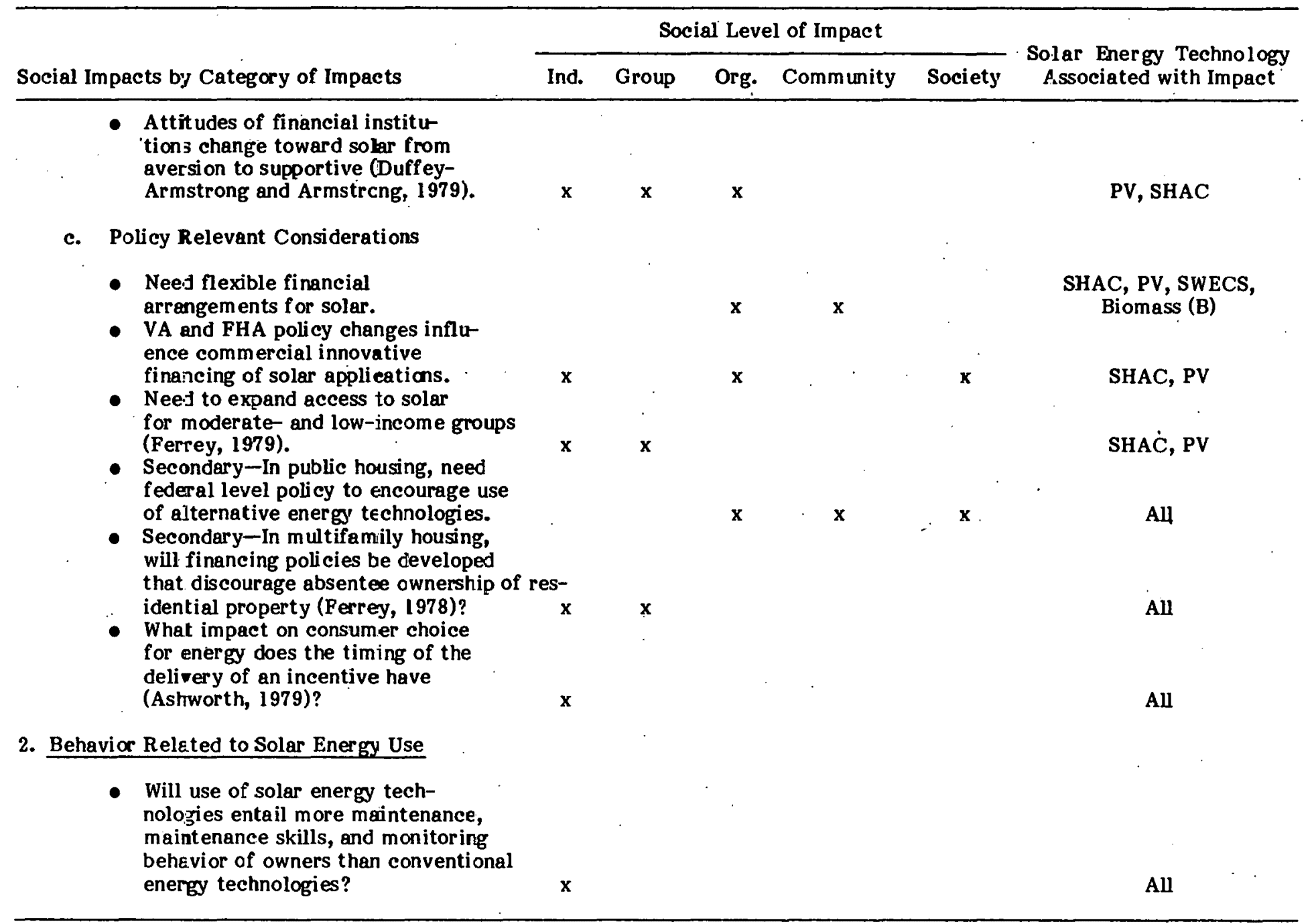


Table 4-1. SOCIAL IMPACTS OP BNERGY TECHNOLOGIES (Continued)

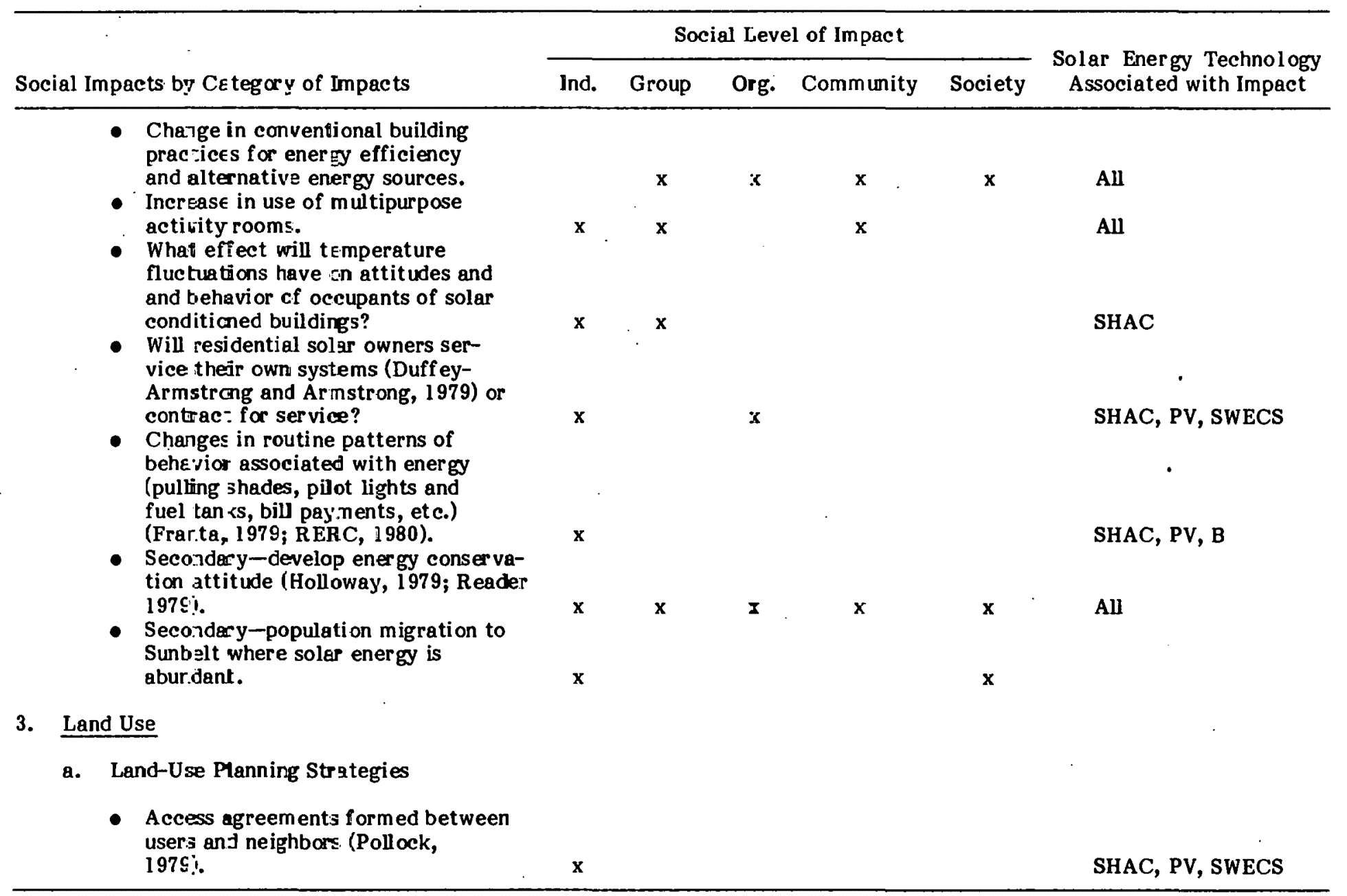


Table 4-1. SOCIAL IMPACTS OP ENERGY TECHNOLOGIES (Continued)

\begin{tabular}{|c|c|c|c|c|c|c|c|}
\hline \multirow{2}{*}{\multicolumn{2}{|c|}{ Social Impacts by Categary of Impacts }} & \multicolumn{5}{|c|}{ Social Level of Impact } & \multirow{2}{*}{$\begin{array}{l}\text { Solar Energy Technology } \\
\text { Associated with Impact }\end{array}$} \\
\hline & & Ind. & Group & Org. & Community & Society & \\
\hline b. & $\begin{array}{l}\text { Regional and community access } \\
\text { agreements established [e.g., solar, } \\
\text { wind easements (Pollock, 1979)]. } \\
\text { Change in building codes to permit } \\
\text { alternative energy technologies. } \\
\text { What trade-off criteria should be } \\
\text { established to determine use of land } \\
\text { among competing usəs? } \\
\text { What land-use disputes (zoning, health } \\
\text { and saf ety, environment) arise in con- } \\
\text { junction with siting and operation of } \\
\text { solar energy technologies? } \\
\text { What jurisdictional disputes (access to } \\
\text { resources, solid waste, pollutants) will } \\
\text { arise in conjunction with siting and } \\
\text { operation of solar eriergy technologies? } \\
\text { General Land Use } \\
\text { - } \\
\text { Decentralized energy systems require } \\
\text { decentralized land-use planning } \\
\text { (Messing, Friesema, and Morrell, 1979). } \\
\text { Increased development on slopes } \\
\text { with south orientati.ms and decreased } \\
\text { on slopes with north orientation. } \\
\text { Federal (Forest Service, BLM) policies } \\
\text { on availability of public lands for } \\
\text { timber harvesting aff ect avail- } \\
\text { ability of forest projucts and } \\
\text { residues for wood biomass (Schwab, } \\
\text { 1979). } \\
\text { Within existing urbanized areas, will } \\
\text { there be sufficient solar access to } \\
\text { meet total energy demand? }\end{array}$ & $\mathbf{x}$ & $\mathbf{x}$ & $\mathbf{x}$ & $\begin{array}{l}\mathbf{x} \\
\mathbf{x}\end{array}$ & $\mathbf{x}$ & $\begin{array}{l}\text { SHAC, PV, SWECS } \\
\text { All } \\
\text { SWECS, B } \\
\text { SWECS, B } \\
\text { SWECS, B }\end{array}$ \\
\hline
\end{tabular}


Table 4-1. SOCIAL IMPACTS OP ENERGY TECHNOLOGIES (Continued)

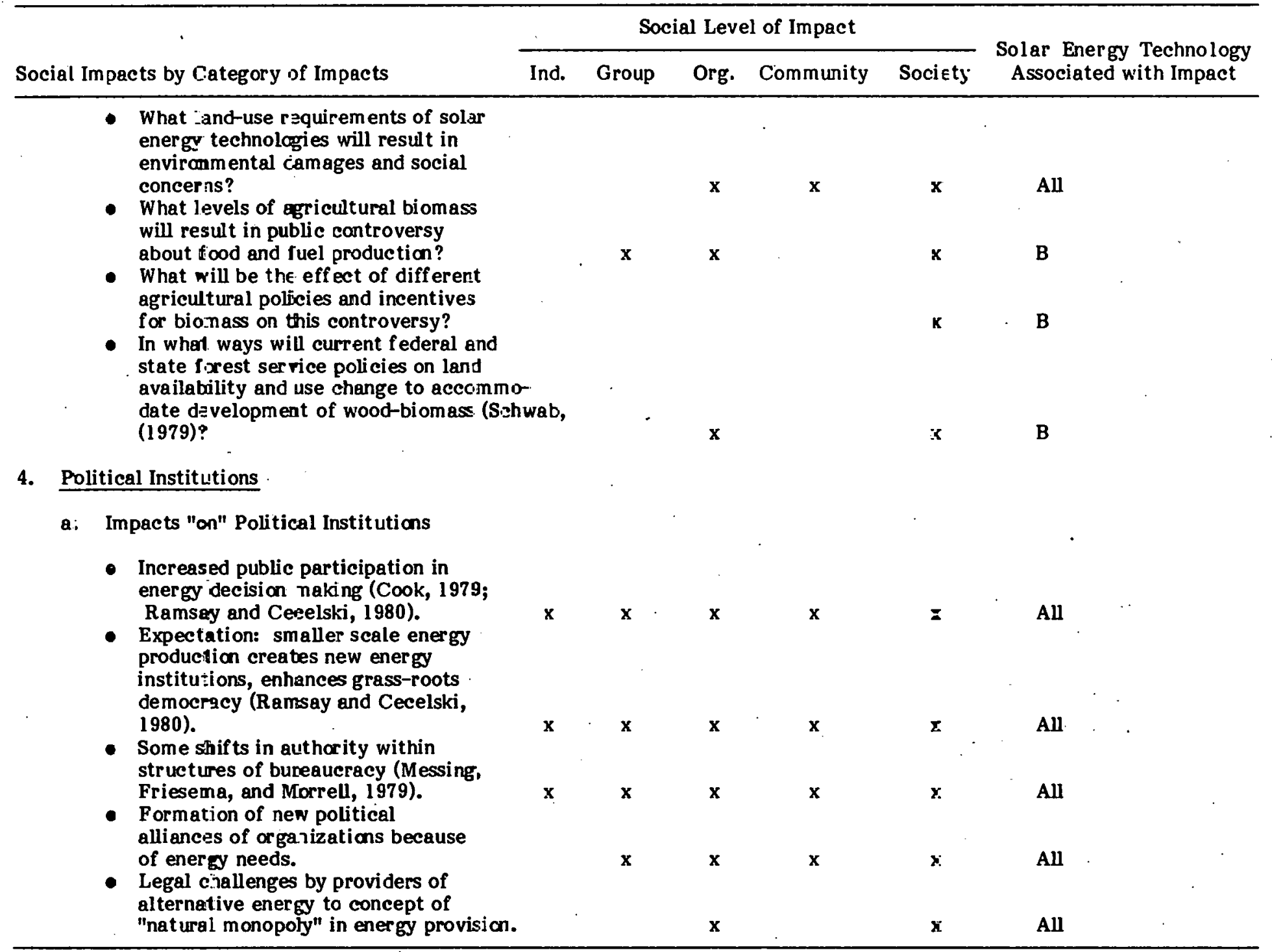


Table 4-1. SOCIAL IMPACTS OP ENERGY TECHNOLOGIRS (Continued)

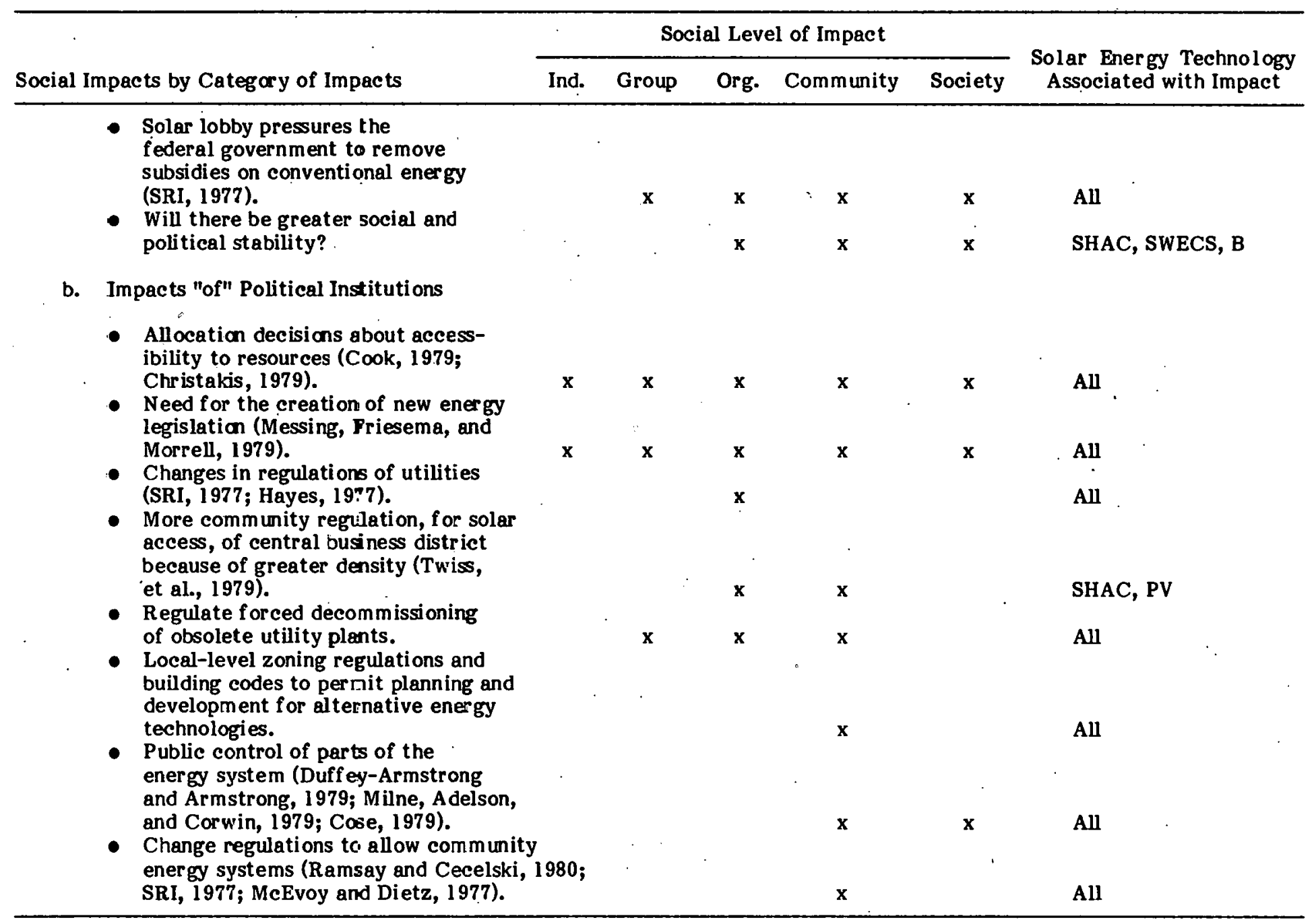


Table 4-1. SOCIAL IMPACTS OF ENERGY TECHNOLOGIES (Continued)

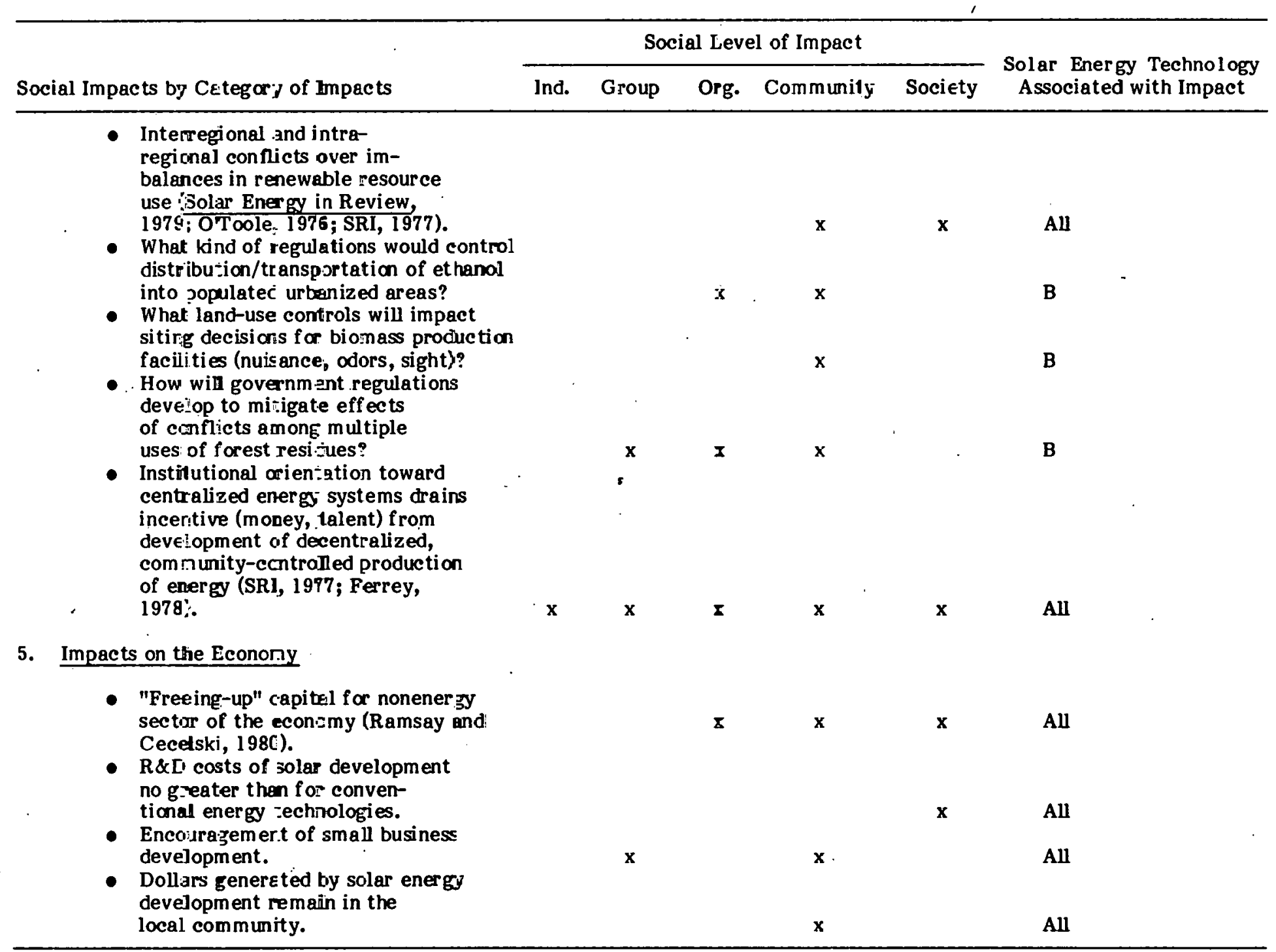


Table 4-1. SOCIAL IMPACTS OF ENERGY TECHNOLOGIES (Continued)

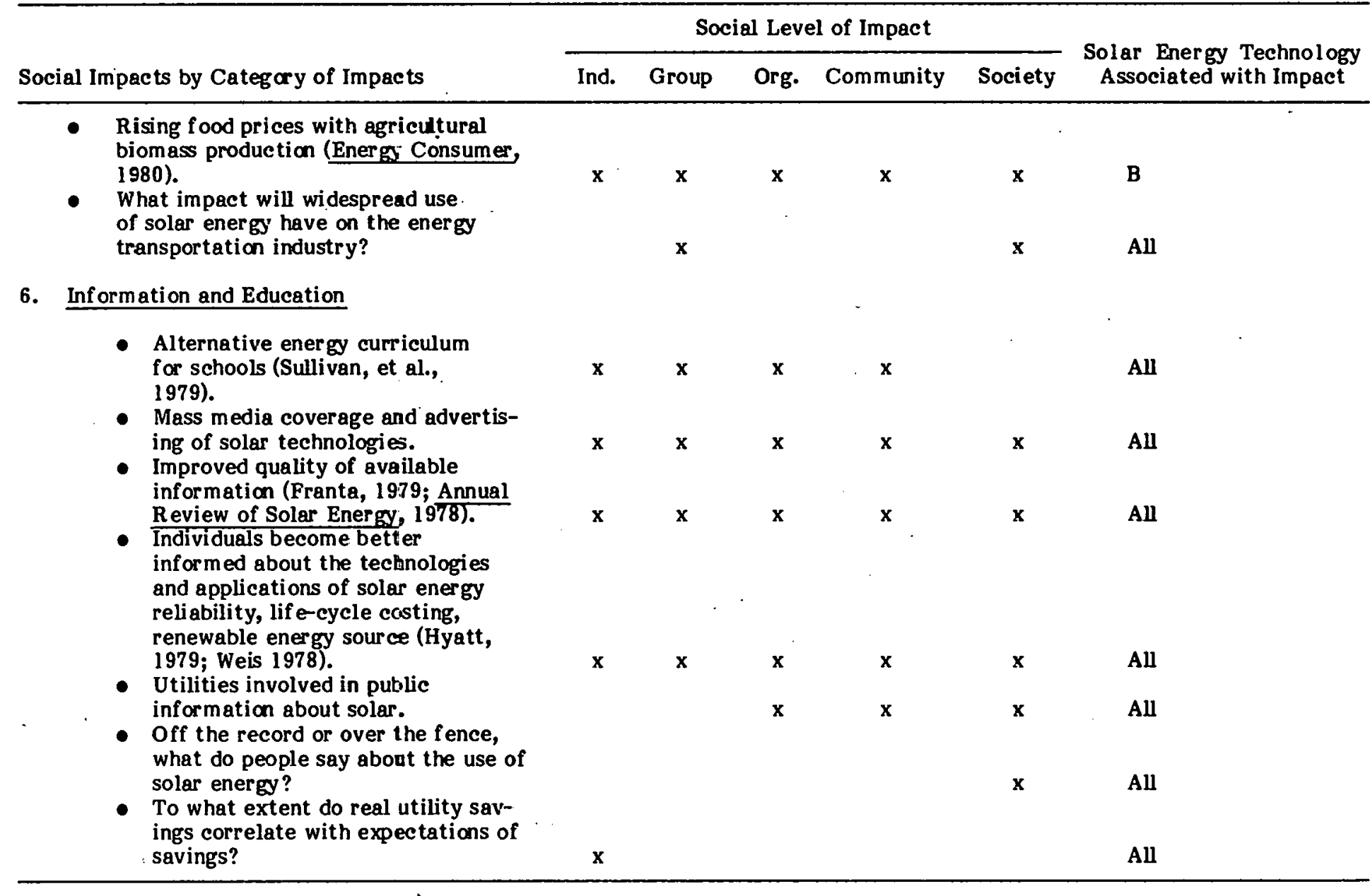


Table 4-1. SOCIAL IMPACTS OF ENERGY TECHNOLOGIES (Continued)

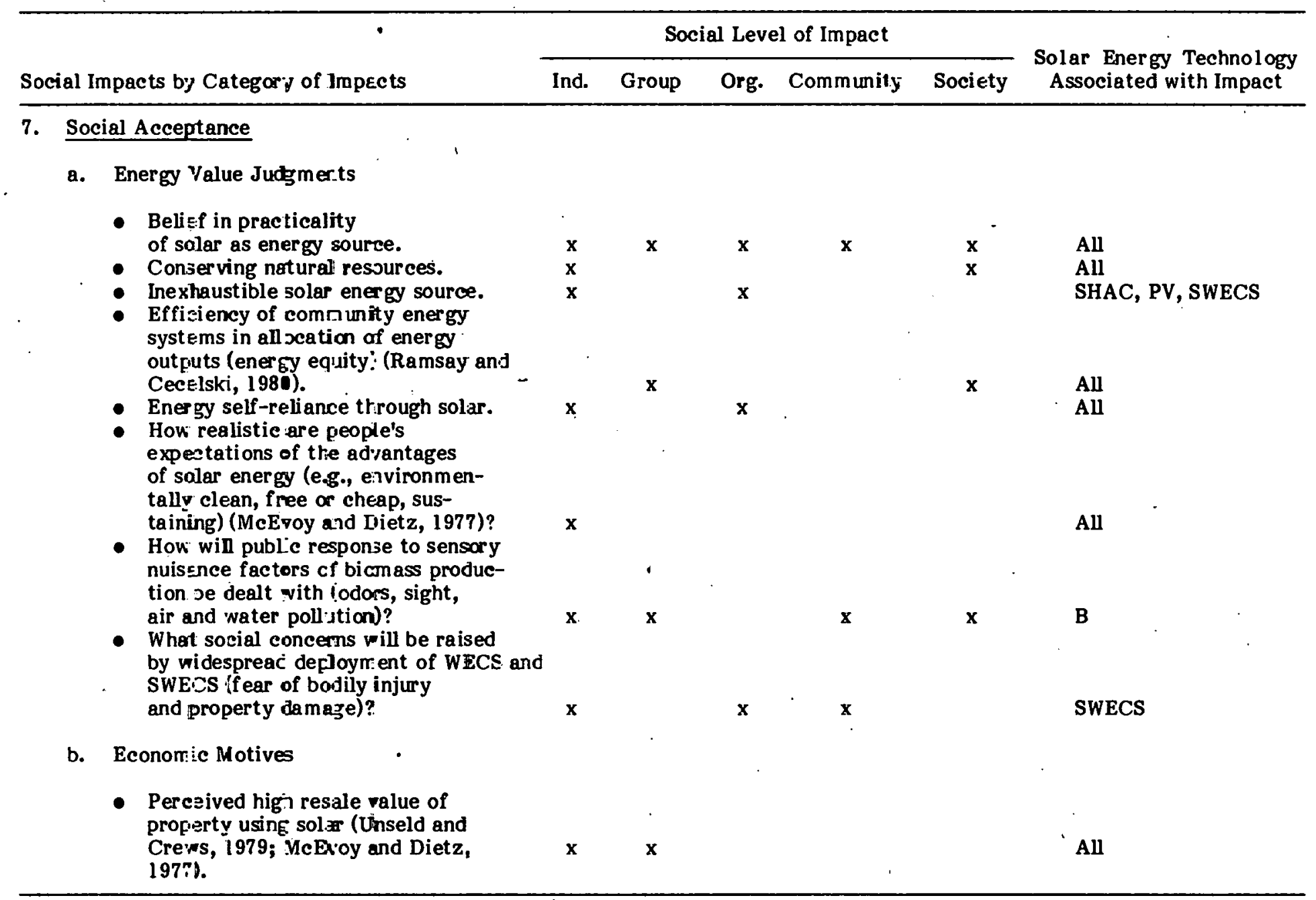

taining) (McEvoy and Dietz, 1977)?

will puble response to sensory

Wroducir and water poll'stion)? WECS (f ear of bodily injury and property damaje)? 197\%). 
Täble 4-1. SOCIAL IMPACTS OP ENERGY TECHNOLOGIES (Continued)

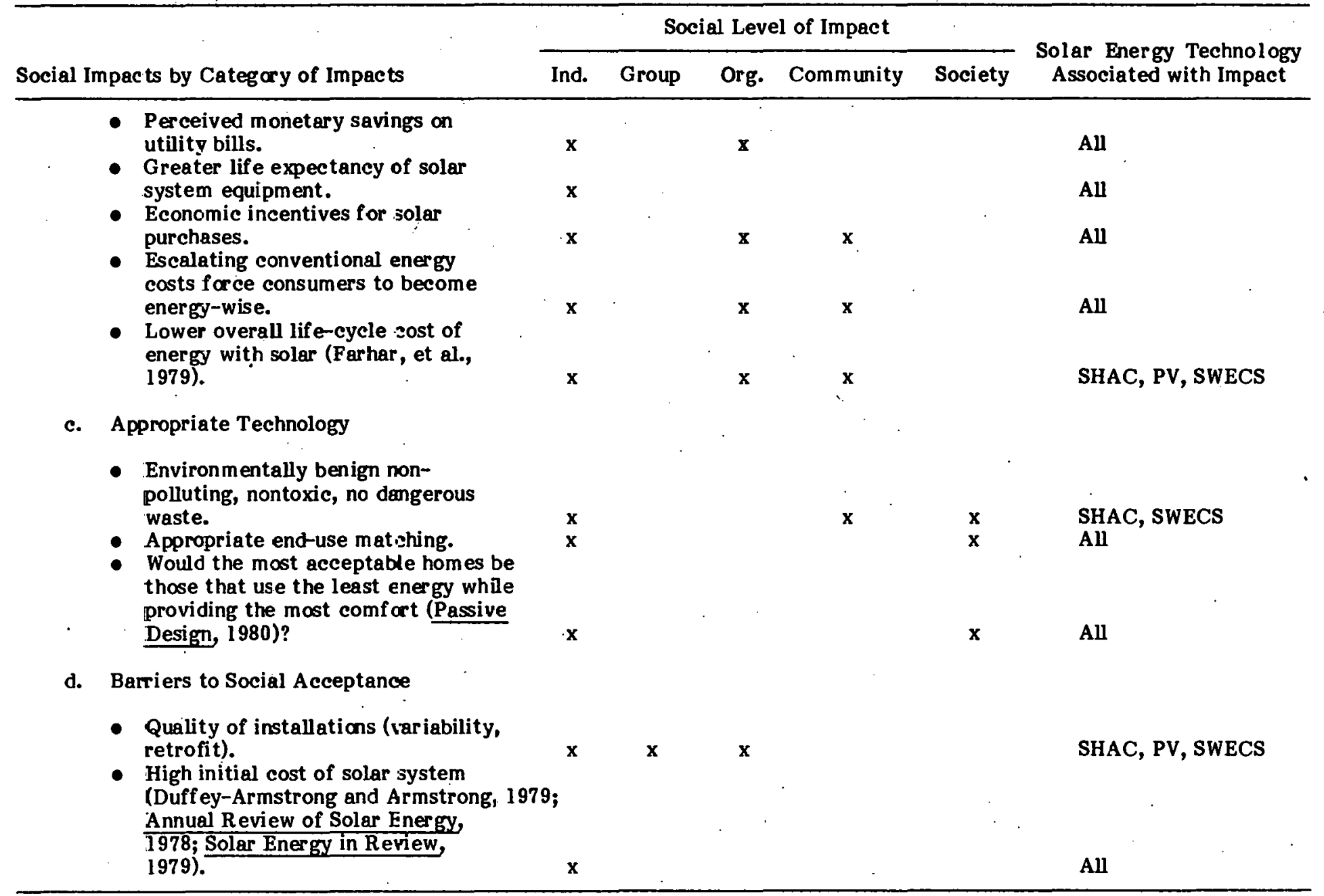

- Perceived monetary savings on system equipment.

Escalating conventional energy eneroy with solar (Farhar, et al.,

Appropriate Technology polluting, nontoxic, no dangerous

Appropriate enc-use mat.ahing. those that use the least energy whil providing the most comf art (Passive Design, 1980)? 
Table 4-1. SOCIAL IMPACTS OF ENERGY TBCHNOLOGIES (Continued)

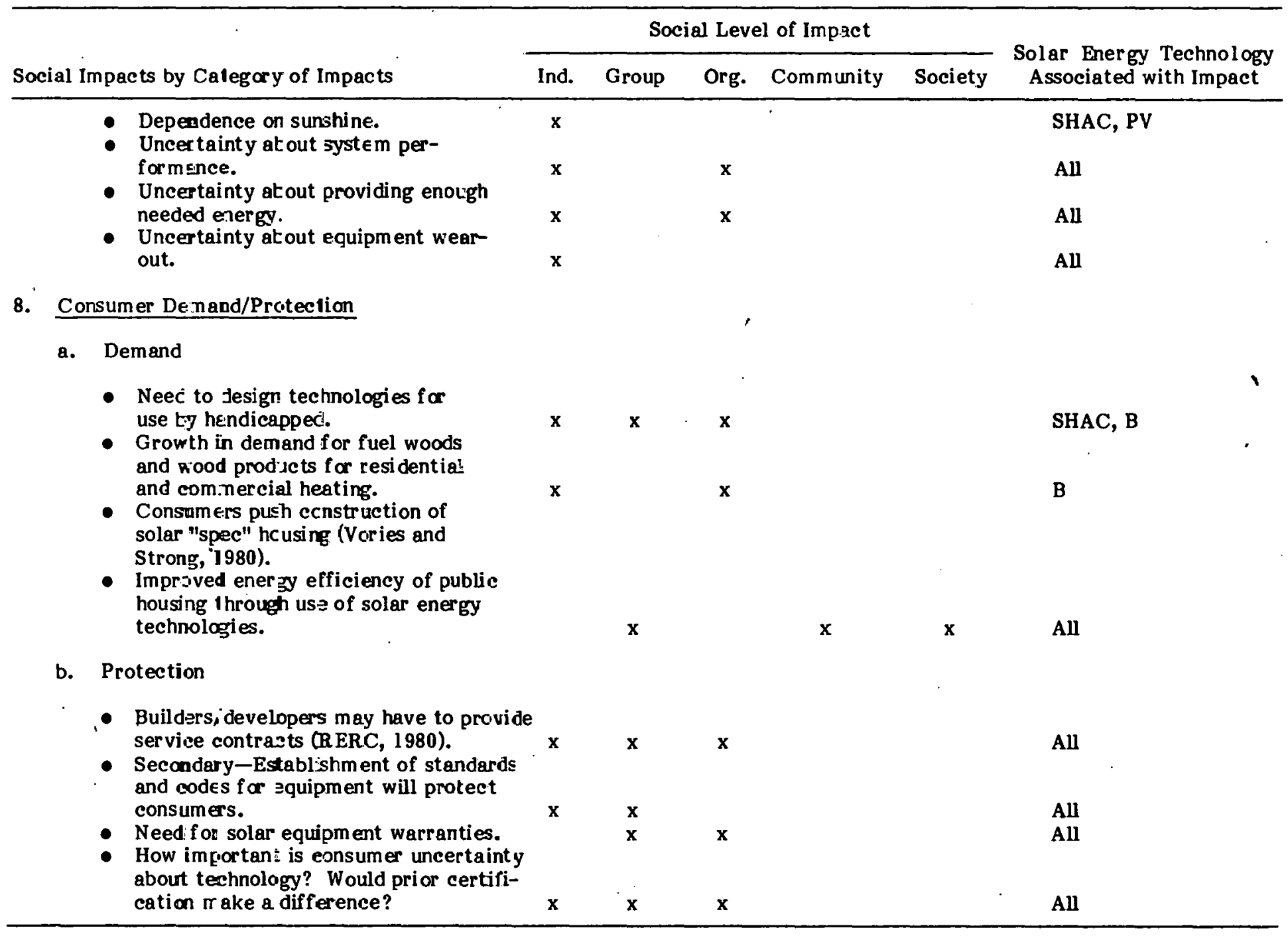


Table 4-1. SOCIAL IMPACTS OF ENRRGY TECHNOLOGISS (Continued)

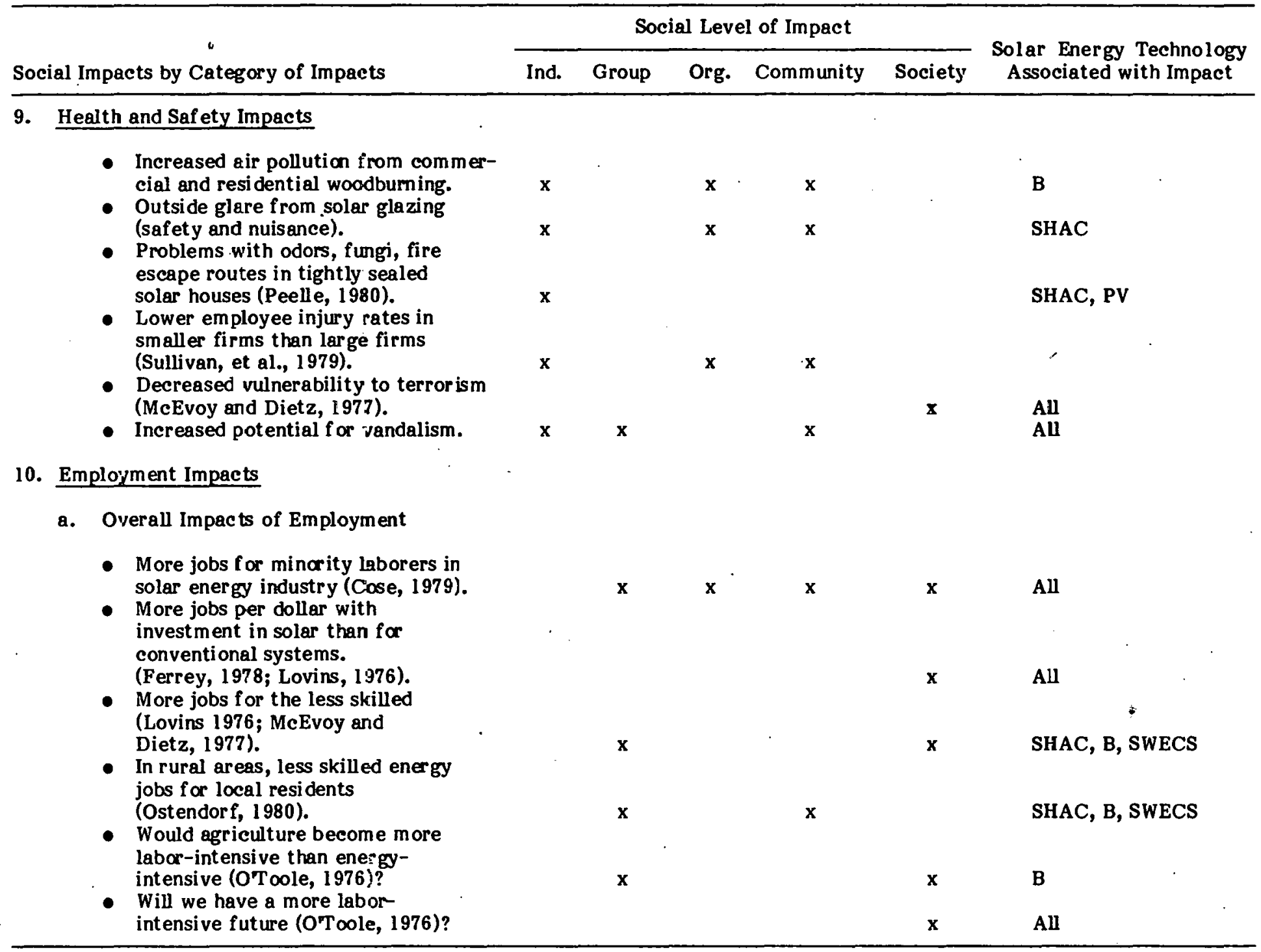


Table 4-1. SOCIAL IMPACTS OP ENERGY TECHNOLOGIES (Continued)

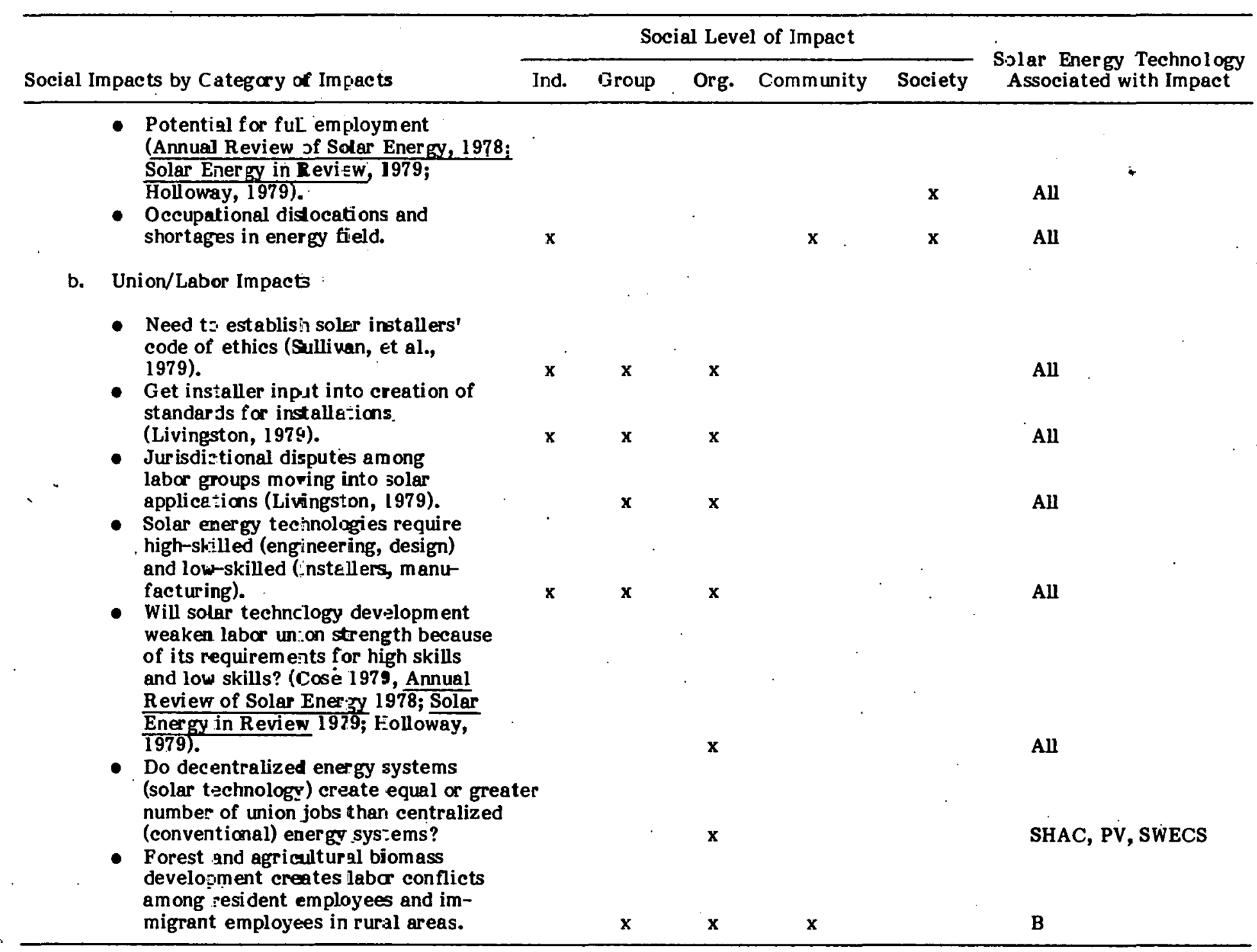


Table.4-1. SOCIAL IMPACTS OP ENERGY TBCHNOLOGIES (Continued)

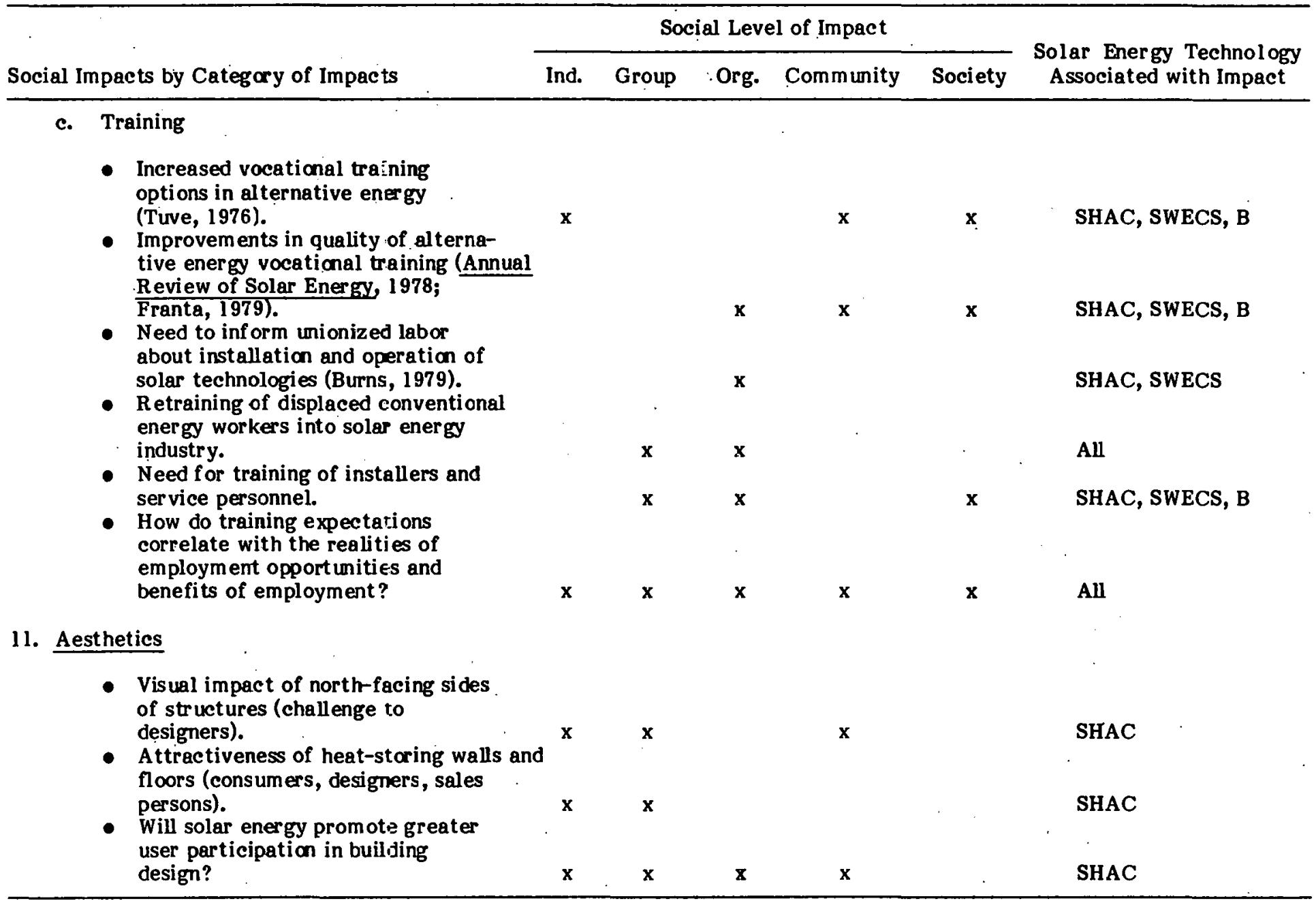


Table 4-1. SOCIAL IMPACTS OP ENERGY TECHNOLOGIES (Continued)

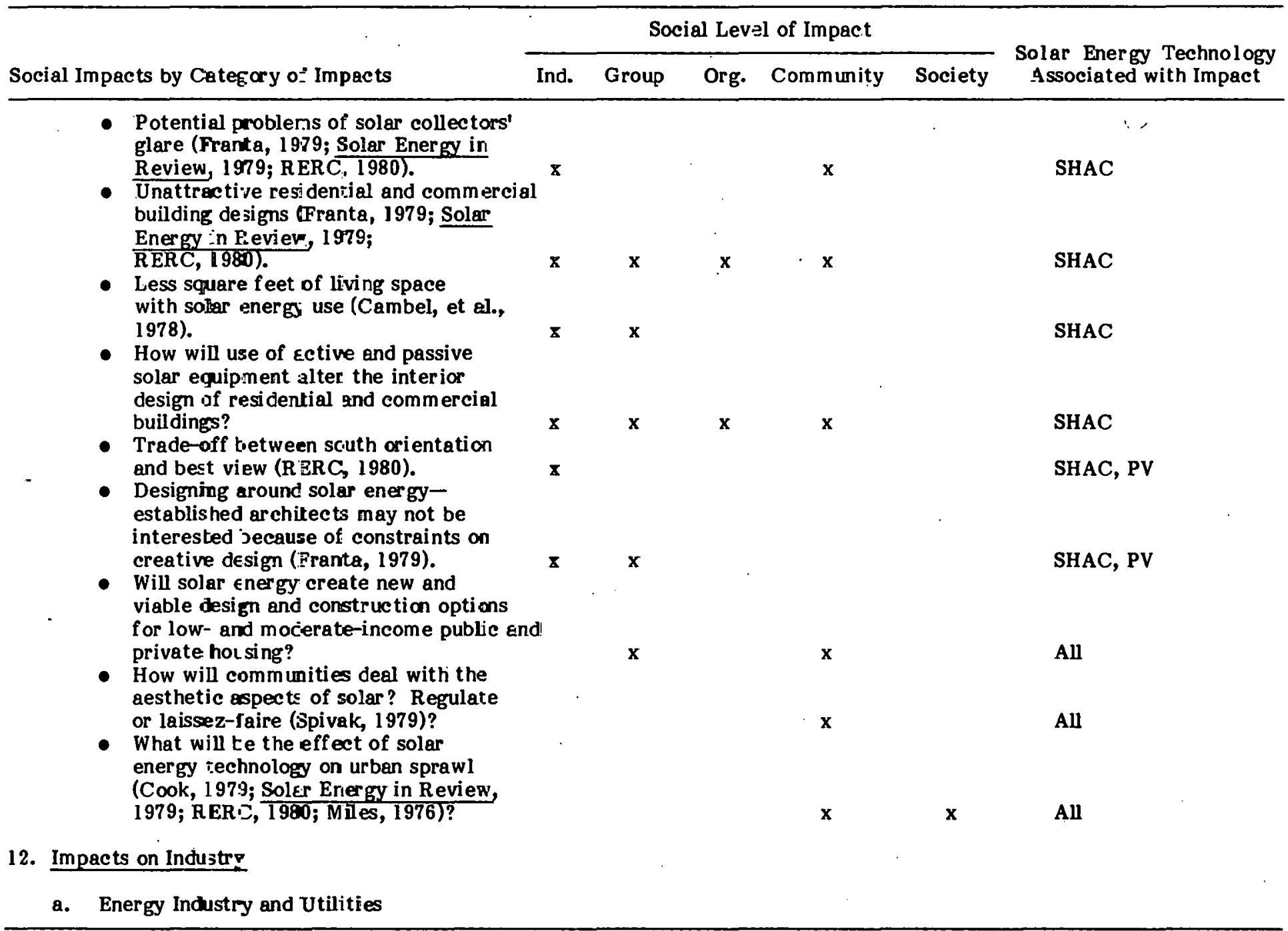


Table 4-1. SOCIAL IMPACTS OP ENERGY TBCHNOLOGIFS (Continuedi

\begin{tabular}{|c|c|c|c|c|c|c|}
\hline \multirow[b]{2}{*}{ Social Impacts by Category of Impacts } & \multicolumn{5}{|c|}{ Social Level of Impact } & \multirow{2}{*}{$\begin{array}{l}\text { Solar Energy Technology } \\
\text { Associated with Impact }\end{array}$} \\
\hline & Ind. & Group & Org. & Community & Society & \\
\hline $\begin{array}{l}\text { - What policy-related issues concerning } \\
\text { utilities will arise with widespread } \\
\text { use of solar energy? } \\
\text { - Increased governmertt regulations on } \\
\text { energy generally (OToole, 1976; } \\
\text { Hayes, 1977). } \\
\text { - Change in utility response to } \\
\text { energy demands and opportunities. } \\
\text { - New roles for utilities, back- } \\
\text { up and buy-back (Solar Energy in } \\
\text { Review, 1979). } \\
\text { - Will efficient use of energy at the } \\
\text { community level influence the alloca- } \\
\text { tion of energy to the community by } \\
\text { utilities? } \\
\text { With exponential growth of alterna- } \\
\text { tive energy systems and temporary } \\
\text { power. outages of those systems, how } \\
\text { will utility peak back-up loading be } \\
\text { aff ected? } \\
\text { Will the regulated ability of } \\
\text { electric monopoli es to set rates } \\
\text { encouraging high usage of electricity } \\
\text { present barriers to widespread utiliza- } \\
\text { tion of alternative tezhnologies? } \\
\text { Ineff eciencies in the processes } \\
\text { of energy production, distribution, } \\
\text { and service. } \\
\text { - What is the relationship between } \\
\text { community producer/consumer and } \\
\text { electric/gas utilities on buy-back } \\
\text { and back-up power rates? }\end{array}$ & & & $\begin{array}{l}x \\
x\end{array}$ & x & $\begin{array}{l}x \\
x\end{array}$ & $\begin{array}{l}\text { All } \\
\text { All } \\
\text { PV, SWECS, B }\end{array}$ \\
\hline
\end{tabular}


Table 4-1. SOCIAL IMPACTS OF ENRRGY TBCHNOLOGIES (Contirued)

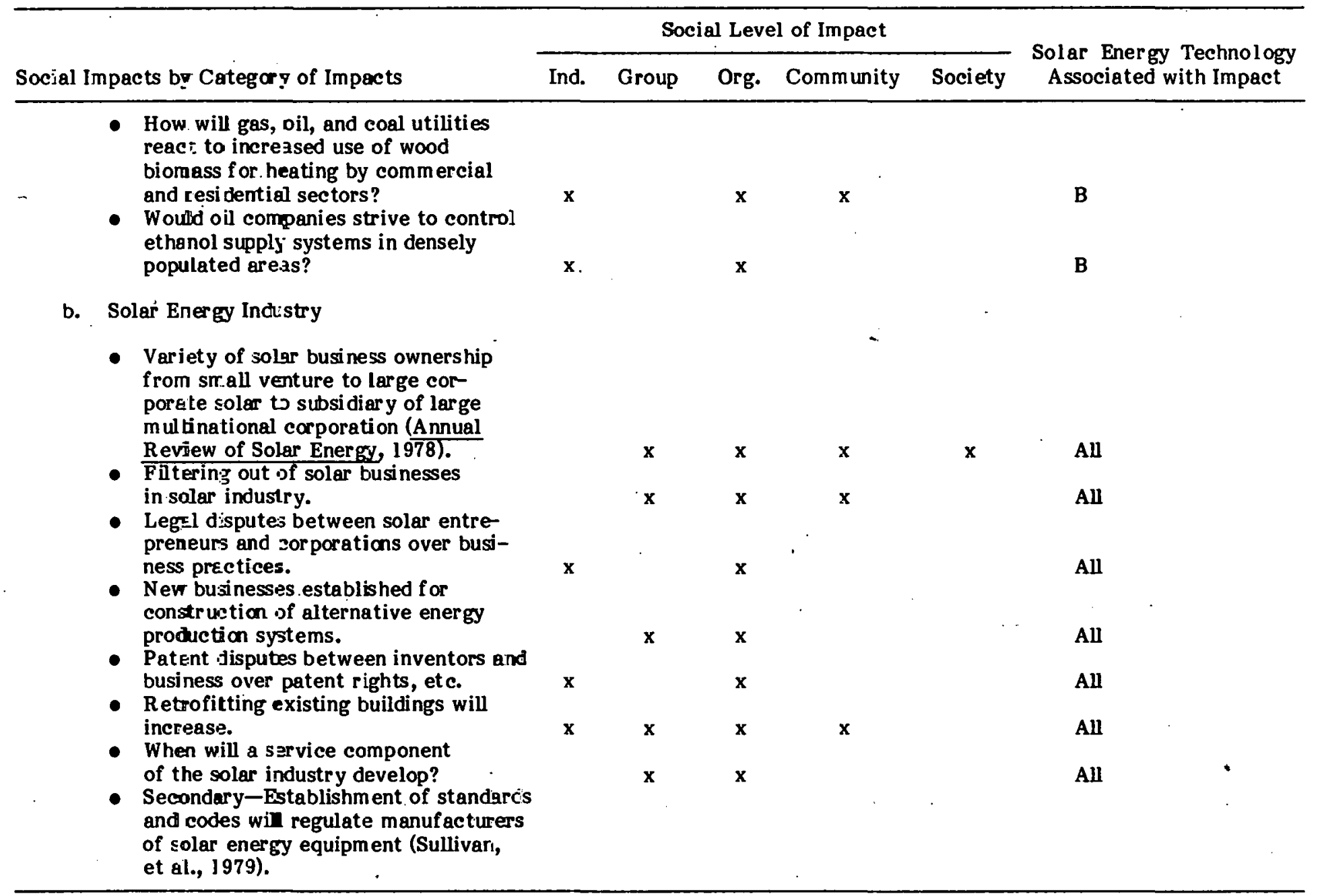


Table 4-1. SOCIAL IMPACTS OF BNERGY TBCHNOLOGIES (Continued)

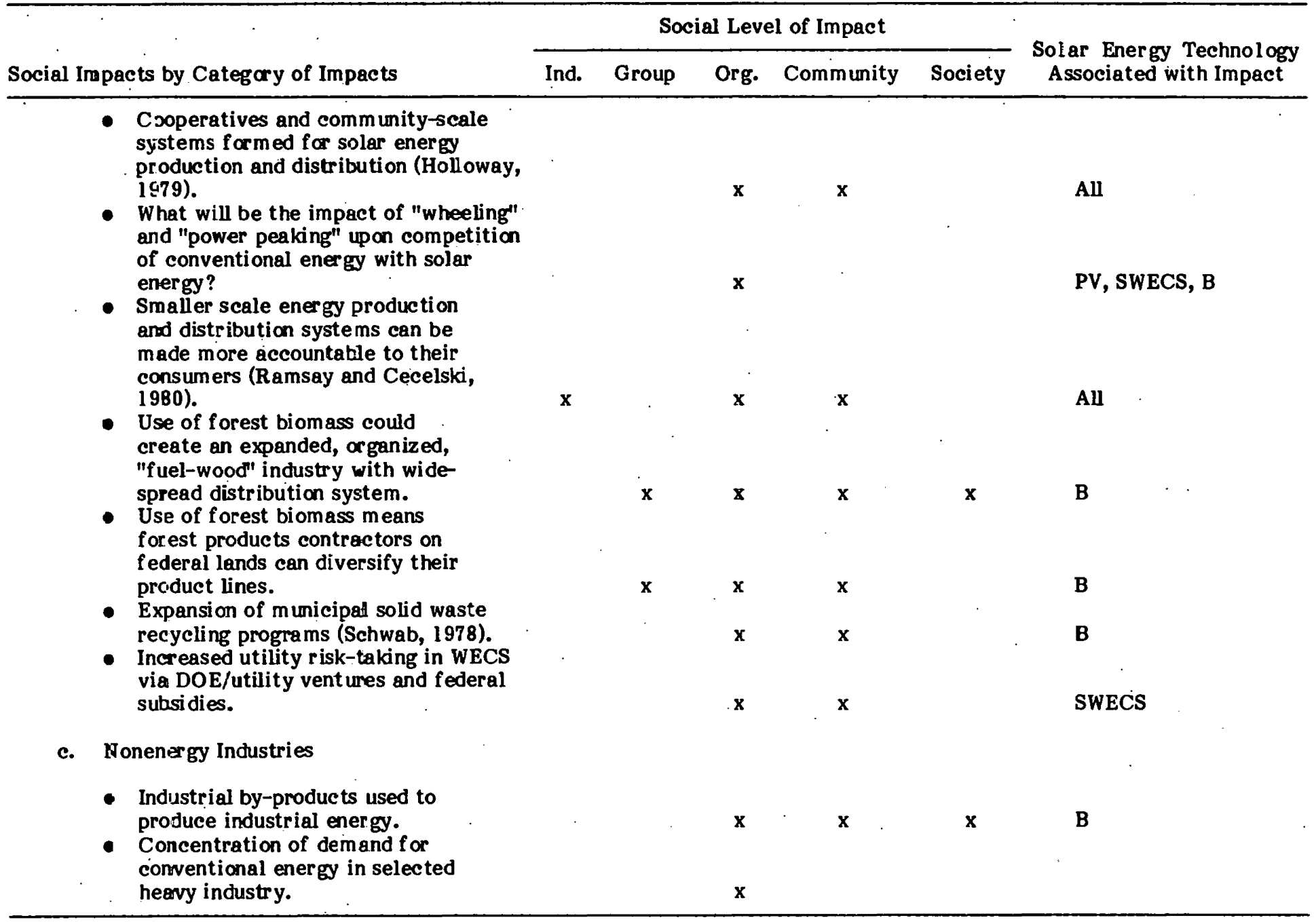


Table 4-1. SOCIAL IMPACTS OP BNERGY TECHNOLOGIES (Continue.d)

\begin{tabular}{|c|c|c|c|c|c|c|c|}
\hline & & & & al Lev & 1 of Impact & & \\
\hline Social I & apacts by Category of Impacts & Ind. & Group & Crg. & Comnunity & Society. & Associated with Impact \\
\hline & 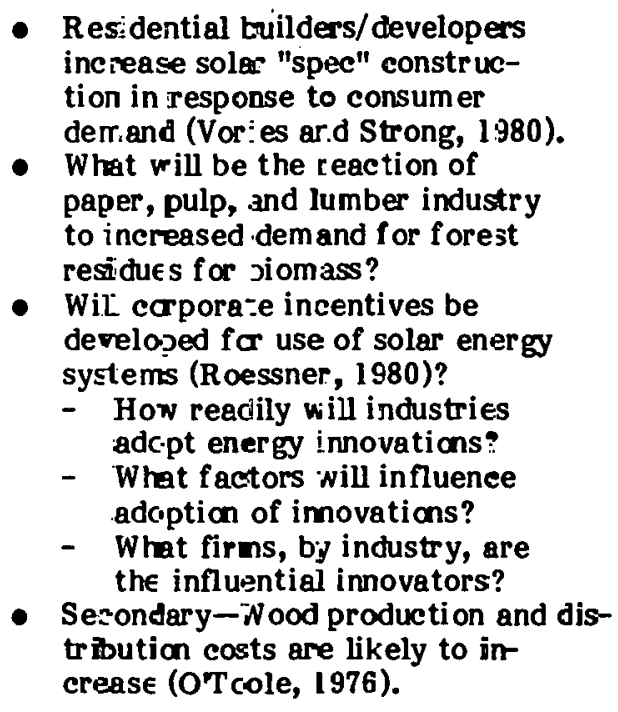 & $\mathbf{x}$ & & $\cdot$ & & $\mathbf{x}$ & $\begin{array}{l}\text { B } \\
\text { All }\end{array}$ \\
\hline d. & $\begin{array}{l}\text { Agricutural Industry } \\
\text { Will there be development of new } \\
\text { specialized agribusiness in fuel } \\
\text { produetion? } \\
\text { Wruld farm cooperatives gain in } \\
\text { membershif by et hanol production? } \\
\text { Wruld farm cooperatives become a } \\
\text { mejor marketing, vehicle for agri- } \\
\text { cultural ethanol production? } \\
\text { Will egriculiure Jevelop more } \\
\text { efficient practices of food and } \\
\text { fi'er ?roduetion as a consequence oi } \\
\text { on-farm fuel production (OToole, } \\
\text { 1976)? }\end{array}$ & $x$ & $\mathbf{x}$ & $\begin{array}{l}\mathbf{x} \\
\mathbf{x}\end{array}$ & & & $\begin{array}{l}\text { B } \\
\text { B } \\
\text { B }\end{array}$ \\
\hline
\end{tabular}


Table 4-1. SOCIAL IMPACTS OP ENRRGY TBCHNOLOGIES (Continued)

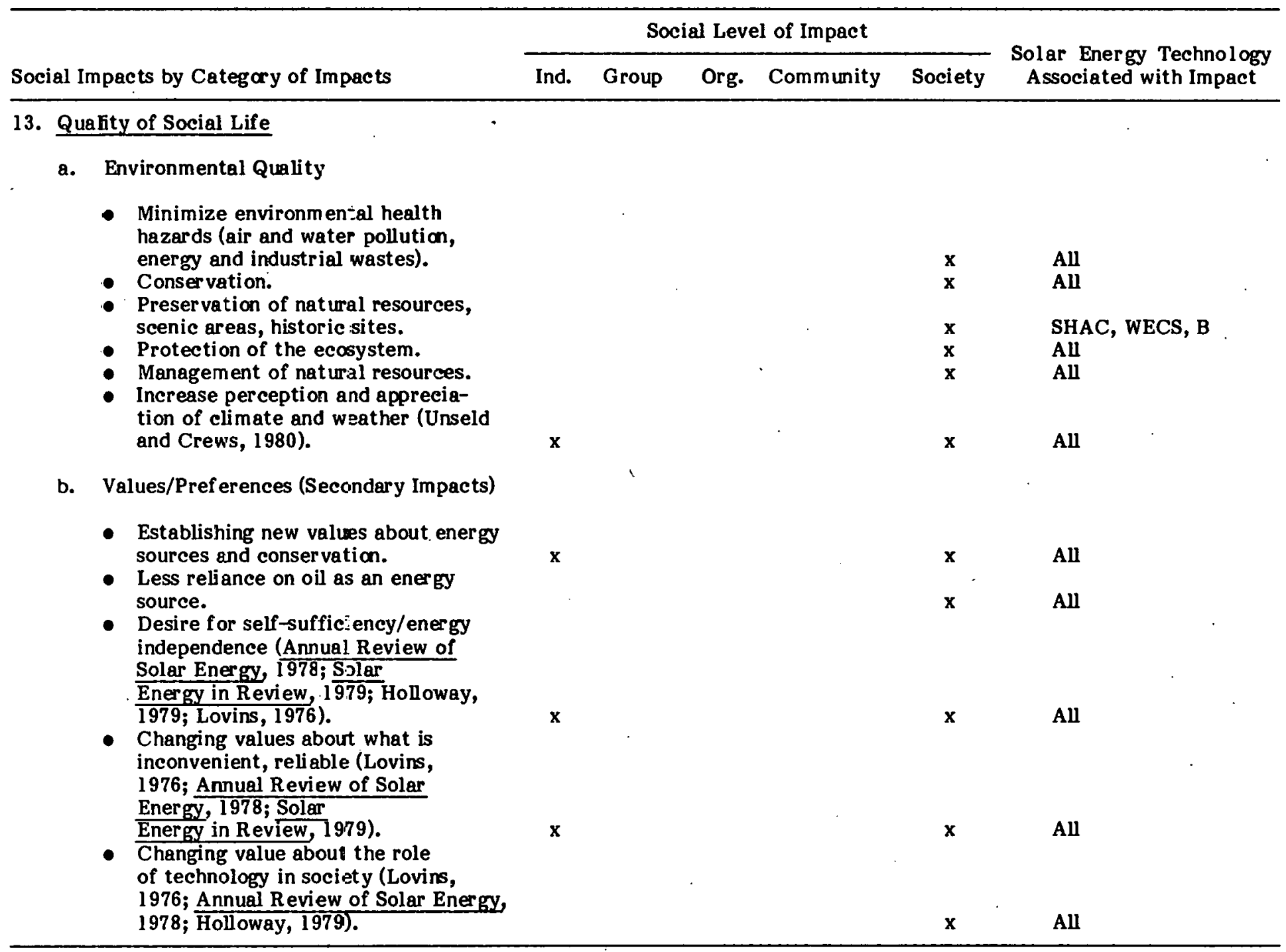


Table 4-1. SOCIAL IMPACTS OF ENERGY TBCHNOLOGIES (Continued)

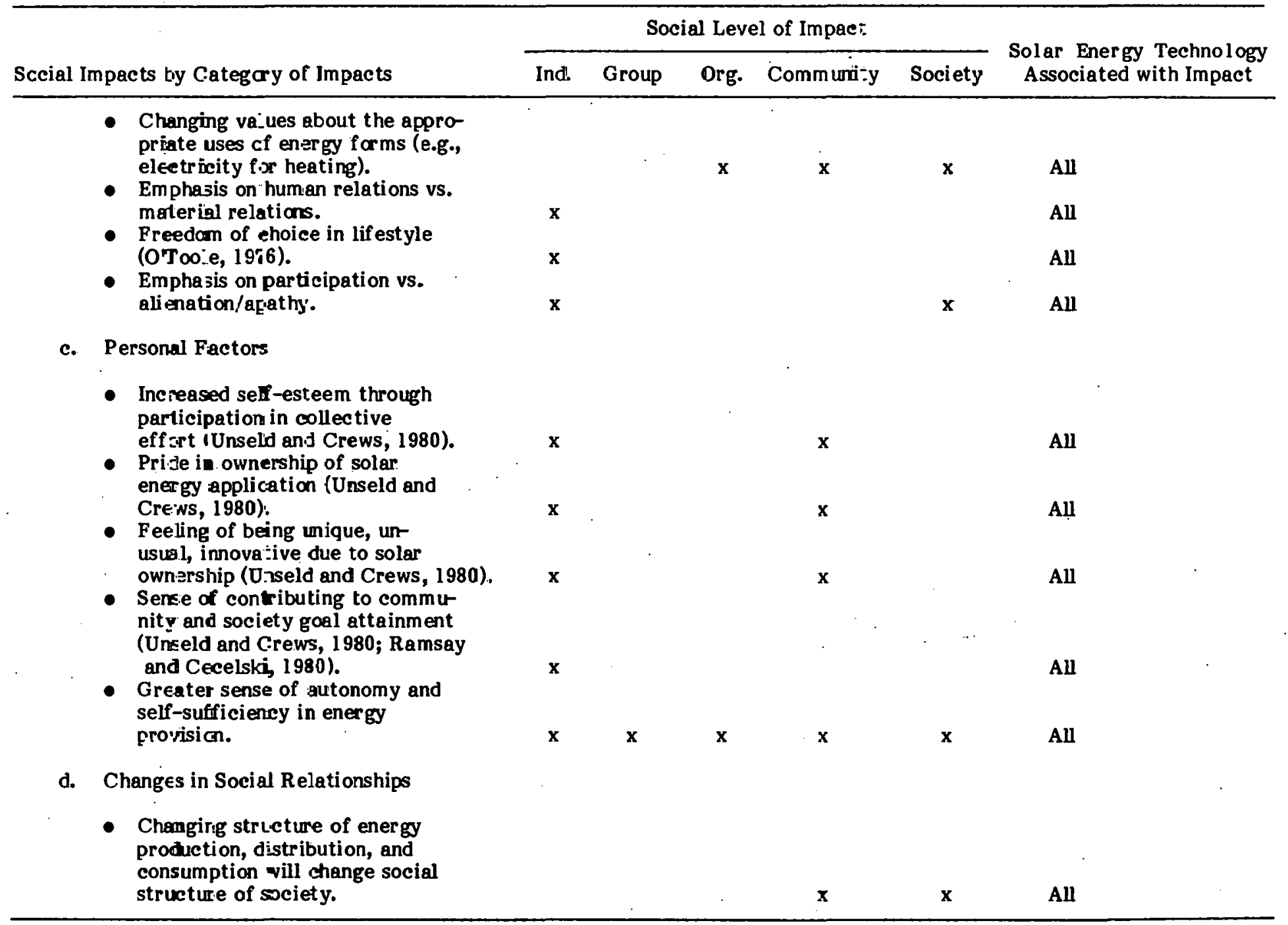


Table 4-1. SOCLAL IMPACTS OP BNERGY TBCHNOLOGIFS (Continued)

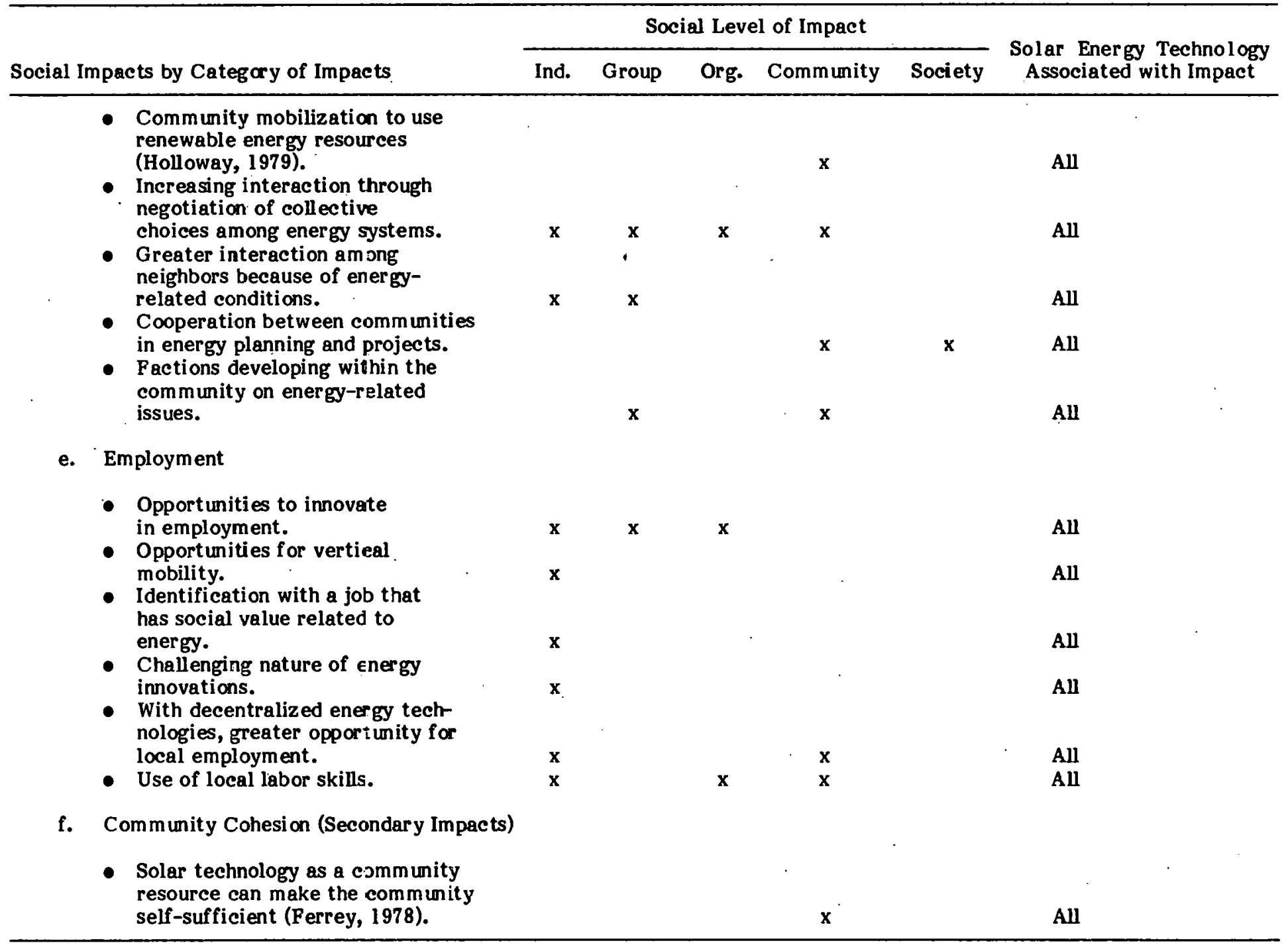


Table 4-1. SOCIAL IMPACTS OP ENERGY TECHNOLOGIES (Continued)

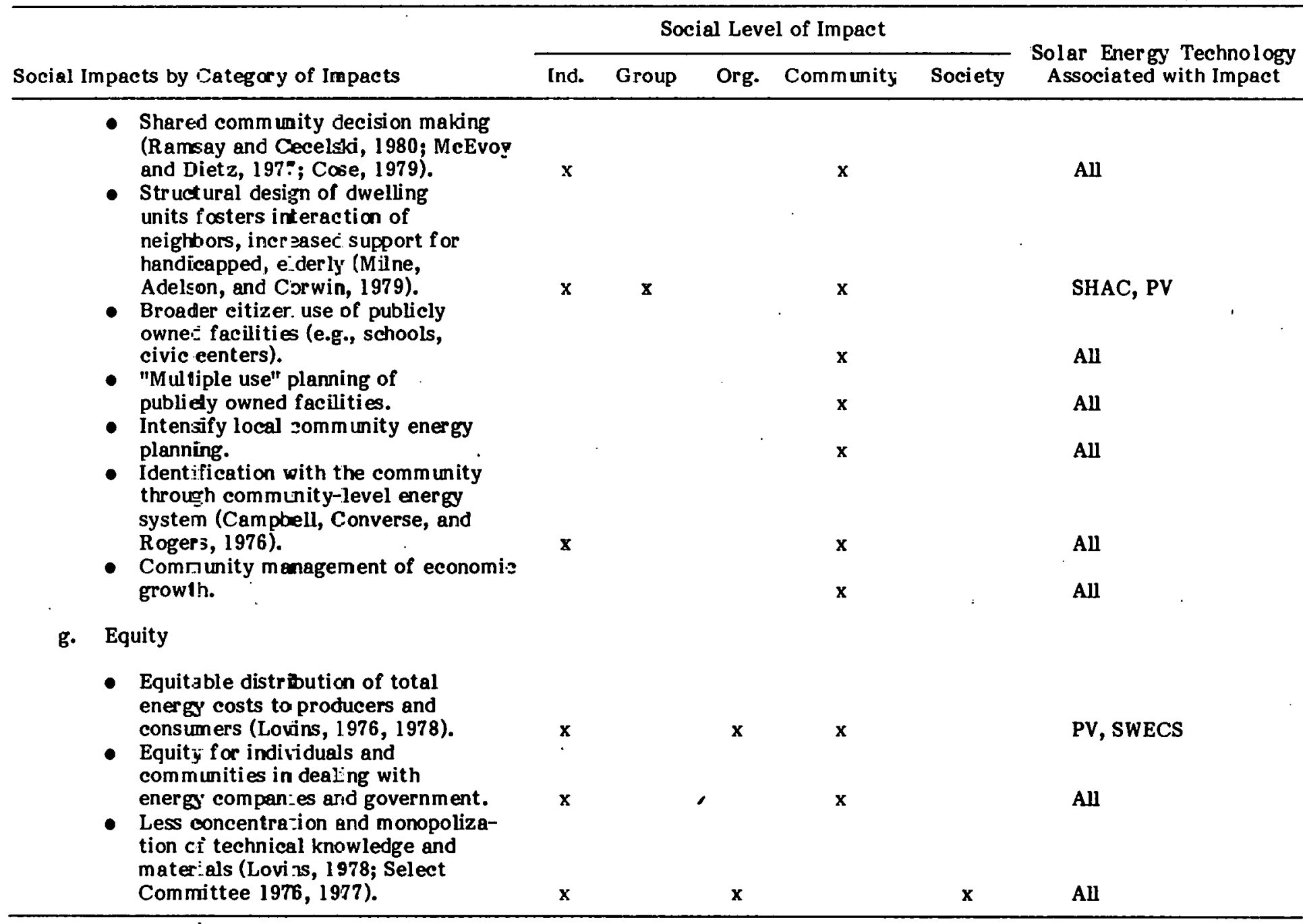


Table 4-1. SOCIAL IMPACTS OF RNERGY TECHNOLOGIES (Concluded)

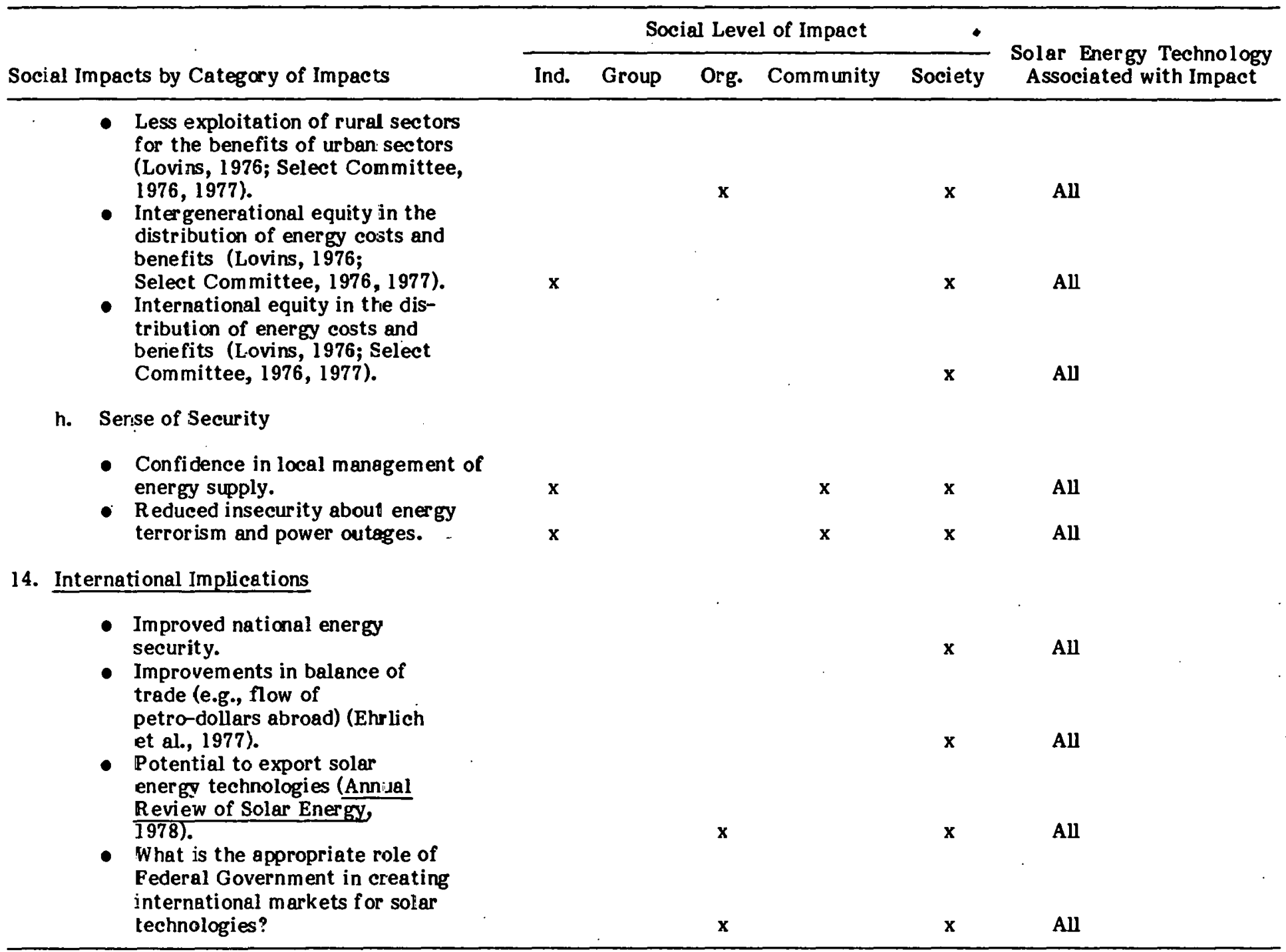




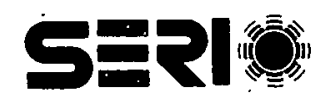




\section{SECTION 5.0}

\section{SOCIAL IMPACTS OF PROPOSED POLCY INITIATIVES}

This section presents nine proposed national-level public policy initiatives designed to accelerate solar energy use and the likely salient social impacts of each initiative. These initiatives are designed to expand the current level of federal eff ort with a selection of programs aimed at accomplishing specific cost-eff ective objectives. The proposed policy initiatives are to promote the use of solar energy in four sectors: residential/commercial buildings, industry, utilities, and government. After briefly describing three optimal levels of government support and each proposed initiative, the likely social impacts of implementing each initative are presented.

\subsection{PROPOSED LEVELS OF GOVERNMENT SUPPORT}

A wide range of government programs could increase solar energy use. The programs vary both in the nature of the government activity and the amount of assistance they would provide. These programs can be grouped into three options representative of three levels of government support:

Option I: $\quad$ Continue existing federal programs but make them more effective.

Option II: Expand the current level of federal effort with the selection of programs aimed to accomplish specific cost-eff ective objectives.

Option III: Substantially increase federal support through a variety of programs to accelerate solar energy use as a high-priority national goal.

Option II, the "practical case," estimates that solar energy would supply about $15 \%$ to $20 \%$ of the projected U.S. energy demand by the turn of the century. This option represents the maximum contribution that solar technologies could reasonably be expected to make within the framework of traditional federal intervention. For each solar technology and potential application, estimates were made of what might be achieved over the base case (Option I) with a set of comprehensive and aggressive initiatives. The amount of solar penetration in the marketplace in the maximum practical case is less sensitive to energy prices than it is to the full range of government policies that would be adopted to achieve a national energy objective. The Option II level of eff ort was selected for study because of its potential for implementation by the Federal Government in support of solar energy development and use.

The Option II level of government support for accelerating use of solar energy suggests a set of national-level policy initiatives designed to accomplish specific cost-effective objectives. The criteria for selecting an initiative for study were that it must have been introduced as a bill in the 96 th Congress, $*$ represent an expansion of an existing federal program, and accomplish cost-effective objectives. The set of selected initiatives had to reflect a pace of enactment and level of federal effort consistent with the achievement of the $15 \%$ to $20 \%$ solar goal by the turn of the century. Also, as a set, the initiatives

*Of the nine initiatives introduced as bills in the 96 th Congress, only the Solar Energy and Conservation Bank initiative was enacted. 
had to encourage solar energy use in four end-use sectors: residential/commercial buildings, industry, utilities, and government.

Five policy initiatives are proposed for the residential/commercial sector, one initiative each for the industry and utility sectors, and two for the government sector. Since these initiatives are offered by end-use sector, the identification of likely social impacts of each policy initiative will be presented by sector. However, each policy initiative will be investigated and presented independently. Although it was anticipated that interactions among policy initiatives and social impacts would occur, those interactions were not investigated. It is important to remember that the impacts and questions are cursory, cannot be rank-ordered, and do not suggest either the extent or the intensity of impact.

\subsection{RESIDENTIAL/COMMERCIAL BUILDINGS SECTOR INITIATIVES}

Five policy initiatives were proposed to enhance solar energy use in the residential/ commercial buildings sector. Each of them will be described in terms of the federal programs it was designed to affect.

\subsubsection{Passive Solar Tax Credit}

This initiative proposed a tax credit for builders of energy-efficient, passive solar houses and commercial structures. The new structures would help provide working demonstrations of most building types in all parts of the nation. These buildings would also provide a solid base of experience and data and increase builders' and the public's acceptance of the technologies. These would be necessary to establish eff ective standards for highly energy-efficient buildings during the next 10 years. The credit would be to builders rather than to owners and would be effective for 5 years after enactment. Table 5-1 presents likely social impacts of this initiative. 
Table 5-1. SOCIAL IMPACTS OF THE POLICY INITATIVE TO PROVIDE A TAX CREDIT POR ENERGY-EFFICIENT CONSTRUCTION*

\begin{tabular}{cccccc}
\hline & Level of Social Impact & $\cdot$ & Technology \\
\hline Indivicual & Group & Organization & Community & Society & With Impacts \\
\hline
\end{tabular}

Greater incentive to builders/developers of residential buildings

to design and build with passive solar.

SHAC, PV

Some builders may pass on costs of energy-

efficient construction to buyers and

not pass on tax credit benefits.

SHAC

Secondary Impact: Will

encourage financial

institutions to finance

energy-efficient con-

struction and some

solar energy technologies.

SHAC

Secondary Imfact: Could stimulate community and interest

groups to pressure financial institutions to off er financing

of solar applications.

SHAC

Secondary Impact: Lenders

become aware of incentives

for the construction of

solar energy systems.

SHAC

Secondary Impact: What impact on consumer choice for energy does the timing of the delivery of an incentive have (Ashworth, 1979)?

SHAC

Secondary Impact: Increase marketability of homes because of

lower overall life-cycle cost of passive solar.

SHAC

*Impacts afferting more than one level of society are written across the columns of the levels they are likely to affect. Primary and secondary social impacts are specified, and gaps in existing knowledge of likely social impacts are presented as questions. 
Table 5-1. SOCIAL IMPACTS OF THE POLCY MITIATIVE TO PROVIDE A TAX CREDFT FOR ENERGY-EFFICIENT CONSTRUCTION (Contimued)

\begin{tabular}{cccccc}
\hline & Level of Sccial Impact & & & Technology \\
Individual & Grolip & Ozganization & Community & Society & Associated \\
\hline
\end{tabular}

Will favor builders with prior passive solar building

experience, and disadwantage builders of conventional homes. - SHAC

Secondjry lmpact: Encourage small business development. . . SHAC

Secondary Impact: Mass medie coverage and advertising of passive designs for homes.

SHAC

Secondary Impact: Demand for passive solar comporents for residential buildings will increase. SHAC

Secondary Impact: Greater demand for

consumer protection.

SHAC

Secondary Impact: Need for warranties on

passive solar components.

SHAC

Secondary Impact: Stimulate expansion of business and solvency

of pass.ve solar designers and builders.

SHAC

Secondary Impact: Estabæish standards and codes

to ensure energy' efficiency of passive solar homes.

SHAC

Secondary mpaet: Change conventional building practices. SHAC

Secondary Impact: Increase de.nand for energy-efficient construction materials and equipment. SHAC

Secondary Impact: Increase need for tuilding performance

standards for passive solar homes. 
Table 5-1. SOCIAL IMPACTS OP THE POLCY INITIATIVE TO PROVIDE A TAX CREDIT POR ENERGY-EFFICIENT CONSTRUCTION (Concluded)

\begin{tabular}{lllll}
\hline & & Level of Social Impact & & $\begin{array}{c}\text { Technology } \\
\text { Associated } \\
\text { With Impacts }\end{array}$ \\
\hline & Group & Organization & Community & Society \\
\hline & $\begin{array}{l}\text { Secondary Impact: } \\
\text { solar in residential buildings will push to extend the } \\
\text { time per iod for tax credits for energy-efficient con- } \\
\text { struction. }\end{array}$ & SHAC \\
\hline
\end{tabular}




\subsubsection{Solar Development Bank}

This initiative entailed establishing a Solar Bank (see Table 5-2) to ensure that financing would be available on reasonable credit terms to users of solar energy. The Bank would be a federally supported corporation able to buy mortgages and home improvement loans from banking, savings and loan, and insurance institutions. Primarily through secondary market operations, the Bank would commit itself to the purchase of mortgages and home improvement loans for buyers of solar systems. These secondary market operations would include the traditional functions of the GNMA, the Federal National Mortgage Association, and the Federal Home Loan Mortgage Corporation as they apply to financing solar energy systems but would be significantly expanded (DOE, 1979, pp. 24-25). 
Table 5-2. SOCIAL IMPACTS OP THE POLICY INITIATIVB TO ESTABLISH A SOLAR DEVELOPMENT BANK TO PROVIDE SUBSIDIZRD AND UNSUBSIDIZED RESIDENTIAL LOANS AND GUARANTEES *

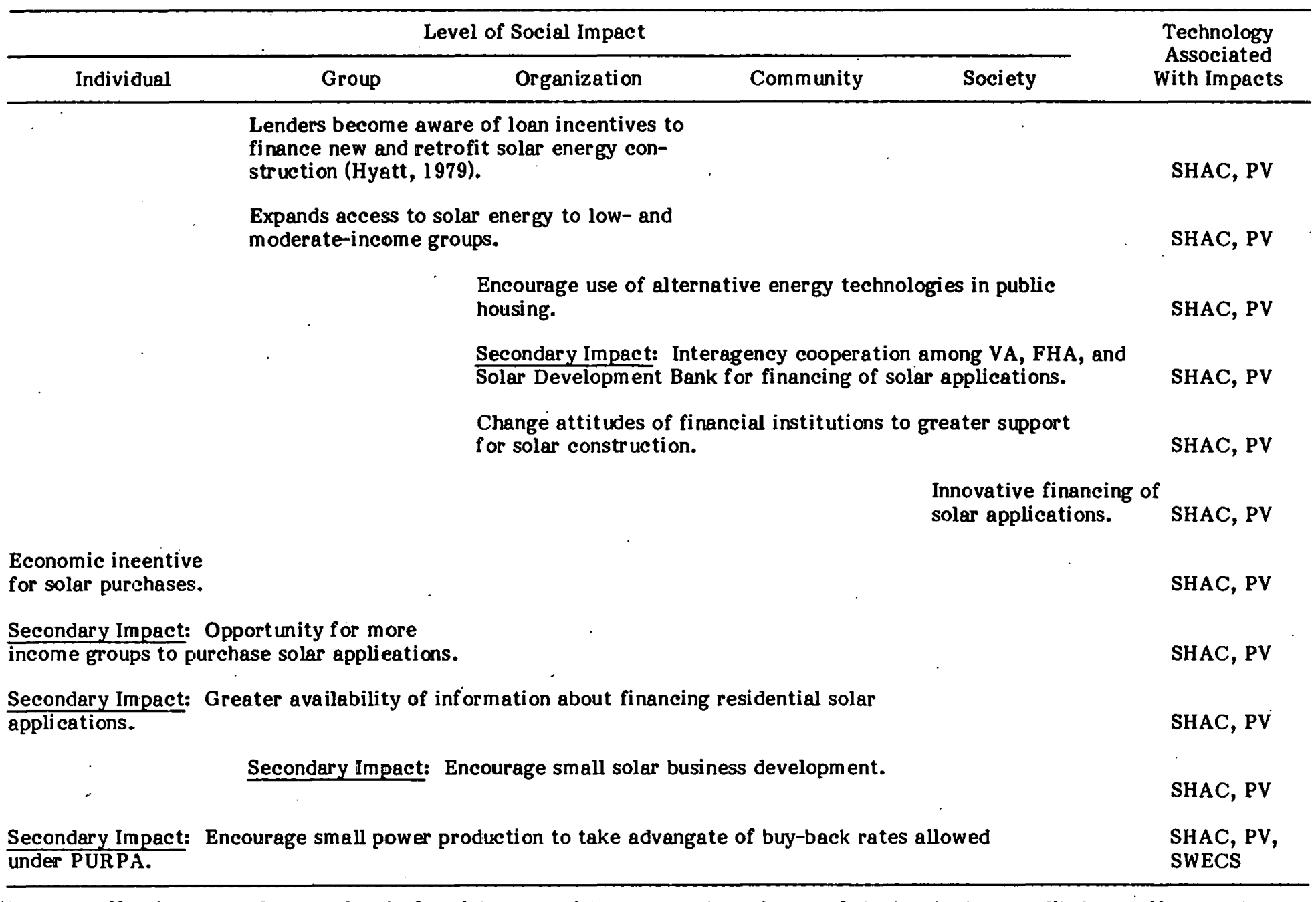

*Impacts affecting more than one level of society are written across the columns of the levels they are likely to affect. Primary and secondary social impacts are specified, and gaps in existing knowledge of likely social impacts are presented as questions. 
Table 5-2. SOCIAL MPACTS OF THE POLICY INITATIVE TO ESTABLISH A SOLAR DEVELOPMENT BANK TO PROVIDE SUBSIDIZRD ANE: UNSUBSIDIZED RESIDENTIAL. LOANS AND GUARAYTEES (Concluded)

\begin{tabular}{cccccc} 
& & Level cf Sorial Impect & & Technology \\
\hline Individual & Group & Organization & Community & Society & Associated \\
\hline
\end{tabular}

To what extent will a su:cessful Solar Development Benk inflıence federal policies about utility financing

of residential solar energy sys:ems?

SHAC, PV

Secondary Impact: Community pressure on Federal Government for subsidzed community loans end guarentees.

SHAC, PV

Seconjary Impact: Potential for consolidation of Solar Development 3ank and National Consumer Cooperative Bank.

Solar lobbies will pressure the Federal Government to increase subsidized and unsubsidized residential

loans and guarantees.

SHAC, PV

Seconidary Impact: Stimulate further innovative financing for sclar eriergy applications.

SHAC, PV

Increase number of $\varepsilon$ oplications and loans for residential use

of solar energy systems.

SHAC, PV 


\subsubsection{Public Housing Assistance Programs}

This initiative proposed two 4-year, $\$ 10$ million programs to enhance solar energy use among the poor and to set goals for solar use in HUD housing assistance programs. This initiative calls for two programs: a low-income grant program and a prototype public housing program. The low-income grant program provided $80 \%$ grants to eligible homeowners, owners of condominiums, and members of housing cooperatives for the purchase and installation of solar energy systems. HUD would administer this program and distribute funds through the Community Development Block Grant Program in urban areas and through the delegation of funds to the Farmers Home Administration in rural areas. Eligibility would be restricted to those within the $80 \%$ of area median income guidelines for the Low Income Rental Assistance Program. Also, CETA programs would be used to train low-income workers in the manufacture and installation of solar energy systems (DOE, 1979, pp. 18-20).

The prototype public housing program proposed asking HUD to set goals for solar energy use in federal housing programs, to increase public housing prototype costs up to $20 \%$ where solar energy systems are used, to extend FHA mortgage insurance limits for solar energy, and to increase appropriations for Public Housing and Section 8 programs by $\$ 10$ million a year to fund solar energy systems. The likely social impacts of each program of this initiative are presented in Table 5-3. 
Table 5-3. SOCIAL IMPACTS OP THB POLICY INITIATIVE TO ENHANCE SOLAR OSE BY THE POOR THROUGH TWO INTERRELATED HUD HOUSING ASSISTANCE PROGRAMS*

\begin{tabular}{cccccc}
\hline & & Level of Social Impact & & Technology \\
& Group & Organzation & Community & Society & With Impacts \\
\hline Individual & Grogram 1 - Low-income grants for purchase ard installa-ion of solar energy systems: &
\end{tabular}

Program 1 - Low-income grants for purchase ar.d installa-ion of solar energy systems:

Substentiâl reduction in front-end cost. - SHAC

Reduce financing as a controlling factor in decision to adopt solar systems. SHAC

Make solar energy economically accessible for some fixed- and lowineome people.

SHAC

Some financial institutions will become involved

in financing selected solar projects for low-

income perple.

SHAC

Secondary Impact: May be need for HUD to provide technical assistance

to low-income groups to arrange $20 \%$ financing.

SHAC

Secondary Impact: Encsurage urban area housing

cooperatives among low-income groups.

SHAC

Secondary Impact: Provide training opport unities for low-income workers for installation and maintenance of solar energy systems.

SHAC

Secondary Impact:

More jobs for urban

minority laborers in

solar energy industry

(Cose, 1979).

SHAC

More jobs $f$ or the less

sk:lled (Lovins, 1976;

MeEvcy and Dietz, 1977;

Ostendorf, 1980).

SHAC

*Impacts aff ecting more than one level of societ $y$ are written across the columns of the levels they are likely to affect. Primary and secondary socikl impacts are specified, and gaps in existing knowledge of likely social impaets are presented as questions. 
Table 5-3. SOCIAL IMPACTS OP THE POLICY NNITIATIVE TO ENHANCE SOLAR USE BY THE POOR THROUGH TWO INTERR BLATED HUD HOUSING ASSISTANCE PROGRAMS (Continued)

\begin{tabular}{|c|c|c|c|c|c|}
\hline \multicolumn{5}{|c|}{ Level of Social Impact } & \multirow{2}{*}{$\begin{array}{c}\text { Technology } \\
\text { Associated } \\
\text { With Impacts }\end{array}$} \\
\hline Individual & Group & Organization & Community & Society & \\
\hline
\end{tabular}

Secondary Impact: Increase community-level labor disputes among unions and nonunion workers over solar installations (Livingston, 1979).

Secondary Impact: New minority business
established in urban areas for manuf acture and installation of solar energy systems.

Retrofitting of existing residential

buildings will increase.

Secondary Inpact: Potential for negative financial impact on utilities providing back-up power to housing cooperatives using solar energy.

SHAC

Secondary Impact: Individual- and comm unity-established solar access agreem ents (Pollock, 1979).

SHAC

Change in building codes to permit installation of solar energy syștems.

Increased public

participation in energy

decision making (Cook,

1979; Ramsa' and Cecelski,

1980).

SHAC

Secondary Inpact: Increased lobbying on Federal Government to extend assistance for solar use in housing for low- and moderate-income groups.

Greater social acceptability of solar energy by neighbors based on experience with solar energy sysiems. 
Secondary Inpact: Creation of local-level

zoning reguiations and building codes to permit use of solar energy in public housing. 
Table 5-3. SOCIAL IMPACTS OF THE POLCY INITATTVE TO ENHANCE SOLAR USE BY THB POOR THROUGH TWO INTERR BLATED GUD HOUSING ASSISTANCE PROGRAMS (Continued)

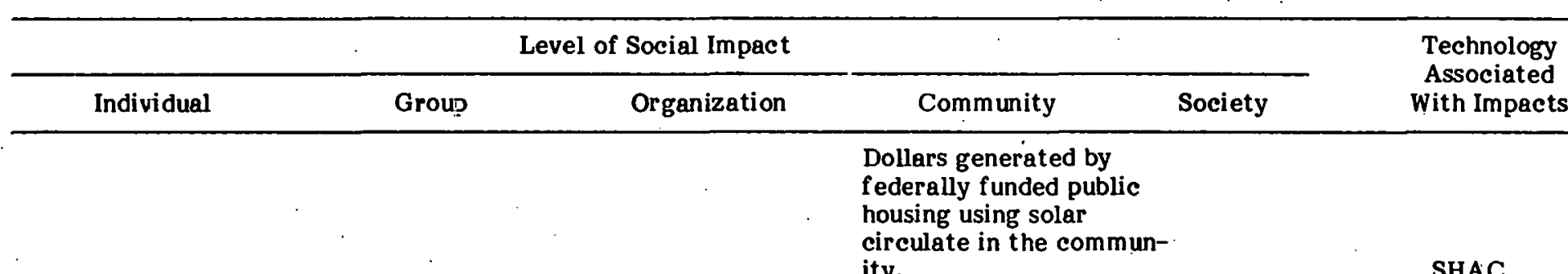

ity.

Secondary Impact:

Perceived monetary

savings on utility bills.

SHAC

Secondary Impact: Potential for unattractive residential building designs and

installations (Franta, 1979; Solar Energy in Review, 1979; RERC, 1980).

SHAC

Secondary Impact:

Problems with maintenance

of solar energy systems.

SHAC

Secondary Impact: Will solar energy create new and viable design and construction options for public housing?

SHAC

Secondary Impact:

Potential for develop-

ment of community scale

energy systems to provide

space and water heating and

electricity for public housing.

SHAC

Secondary Impact:

Less reliance on oil

and coal as energy

SWECS, B

source.

SHAC,

SWECS, B 
Table 5-3. SOCIAL IMPACTS OP THE POLICY DNTIATIVE TO ENHANCE SOLAR USE BY THE POOR THROUGH TWO INTERR ELATED HUD HDUSING ASSISTANCE PROGRAMS (Concluded)

\begin{tabular}{|c|c|c|c|c|c|}
\hline \multicolumn{5}{|c|}{ Level of Social Impact } & \multirow{2}{*}{$\begin{array}{l}\text { Technology } \\
\text { Associated } \\
\text { With Impacts }\end{array}$} \\
\hline \multirow[t]{4}{*}{ Individual } & Group & Organization & Community & Society & \\
\hline & & - & $\begin{array}{l}\text { Secondary Impas } \\
\text { Com nunity prid } \\
\text { ownership of sol } \\
\text { applications, uni } \\
\text { or innovative (U) } \\
\text { and Crews, } 1980\end{array}$ & & SHAC \\
\hline & & & $\begin{array}{l}\text { Community mob } \\
\text { to use renewabl } \\
\text { resolrces (Hollc } \\
1979 !\end{array}$ & & $\begin{array}{l}\text { SHAC, } \\
\text { SWECS, B }\end{array}$ \\
\hline & $\begin{array}{l}\text { Secondary Imp } \\
\text { labor in const } \\
\text { prototypes wi }\end{array}$ & $\begin{array}{l}\text { local and min } \\
\text { ublic housirig } \\
\text { gy systems. }\end{array}$ & & & SHAC \\
\hline
\end{tabular}




\subsubsection{Consumer Protection}

A fourth initiative that would enhance solar energy use in the residential/commercial sector involved consumer protection. The initiative had three parts: enhance existing voluntary testing and certification program (of solar energy equipment and components); require standardized solar product information; and develop warranty reinsurance program, if needed. The initiative called for an expansion of the existing voluntary product testing and laboratory certification program to develop quality and performance standards as well as testing procedures for a broader range of solar products. The results would provide consumers with standardized product information and make only products with standardized quality and performance information eligible for the residential solar tax credits. The initiative also recommended that the Federal Government consider offering a full-scale warranty reinsurance program to manufacturers of solar equipment if private insurance programs should be unsuccessful. The likely social impacts of each of the three parts of this initiative are provided in Table 5-4. 
Table: 5-4. SOCIAL IMPACTS OF THE POLCY INITIATIVE POR CONSUMER PROTECTION*

\begin{tabular}{cccccc}
\hline & Level cf Social Impact & & Technology \\
Individual & Group & Organization & Community & Society & With Impacts \\
\hline
\end{tabular}

I. Testing and certification program:

-Provides consumers with confidence in the quality of solar products.

-Establishes a frecedent for standardized certification of energy products.

Time requirements tic get solar equipment through certification

process could cause smag business to fail.

Eriminates inferiar,

ncincertified products

from competition.

Creates a standard within the industry for certified products.

$$
\begin{aligned}
& \text { Pressures solar product } \\
& \text { manuf acturers to conduct } \\
& \text { R\&D on their products }
\end{aligned}
$$

before marketing them.

Allows consum ers to dist.nguis 7 between solar products on the basis of whether or not tiney are certified.

Provides additional eanomic security for builders/developers using solar products.

Encourages builder/developers to provide service contracts

for solar equipment (E.ER C, 1930).

Secondary Impact: Will contribute to the cevelopment of a service component in the solar industry.

SHAC, PV

*Impacts affecting more than one level of societ g are writter across the columns of the levels they are likely to affect. Primary and secondary social impacts are specified, and gaps in existing knowledge of likely social impacts are fresented as questions. 
Table 5-4. SOCIAL IMPACTS OP THE POLICY INITIATIVB FOR CONSUMRR PROTBCTION (Continued)

\begin{tabular}{cccccc}
\hline & $\ddots$ & Level of Social Impact & & & $\begin{array}{c}\text { Technology } \\
\text { Associated }\end{array}$ \\
\hline Individual & Group & Organization & Community & Society & With Impacts \\
\hline
\end{tabular}

II. Standardized Product information

Provide consumers with more reliable information about solar products (Franta, 1979; Annual Review of Solar Energy, 1978).

Enable consumers to compare competing solar products.

Secondary Impact: Contributes to the development of a criterion for comparing across energy technologies.

Secondary Impact: Consumers knowledgeable about standardized solar product inf ormation become better sources of information for others.

What entity will have responsibility for

establishing a criterion by which to standardize

information about solar products?

How will utilities be involved in standardizing product information?

What solar product information will be standardized?

Will consumers play a role in establisting the criteria and standards for solar product information?

What role will the solar

industry play in stan-

dardizing solar product

information?

What impact will standardized inf ormation have on consumer acceptance of solar energy? 
Table 5-4. SOC

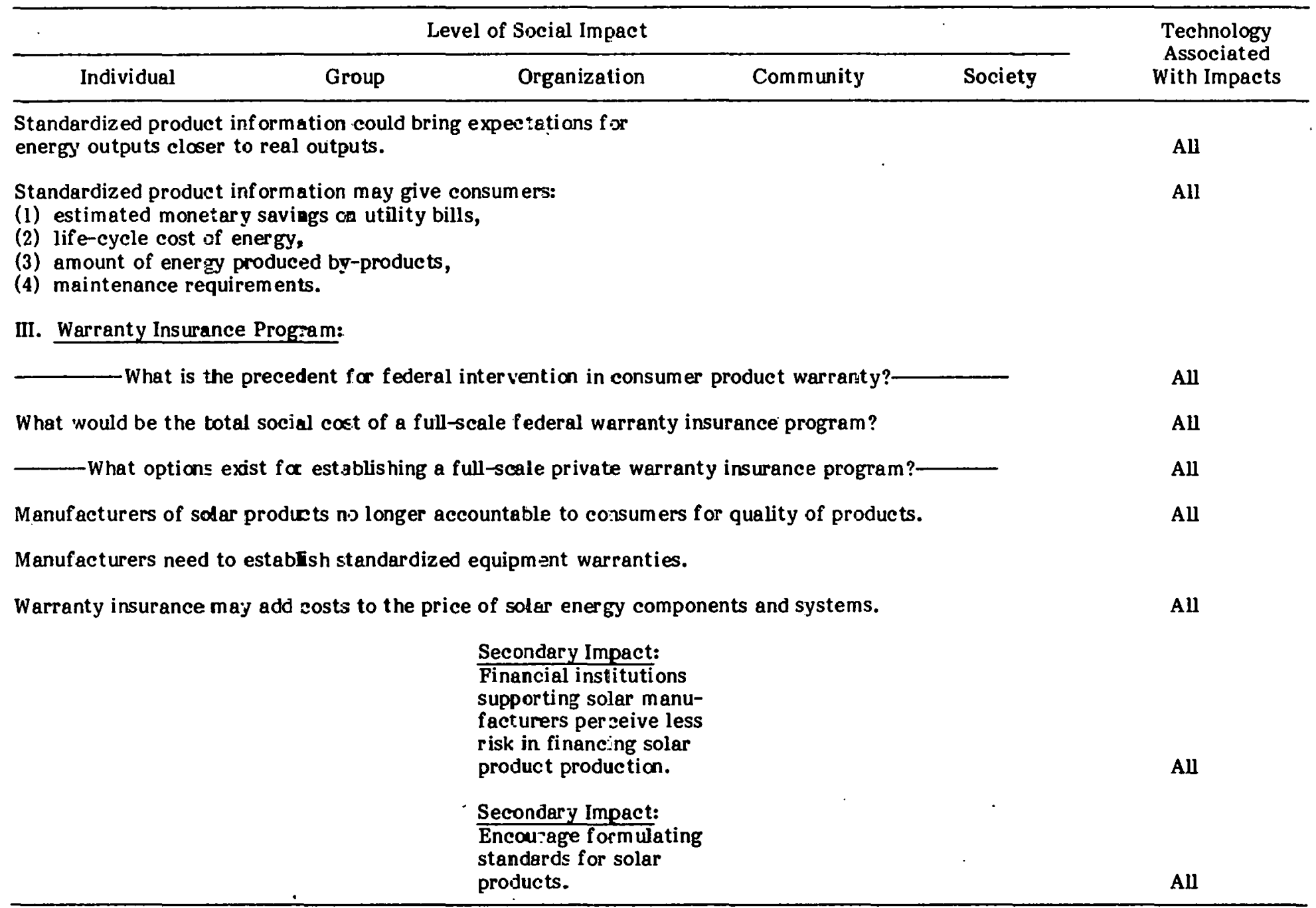


Table 5-4. SOCIAL IMPACTS OP THE POUCY INITIATIVE FOR CONSUMER PROTECTION (Concluded)

\begin{tabular}{|c|c|c|c|}
\hline \multicolumn{3}{|c|}{ Level of Social Impact } & \multirow{2}{*}{$\begin{array}{l}\text { Technology } \\
\text { Associated } \\
\text { With Impacts }\end{array}$} \\
\hline Individual & Organization & Society & \\
\hline \multicolumn{4}{|c|}{$\begin{array}{l}\text { Secondary Impact: Assurance to consamers } \\
\text { of solar products that faulty products } \\
\text { will be replaced at little or no cost } \\
\text { to the consurner. }\end{array}$} \\
\hline \multicolumn{3}{|c|}{$\begin{array}{l}\text { Secondary Impact: For consumers of solar products, reduces the risk associated with purchasing an } \\
\text { innovative eriergy product. }\end{array}$} & All \\
\hline \multicolumn{3}{|c|}{$\begin{array}{l}\text { Secondary Impact: Increase social acceptance of solar energy through reduced risk associated with the } \\
\text { purchase of rew products. }\end{array}$} & All \\
\hline
\end{tabular}




\subsubsection{Tax Credit for Leased Equipment}

The final policy initiative for increasing residential use of solar energy systems called for an extension of the investment tax credit to residential, leased solar equipment. This policy proposed to enable lessors of solar equipment to qualify for the regular investment tax credit for solar water heating and space heating and cooling investments. The regular investment tax credit would be amended to include leased solar equipment for residential property. This initiative would encourage both the leasing of solar equipment and the development of solar equipment leasing businesses. The proposed credits would expire 5 years after enactment. A significant distinction exists between renter-lessor and owner-lessor and is crucial to understanding the full impact of this initiative. Table 5-5 presents likely impacts of this initiative. 
Table 5-5. SOCIAL IMPACTS OF THB POLICY NNTIATIVB TO BXTEND INVESTMENT TAX CREDIT TO RESIDENTIAL LEASED SOLAR BQUIPMENT*

\begin{tabular}{cccccc}
\hline & & Level of Social Impact & & Technology \\
\hline Individual & Group & Organization & Community & Society & With Impacts \\
\hline
\end{tabular}

General Social Impacts:

Need utilities to tie together leased system with existing back-up system:

SHAC

Encourage solar equipment rental through existing and new rental outlets.

SHAC

Utilities involved in public information about hazards and safety factors in "do-it-

yourself" instellations.

SHAC

Potential for personal injury and property damage due to "do-it-yourself" installations. SHAC

Higher standards on solar equipment to be leased to protect consumers.

SHAC

Need for clear technical instructions f $\mathrm{f}$ installation of leased equipment.

SHAC

How would lezsing solar equipment avodd warranty and service problems?

SHAC

What rental ou:lets exist or need to be created

to off er leasing of solar energy equipment?

What incentive exists for rental outlets to

handle an unproven product in leased solar

property?

What response will dealers and distributors

have to leasing of solar equipment?

SHAC

Investment tax credit for leased solar equipment will have a different set of impacts on renter-lessors and owner-lessors.

SHAC, PV

*Impacts affecting more than one level of society are written across the columns of the levels they are likely to affect. Primary and secondary social impacts are specified, and gaps in existing knowledge of likely social impacts are presented as questions. 
Table 5-5. SOCIAL IMPACTS OF THE POLICY INITIATTVE TO EXTEND IIVESTMENT TAX CREDT TO RESIDENTIAL LBASED SOLAR BQUIPMENT (Coi:inued)

\begin{tabular}{cccccc} 
& & Level of Soeial Impact & & & Technology \\
Individual & Group & Organization & Comnunity & Society & With Impacts \\
\hline
\end{tabular}

Impacts on Owner-Lessors:

Leasirg arrangements could reduce front-end costs as a controlling factor in decision

making about solar.

Attractive option to developers/builders of commereial proparty to reduce overhead costs of energy.

SHAC

Will owners service their own systems or subcontract for maintenance and repair service?

SHAC

Commercial and residential lease agreements formed directly

between lessor and equipment. maruf acturers.

SHAC

Equipment certification and warranty insurance program

help marketing of leased solar equipment.

SHAC

Impacts on Renter-Lessors:

Complex legal issues and arrangerrents between renters and property owners on installation of leased solar equipment by rer:ters.

SHAC, PV

Potential for litigation between renter and property owner orer the installation and/or removal of leased sclar equipment by renter.

SHAC, PV

What factors would influence renters to lease solar equifment?

SHAC, PV

Tax c:edit to lease solar property will not be an incentiv 2 for lowand moderate-income renters.

SHAC, PV

Wha: lines of solar

energy applications

would te available for

lease:

SHAC, PV 
Table 5-5. SOCIAL IMPACTS OF THE POLICY INITIATIVE TO RXTBND INVESTMENT TAX CREDIT TO RESIDENTIAL LBASBD SOLAR BQUIPMBNT (Concluded)

\begin{tabular}{|c|c|c|c|c|c|}
\hline \multicolumn{5}{|c|}{ Level of Social Impact } & \multirow{2}{*}{$\begin{array}{l}\text { Technology } \\
\text { Associated } \\
\text { With Impacts }\end{array}$} \\
\hline Individual & Grouf & Organization & Community & Society & \\
\hline$\cdot$ & & $\begin{array}{l}\text { What solar energs } \\
\text { applications woul } \\
\text { provide renters } w \\
\text { incentives to leas } \\
\text { equipment? }\end{array}$ & & . & SHAC, PV \\
\hline \multicolumn{5}{|c|}{$\begin{array}{l}\text { Barriers to social acceptance of leasing solar equipment include uncertainties about: } \\
\text { system performance, getting enough isable energy, equipment malf unction and wear } \\
\text { out, visual appearances, siting installation, reliability of lease service. }\end{array}$} & SHAC, PV \\
\hline \multicolumn{5}{|c|}{ Uncertainty about monetary savings on utility costs over leasing costs. } & SHAC, PV \\
\hline
\end{tabular}




\subsection{INDUSTRIAL SECTOR INITIATIVES}

One policy initiative was offered for enhancing the use of solar energy in the industrial sector. The initiative proposed a 30\% investment tax credit or expensing for solar process heat systems used in industrial and agricultural applications. This proposal would provide an incremental 10\% investment tax credit over the level provided in the Energy Tax Act and would terminate 5 years after enactment. Alternatively, purchasers of solar industrial process heat systems could be permitted to deduct those expenditures for tax purposes in the year they were incurred. Biomass property would not be eligible for this incentive (DOE, 1979, p. 27). Table 5-6 presents the likely social impacts of this initiative. 
Table 5-6. SOCIAL IMPACTS OF THB POUCY INITIATIVB FOR 30\% TAX CREDIT OR EXPENSING FOR SOLAR PROCESS HEAT BQUIPMENT FOR INDUSTRY AND AGRICULTURE*

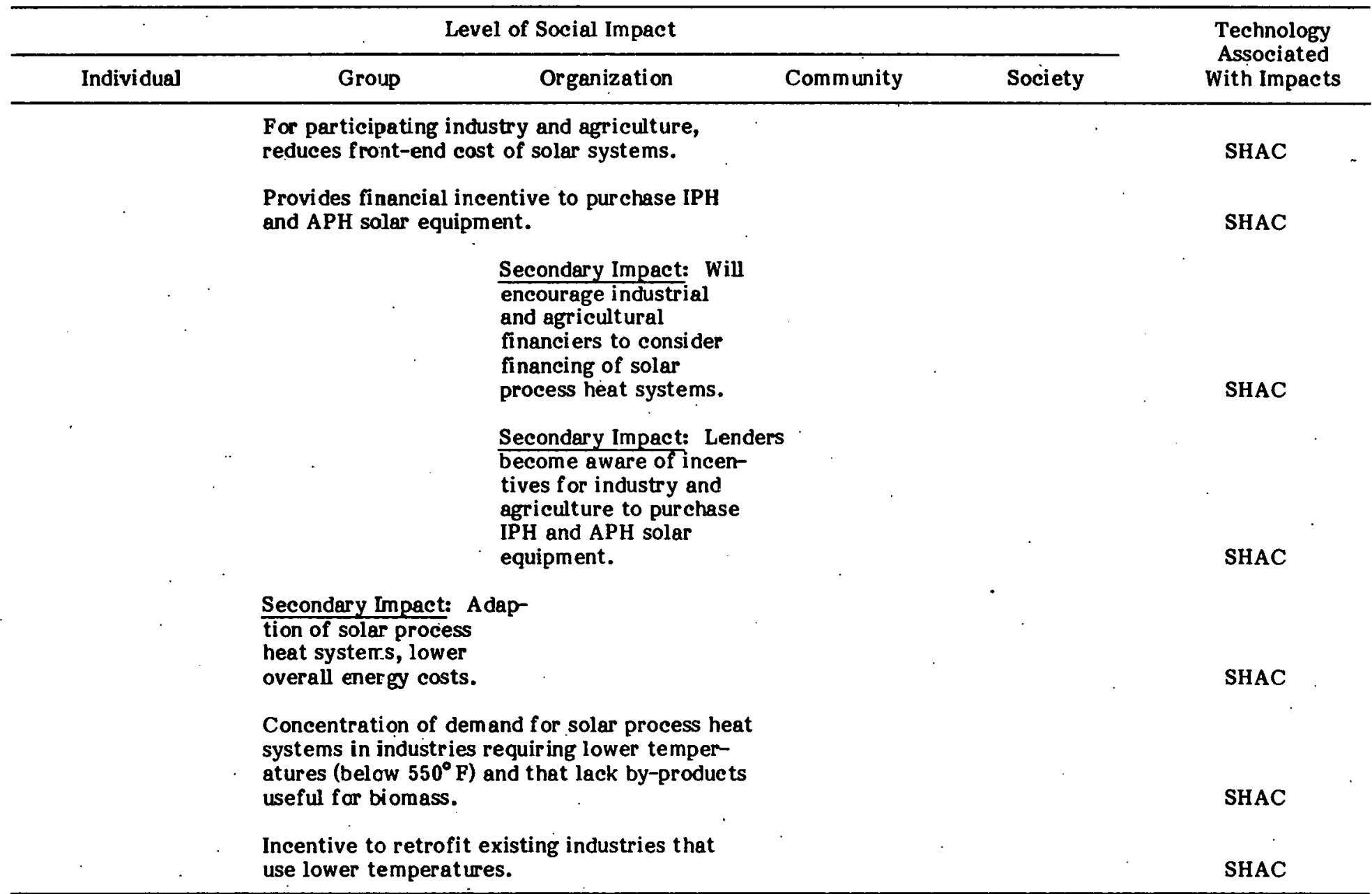

*Impacts affecting more than one level of society are written across the columns of the levels they are likely to affect. Primary and secondary social impacts are specified, and gaps in existing knowledge of likely social impacts are presented as questions. 
Table 5-6. SOCIAL IMPACTS OP THE POLICY INITIATIVE FOR 30\% TAX CREDIT OR EXPENSING POR SOLAR PROCESS HEAT BQUIPMENT POR INDUSTRY AND AGRICULTURE (Continued)

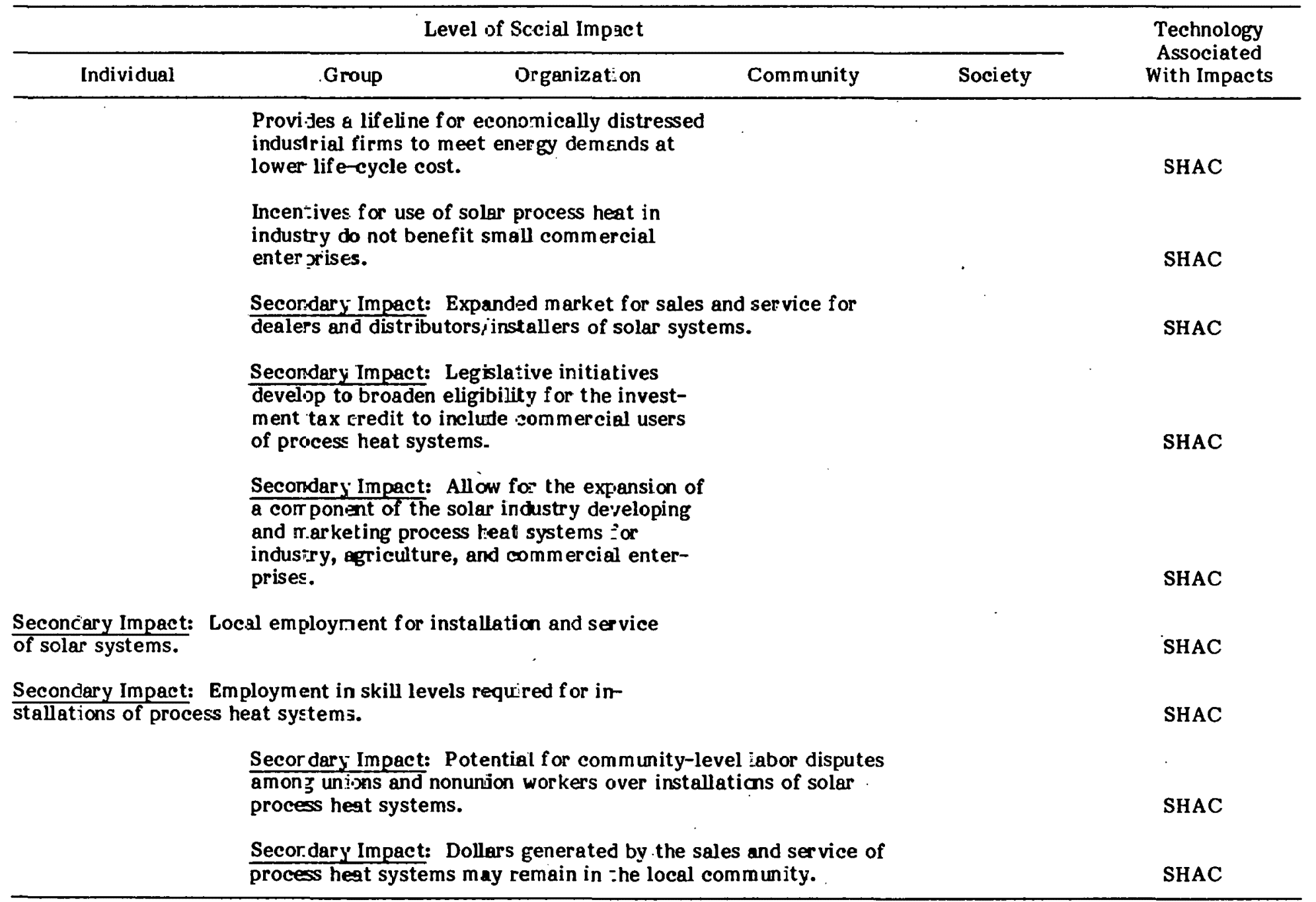


Table 5-6. SOCIAL IMPACTS OF THE POLICY INITIATIVE FOR 30\% TAX CREDIT OR EXPENSING POR SOLAR PROCESS HEAT BQUIPMENT FOR INDUSTRY AND AGRICULTURE (Concluded)

\begin{tabular}{ccccc} 
& Level of Social Impact & & \\
\hline Individual & Grouf & Organization & Community & Technology \\
Associated & Society & With Impacts \\
\hline
\end{tabular}

Barriers to social acceptability: uncertainty about getting enough needed energy; cost and reliability of backup systems.

SHAC

Secondary Impact: Factors enhancing social acceptability of IPH and

APH systems: Perceived monetary savings on utility bills; belief in

practicality of using solar as an energy source; reduced dependence

on oil.

SHAC

Secondary Impact: Quality of life impacts: Minimize environmental

pollution; desire for energy independence (Annual Review of Solar

Energy, 1978: Solar Energy in Review, 1979; Holloway, 1979;

Lovins, 1976); pride in ownership of solar energy (Unseld and Crews, 


\section{\$.4 UTILTY SECTOR INITIATTVES}

To promote the use of solar energy in the utility sector, a policy initiative with three components was proposed. First, it was recommended that the President encourage state regulatory commissions to consider conservation and solar energy applications in evaluating utility expansion plans. The second component recommended that the Rural Electrification Administration (REA) be required to increase loans directly to homeowners, farmers, and small businesses for the installation of solar energy systems. If necessary, legislation would be proposed to facilitate such administrative action and to enable the REA to lend directly to homeowners, farmers, and small businesses for solar energy or distributed systems whether or not those systems involved the use of electric power. The third component proposed that the Water and Power Resources Service and the U.S. Army Corps of Engineers be requested to develop plans to expand power generation at existing sites through utilization of wind and other solar energy systems. These plans would be used to consider expansion of the missions of each agency. Likely social impacts of each of these components are presented in Table 5-7. 
Table 5-7. SOCLAL IMPACTS OF THE POLCY INITATIVE APFECTING THE UTILTY SECTOR*

\begin{tabular}{cccccc} 
& & Level of Social Impact & & Technology \\
Incividual & Group & Organization & Community & Society & With Impacts \\
\hline
\end{tabular}

A. Presicential Letter to PUCs Requesting Consideration of Conservation and Solar Energy in Evaluating Expansion Plans:

PUCs could resent

Presidential intervention.

PUC response could

depend on political

affiliation.

B. Rural Electrification Support o: Solar Energy Projects:

Lower frant-end costs of solar to rural homeowners, farmers, and small businesses.

Depending on level of interest subsidy, REA loan program may extend solar option to lower income groups.

Secondar $\nabla$ Impact: Changes in routine

patterns of behavior associated with

energy.

Secondary Impact: Possible reduction in out-migration from farms because of lower costs of energy.

Secondary Impact:

Will use of solar

entail more main

tenance skills

and monitoring

behavior of owners

than conventional

energy technologies?

Secondary Impact: Will use of solar change farm building designs?

All

*Impacts affecting more than one level of society are written across the columns of the levels they are likely to affect. Primary and secondary social impacts are specified, and gaps in existing knowledge of likely social impacts are presented as questions. 
Table 5- $\pi$. SOCIAL IMPACTS OP THE POLICY INITIATIVE APFECTINT THE UTILITY SECTOR (Continued)

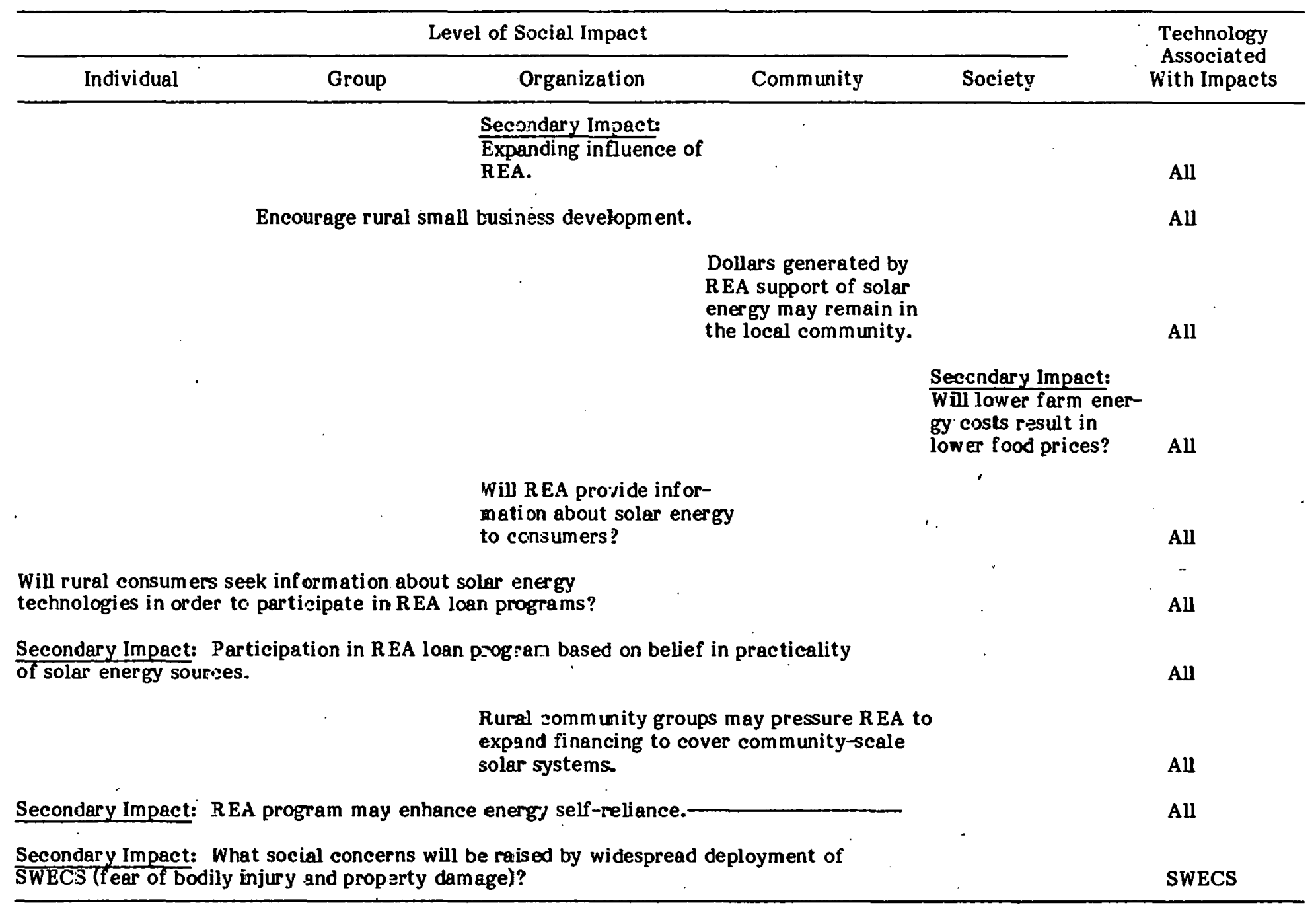

Will REA provide infor-

mation about solar energy

Rergy may remain in

Seccndary Impact

Will lower farm en

costs result in

ower food prices?

Associated

Expanding influence of

to consumers 
Table 5-7. SOCIAL IMPACTS OP THE POLCY INITIATIVB AFFBCTING THE UTHITY SBCTOR (Continued)

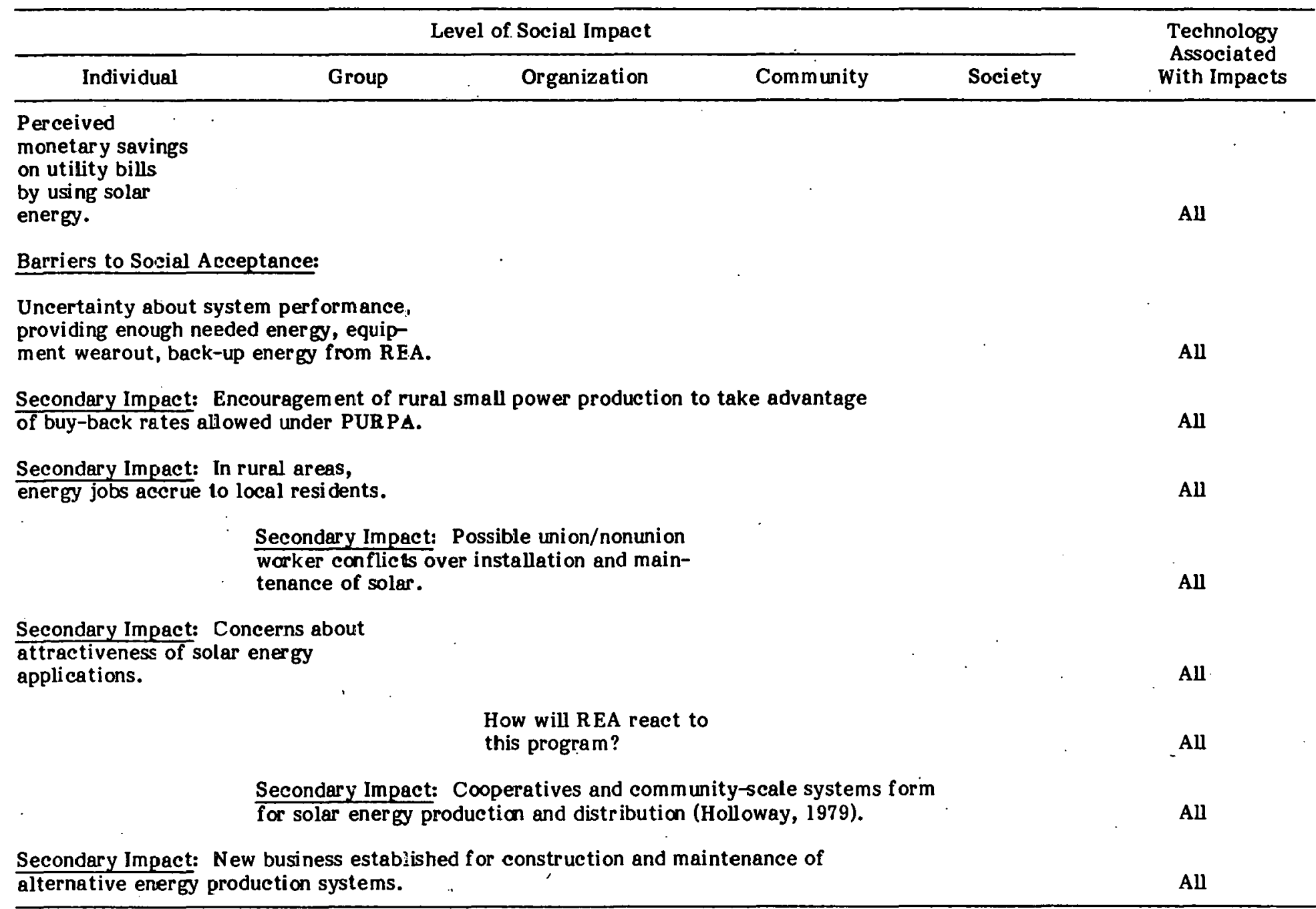


Table 5-7. SOCIAL IMPACTS OF THE POLCY NITLATVE APFECTING THE UTILTY SECTOR (Concluded)

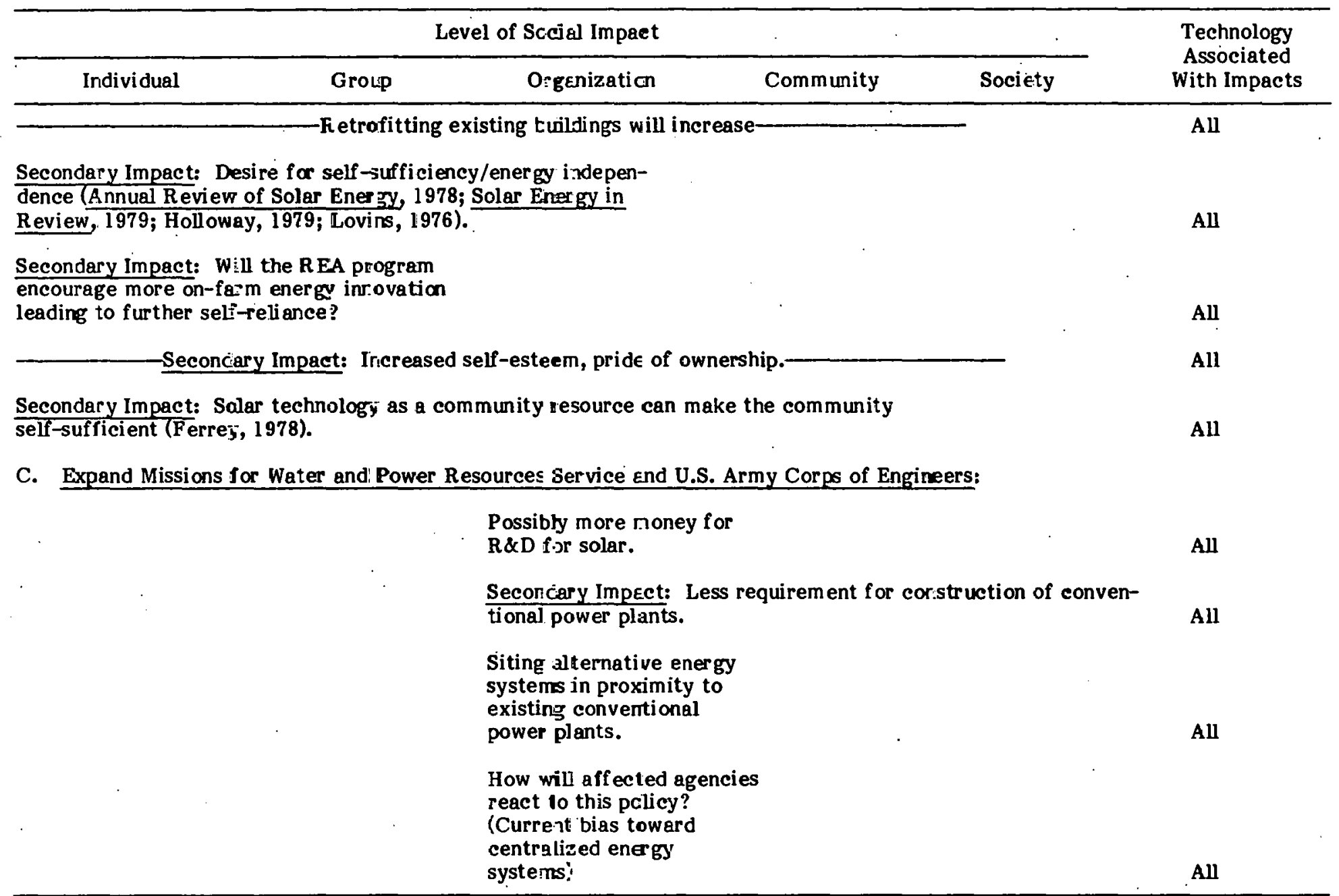

Possibly more noney for

Secorcigry Impect: Less requirement for corstruction of conventional power plants. 


\subsection{GOVERNMENT SECTOR INITIATTVES}

Two policy initiatives were proposed to enhance the use of solar energy in the government sector. One initiative concerned the Federal Government and the other was aimed at state and local governments. The federal initiative suggested a requirement that new civilian federal facilities use passive solar design and cost-effective active solar systems.

\subsubsection{New Civilian Federal Facilities}

This initiative proposed that all new civilian federal facilities be required to use passive solar design and construction techniques and active solar to the maximum extent possible. In addition, highly visible federal buildings would be retrofitted with solar water and space heating systems to supplement conventional systems. Under this proposal, U.S. Postal Service buildings would be retrofitted and a number of other public buildings that experience a high degree of use, such as rapid transit transfer stations and national park buildings, also would be retrofitted. Table 5-8 presents likely social impacts of implementing this initiative. 
Table 5-8. SOCIAL IMPACTS OP THE POLICY INITIATIVE TO REQUIRE NEW CIVILIAN FEDERAL PACIITIES TO USE PASSIVE SOLAR DESIGN AND COST EFPECTIVE ACTIVE SOLAR SYSTEMS*

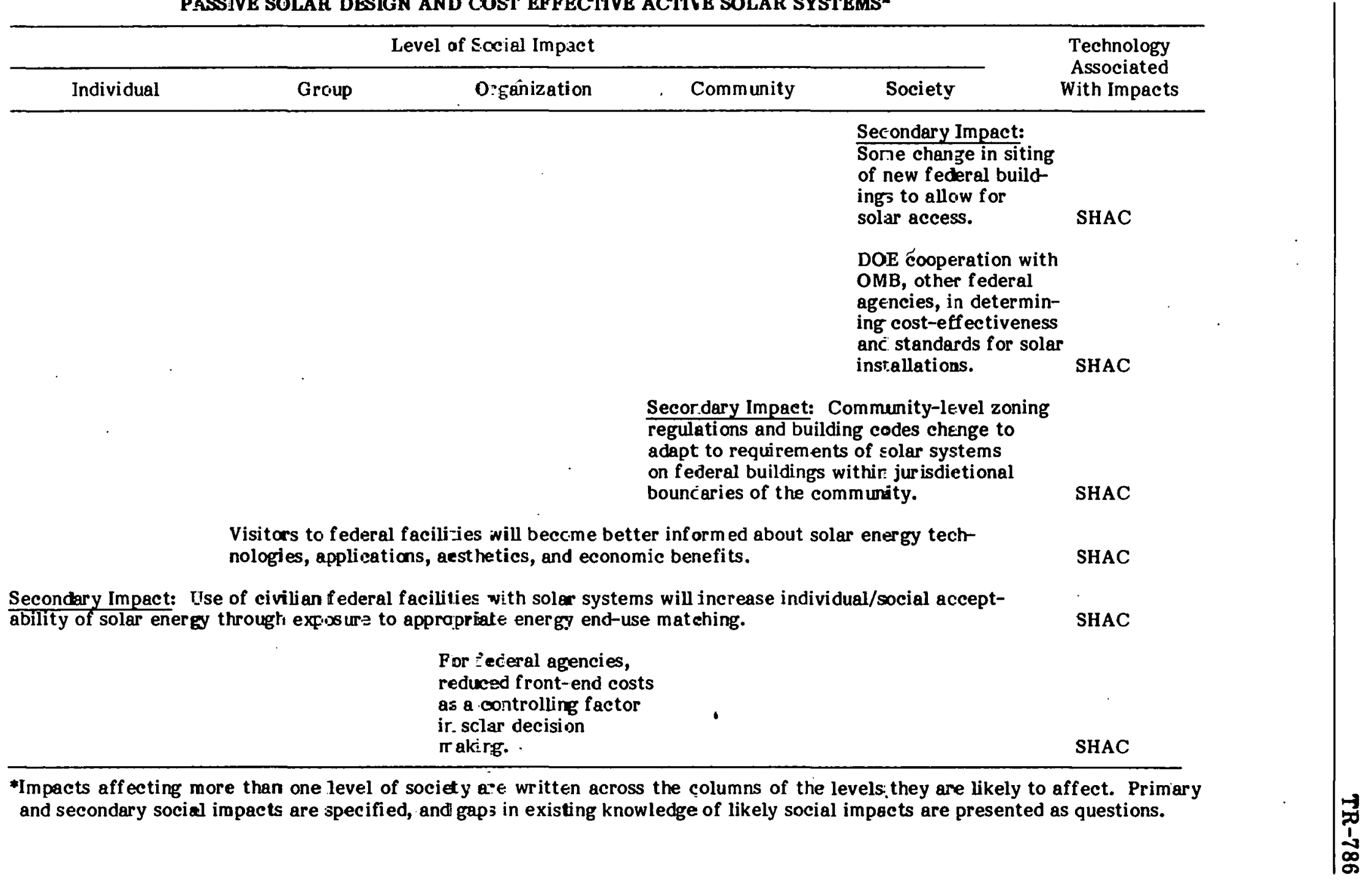


Table 5-8. SOCIAL IMPACIS OP THE POLCY INITIATIVB TO REQUIRE NEW CIVIIIAN PBDRRAL FACIITIES TO USB PASSIVE SOLAR DESIGN AND COST EFPECTIVB ACTIVB SOLAR SYSTBMS (Continued)

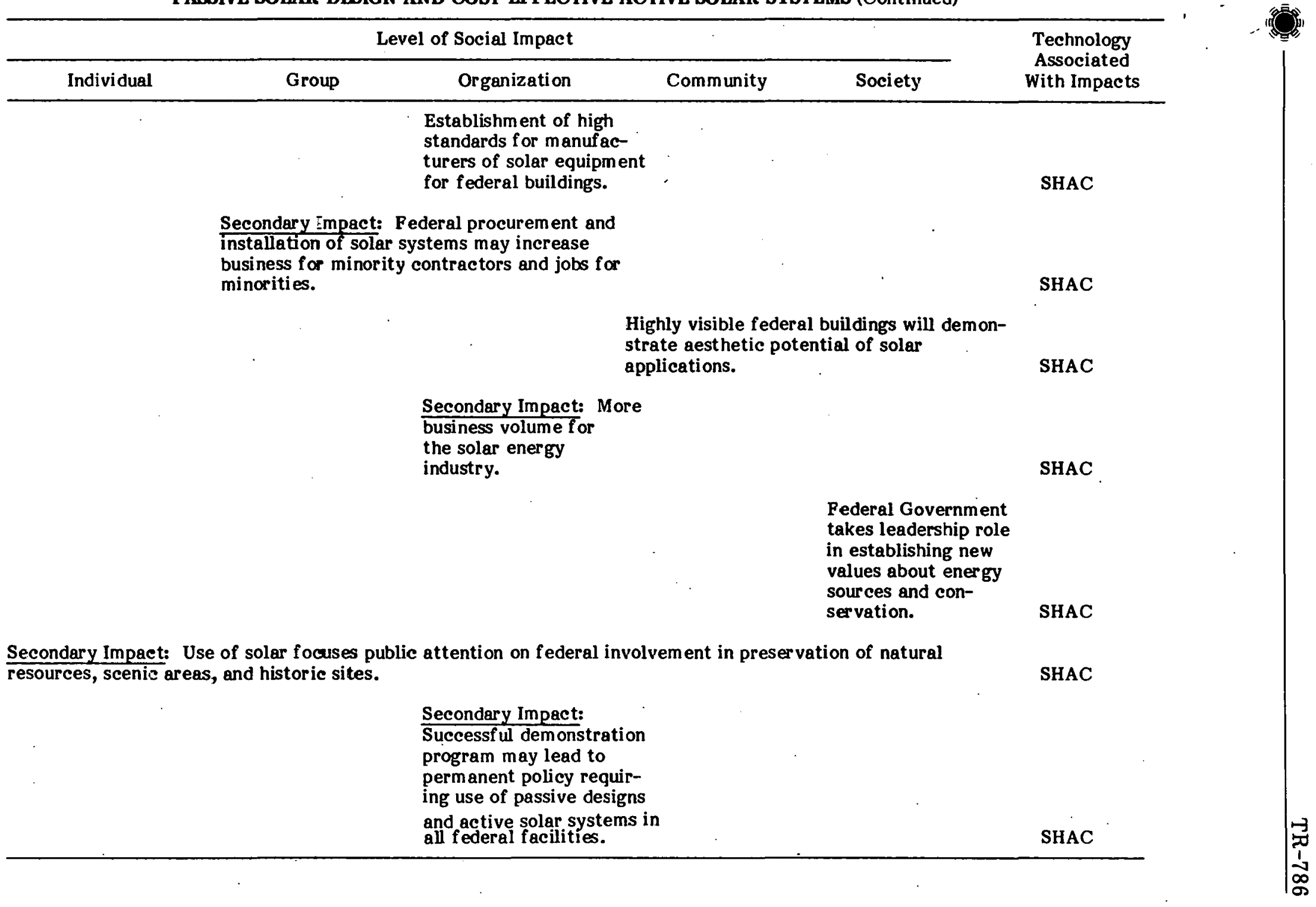


Table 5-8. SOCIAL IMPACTS OP THE POLICY INTTATIVE TO REQUIRE NEW CIVIIAN FEDERAL FACIITIES TO USE PASSIVB SOLAR DESIGN AND COST EFFECTIVB ACTIVE SOLAR SYSTEMS (Concluded)

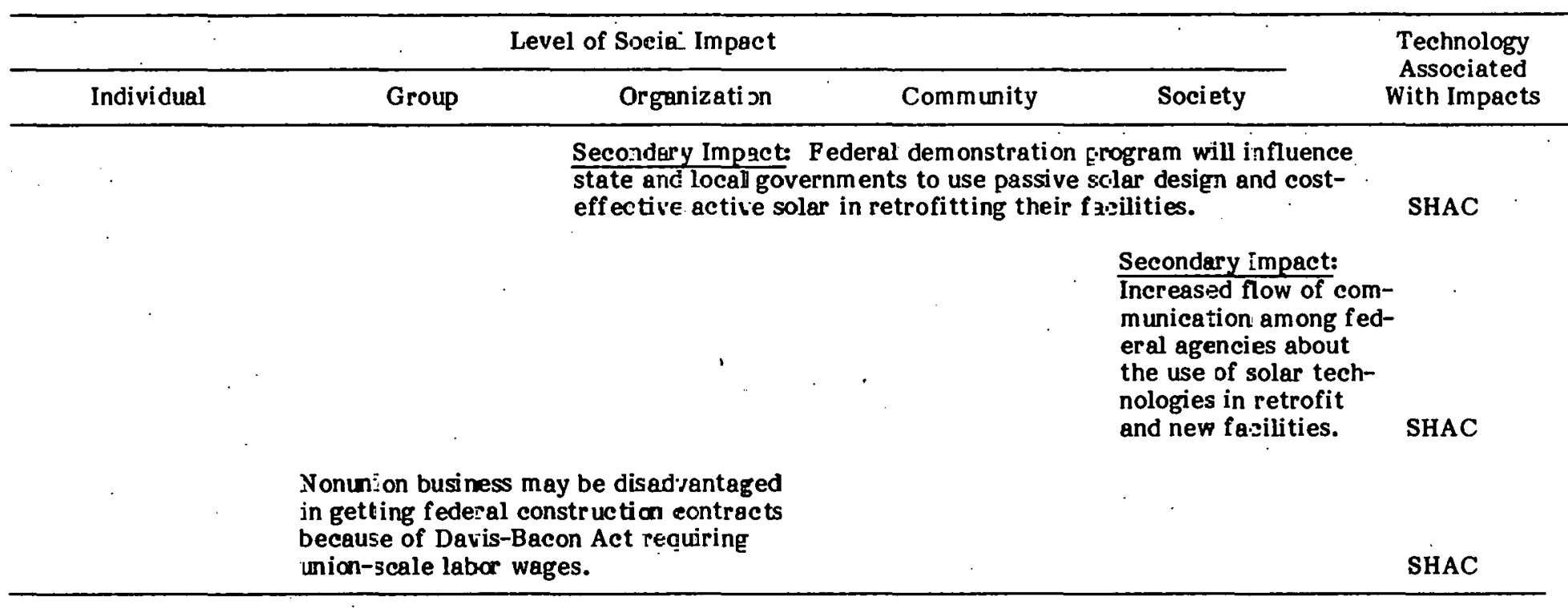




\subsubsection{State Energy Management Planning}

The second initiative to enhance the use of solar energy in the government sector is aimed at state and local government. The initiative calls for additional funds to be given to the states for energy planning and management. States would submit plans for the resolution of institutional barriers to solar energy use to qualify for matching federal grant money under the State Energy Management Planning Act (SEMP). Elements of the plans included goals for solar use; milestones for facilities using solar energy; methods for removal of regulatory and legal barriers associated with solar access and building codes; information programs for builders, lenders, and consumers; and programs for consumer protection. Federal grant money under SEMP would be made available for 5 years af ter enactment of the initiative. The likely impacts of this policy proposal are presented in Table 5-9. 
Table 5-9. SOCIAL IMPACTS OP THE POLICY INTIATIVB TO GIVE STATES ADDITYONAL PUNDS POR ENERGY PLANNING AND MANAGEMENT*

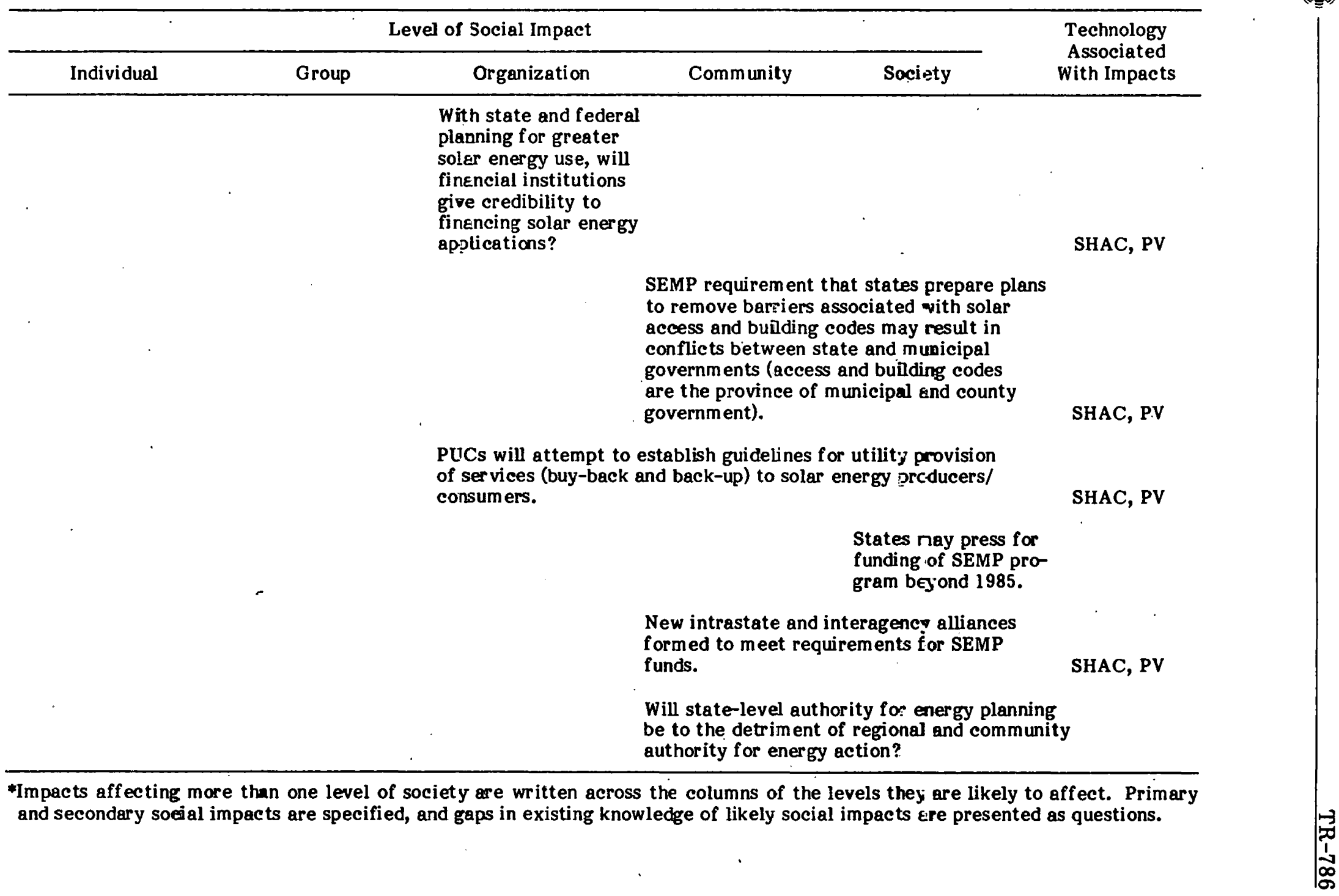


Table 5-9. SOCIAL IMPACTS OP THE POLICY INITLATIVB TO GIVE STATES ADDITIONAL PUNDS POR BNERGY PLANNING AND MANAGBMBNT (Continued)

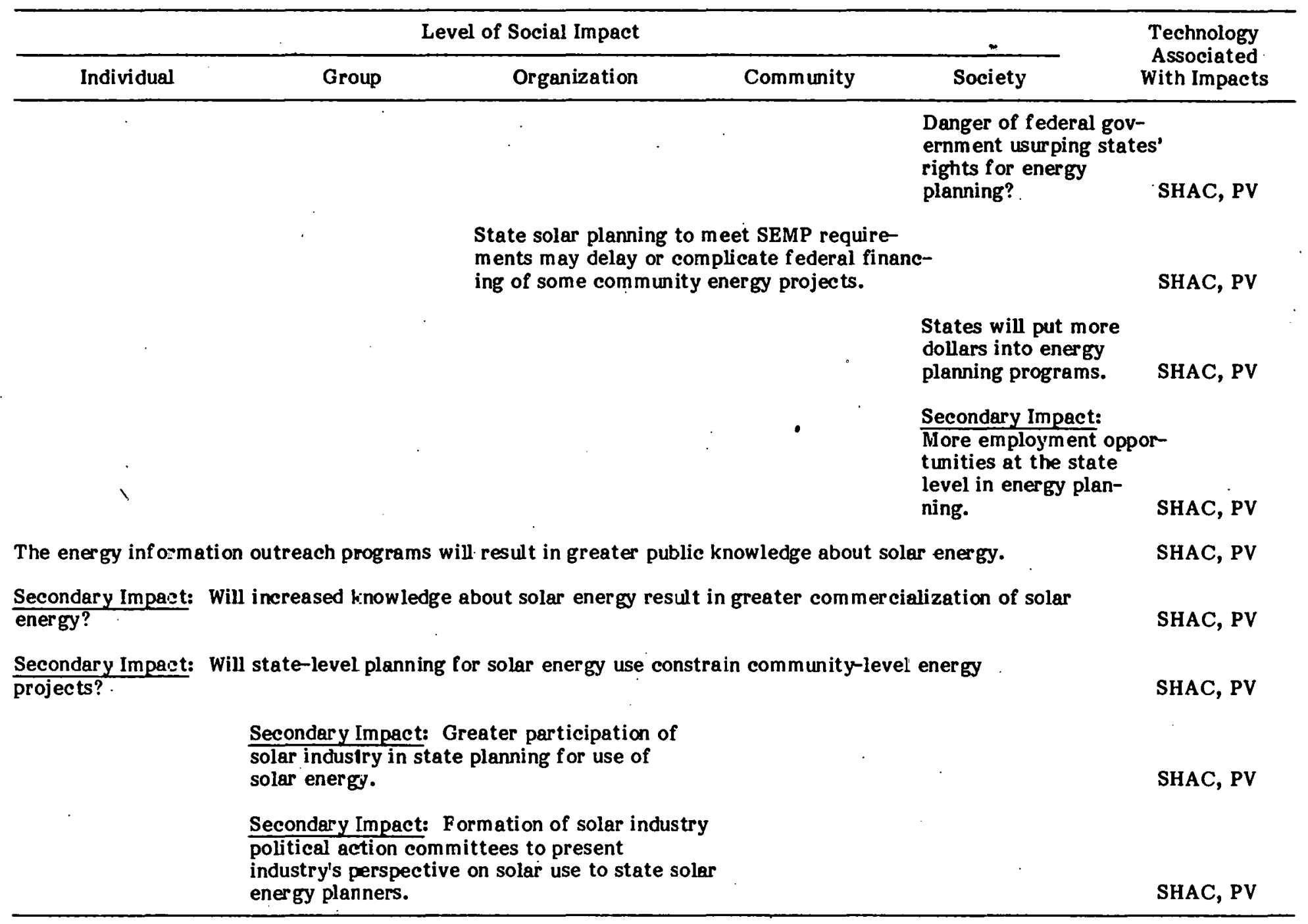


Table 5-9. SOCIAL IMPACTS OP THB POHCE INITIATIVE TO GIVE STATES ADDITIONAL FUNDS FOR ENERGY PLANNING AND MANAGRMENT (Eoncluded)

\begin{tabular}{|c|c|c|c|c|}
\hline \multicolumn{4}{|c|}{ Leved of Social Intpact } & \multirow{2}{*}{$\begin{array}{l}\text { Technology } \\
\text { Associated } \\
\text { With Impacts }\end{array}$} \\
\hline Individual & Crjanization & Community & Society & \\
\hline , & $\begin{array}{l}\text { Secondary Impact: Utilities end energy } \\
\text { companies respond to state sclar planning by } \\
\text { developing solar energy plaming and research } \\
\text { units. }\end{array}$ & - & & SHAC, PV \\
\hline
\end{tabular}




\section{SECTION 6.0}

\section{CASE APPLICATION: RESIDENTIAL RENTAL MARKET}

This section demonstrates the importance of identifying specific individuals and groups that will be investigated in social impact assessments. Here, we address the set of social groups that make up the residential rental market. This demonstration afforded investigators an opportunity to conduct a preliminary test of the assessment strategy and categories of social impacts used in the general study. The question that guided the demonstration was, "How would the proposed policy initiatives affect the set of social groups in the residential rental market?" We conclude that specifying social groups results in a meaningful assessment, and that effective policy for increasing solar energy use in rental housing considers the diversity of the rental market.

Following a brief characterization of the rental housing market, five of the proposed policy initiatives are assessed. Specific likely impacts of each initiative are presented in tabular form after the initiative is described and its relationship to the rental market discussed. The relevance of the set of policy initiatives for the residential rental market is noted in the summary at the end of this section.

\subsection{CHARACTERISTICS OF THE RENTAL HOUSING MARKET}

The residential rental sector comprises a significant portion of U.S. housing. In 1977, there were $26-1 / 2$ million rental units in the United States, representing $35 \%$ of the entire housing stock (Bureau of the Census, 1979). Also, renters now face the nation's lowest recorded vacancy rate-5\% (GAO, 1979). The market is typified by fewer housing starts, increasing condominium conversions, and abandonment. Rising utility costs are part of the cause, exacerbating trends of rapidly rising operating costs throughout the rental sector. According to a report to Congress by the General Accounting Office (GAO, 1979), the rental housing situation is one of emergency.

The rental sector, like the residential sector in general, is varied in its composition. Differences in building structure, geographic distribution, forms of ownership, and renter demographics pose diverse technical, institutional, and economic barriers to conservation and solar energy use in rental housing. Differences between owner-occupied and rental housing, and differences within the rental housing sector.itself, are important because they reflect the diversity in the residential sector. This implies that policies need to be carefully tailored to ensure the promotion of energy efficiency in all forms of housing.

\subsubsection{Building Structure}

Associating rental housing with only multifamily structures is a common misrepresentation of the rental sector. Multifamily structures with five or more units actually constitute only $38.5 \%$ of U.S. rental housing stock. Multifamily structures with from two to four units account for $27 \%$ of the stock; and single-family rentals, $31 \%$. Thus, rental housing is more than multifamily structures. 


\subsubsection{Regional Distribution}

Rental housing is spread fairly evenly throughout the United States, but regional variations do exist in the types of rentals available. For example, there are more singlefamily attached (30\%), two to four units (34\%), and large multifamily structures (33\%) in the Northeast than any other region. Yet, there are fewer single-family detached units (9\%) in the Northeast than any other region. In contrast, single-family detached units are in greater abundance (44\%) in the South than are single-family attached, two to four units, or large multifamily rentals. The types of available rental units affect both the technical problems and policy considerations required for promotion of solar energy and conservation in each region.

\subsubsection{Urban/Rural Profile}

Rental housing is concentrated in urban areas, and this has implications for urban energy policy. Approximately $82 \%$ of rental housing is located in urban areas while $65 \%$ of owner-occupied units are there. In many cities, rental units actually outnumber owneroccupied units. This implies that effective urban energy policy will incorporate measures to encourage conservation and solar energy use in rental housing.

\subsubsection{Age of Housing Stock}

One important difference between rental housing and owner-occupied housing is that the rental stock in the United States is older. Approximately $41.4 \%$ of the rental housing in use today was constructed before 1939. This figure compares with only $27.6 \%$ of the owner-occupied units constructed during the same period. The significance of this is that the age of housing is directly correlated with the energy efficiency of buildings. For instance, of the existing structures built before 1939, approximately $33 \%$ have no ceiling insulation, and $41 \%$ have no wall insulation (DOE, 1980, p. 23). Similar deficiencies in insulation are found in only $5 \%$ and $6 \%$, respectively, of the units built after 1975 . 'These deficiencies indicate that there are both a substantial need and opportunities for conservation and solar energy measures to improve the energy efficiency of a large proportion of the rental stock.

\subsubsection{Federal Assistance in Rental Housing}

Increasingly, the Federal Government has been pressured to fill the supply gap in rental housing created when the private sector's investment in new starts decreased. Increasing operating costs, largely the result of escalating fuel prices, have reduced the profitability of all rental housing, especially low-income rentals. Investment in new multifamily housing has fallen dramatically, as private investments hit a 20-year low (GAO, 1979, p. 11). While the number of annual multifamily housing starts decreased from 906,000 in 1972 to 371,000 in 1977, federal subsidies have doubled from $22 \%$ to $44 \%$. HUD has estimated that by 1980 nearly $60 \%$ of multifamily construction would be federally subsidized, and more than $75 \%$ will be subsidized or federally insured, or both (GAO, 1979, p. 25). The decrease in rental housing starts can further aggravate the currently tight rental housing market, and increasing federal involvement in rental housing can become a severe burden on federal resources. This situation suggests the appropriateness of a federal role in encouraging energy-efficient construction in federally sponsored rental housing starts. 


\subsection{ENERGY USE PATTERNS}

Space heating (50\%) and domestic water heating (30\%) account for approximately $80 \%$ of the energy consumed in both the rental and owner-occupied sectors. The proportions of heating fuels used for space heating in both rental and owner-occupied dwellings are also fairly comparable. The two most significant differences between renters and homeowners are (1) the greater percentage of renters (17.4\%) who have electric space heating and (2) the greater percentage of renters having no heating at all (1.1\%).

A significant variability exists in the regional distribution of the four most of ten used fuel sources for residential space and water heating. While both the West and the North Central regions used gas space and water heating predominantly, the South used about the same quantity of electricity as gas for space heating but more electricity than gas for hot water. The Northeast used more fuel oil than gas for space heating. This suggests that the fuel needs for residential space and water heating are not the same for all regions of the nation, and this variety must be considered in the debates about energy use.

\subsection{WHO PAYS THE ENERGY BILLS?}

Another crucial distinction in the rental housing sector is who pays for the energy used to heat water and space. The percentage of space and water heating utility bills paid by the building owner and usually passed on to the tenant in the rent (master-metered) as opposed to those paid directly by the tenant (separately metered) varies by fuel type, building structure, and region. In general, electricity is almost always paid directly by the renter, and fuel oil bills are usually paid by the owner and covered in the rent. Gas, on the other hand, while usually paid.by the tenant, is more of ten paid by the owner than is electricity.

When the tenant is paying the utility bills, there is very little, if any, incentive for the owner to invest in conservation or solar energy equipm ent, or both, because owners see no immediate economic benefits. Likewise, when an owner can readily pass on $100 \%$ of rising energy costs, there is little incentive to invest in conservation or solar energy. It seems owners have the greatest incentive to invest in conservation and solar energy when they still pay energy bills themselves, and for some reason are unable to pass on the full cost to the tenants in their rents.

All of these differences between the rental and owner-occupied portions of the residential sector are important because they suggest the necessity for carefully tailored policies and programs that do not inisrepresent the residential sector as homogeneous. At the same time, it is crucial for policy makers to understand that great diversity exists within the rental sector itself.

\subsection{PRINCIPAL GROUPS IN THE RENTAL HOUSING MARKET}

For policies and programs to encourage solar energy use and conservation effectively in rental housing, policy makers must understand the decision-making process in rental housing and address its diversity of physical characteristics. Policies and programs must incorporate knowledge of chief groups in the rental housing market and how they are likely to respond to such policies and programs. These groups include renters, builders, and owners. 


\subsubsection{Renters}

Renters generally have lower incomes than homeowners (see Table 6-1). In 1977 the median income of a renting family was only $\$ 8,800$, but the income of the average homeowner was $\$ 16,000$. As a consequence, a greater proportion of the income of renters is spent for rising energy costs which they pay either through rent increases or directly as utility bills. Although low-income households consume less energy than the national average, they spend $30 \%$ to $40 \%$ of their incomes for energy, while middleincome households in identical climates spend $7 \%$ to $10 \%$ of their incomes for energy (NCAT, p. 12).

Table 6-1. INCOME COMPARISON: HOMEOWNERS VS. RENTERS, 1977

\begin{tabular}{lcccc}
\hline \multicolumn{1}{c}{ Income (\$) } & No. of Homeowners & Percentage & No. of Renters & Percentage \\
\hline$<7,000$ & 9,469 & $19.4 \%$ & 10,723 & $40.4 \%$ \\
$7,000-10,000$ & 4,797 & 9.8 & 4,232 & 16.0 \\
$10,000-15,000$ & 8,571 & 17.6 & 5,328 & 20.1 \\
$\geqslant 15,000$ & $\underline{25,929}$ & $\underline{53.2}$ & $\underline{6,232}$ & $\underline{23.5}$ \\
\multicolumn{1}{c}{ Total } & 48,766 & 100.0 & 26,515 & 100.0 \\
\hline
\end{tabular}

Source: GAO, p. 8.

Renters are also less likely to invest in conservation or solar energy than homeowners. Besides all the legal and financial difficulties renters have in investing in conservation or solan energy devices for another's property, renters usually have less money to invest in such measures. Also, in general, low-income renters occupy the least energy-efficient structures. Of the 11 million rental units constructed before $1939,64 \%$ are occupied by families earning under $\$ 10,000$ (Bureau of the Census, 1979). In sum, these characteristics of renters suggest they are in the greatest need of help in paying energy bills.

Most rental housing tenants pay their own utility bills directly but can make only minimal investments in conservation and solar energy. Small investments with payback periods shorter than a lease or investments in portable devices such as low-flow shower heads that the renter can take when moving are of limited value in reducing utility bills. Also, there are restrictions on these conservation efforts. In addition to financial constraints faced by low-income renters, there are legal restraints that forbid tenants from tampering with rented property without the owner's permission. Although owner/tenant cooperation is probably easiest with portable devices, more expensive investments such as insulation or a solar water heater, which require substantial changes in rental property, are likely to meet with greater resistance from owners.

Because tenants are severely constrained from taking responsibility for conservation or solar energy investments, energy policies and programs must focus on rental housing owners. The following section explains how rental housing owners evaluate investments, and how they can be encouraged most effectively to invest in energy-efficiency improvements. 


\subsubsection{Owners}

Operating costs for building owners and managers are increasing at a more rapid rate than are the revenues collected in the form of rents. In a study for HUD, Touche, Ross and Company reported that, since 197.0, fuel and utility expenses have increased $98 \%$ in apartment buildings while rents have increased only $39 \%$ (Booz, Allen \& Hamilton, 1979). Owners are responding to declining profitability with condominium conversions and, in some cases, abandonment. These reactions remove housing units from the rental market, further exacerbating the acute shortage in rental housing.

Investors and building owners select the forms of ownership (proprietorship, partnership, or corporation) most profitable for them based on their existing assets, tax liabilities, and general portfolios. The individual investor or building owner will also have preferences for the types of profit (annual income, tax benefits, and/or capital gain) most beneficial to her or his financial situation. Forms of ownership and types of profit interact, and individuals investing in or owning rental housing will select the combination that is most beneficial and most profitable for them (Harvard Business School, 1972).

To be most effective, financial incentives should be of the type preferred by rental housing owners. As reported by Booz, Allen \& Hamilton (1979), a National Apartment Association (NAA) survey of rental housing owners (five or more units per building) indicated a strong preference for tax credits and a strong dislike for loan guarantees and grants. In almost every form of ownership, a substantial portion of profits from owning rental property is in the form of tax benefits. Rental property owners are, therefore, familiar with the tax system, and it is not surprising that they prefer tax credit incentives over loan guarantees or grants which require greater government involvem ent in their operations.

In addition, the NAA survey found that criteria for cost-effectiveness in energy-related investments are high. The majority (72\%) of owners surveyed indicated they would make an investment in conservation and solar energy if the payback period were 3 years or less. This is a serious barrier to some conservation and most solar energy investments because payback periods are generally longer than 3 years. When conservation and solar energy investments are evaluated on a life-cycle cost basis, they are of ten competitive with conventional fuels and appear to be sound investments. However, if owners have a maximum 3-year payback period requirement, it would be difficult for them to perceive such an investment as cost-effective or financially sound.

Another important problem reducing the likelihood of energy-related investment is that building owners have little basis on which to judge and calculate the cost-effectiveness of an investment, because they are uncertain about how much conventional fuel they will save or the future value of that fuel. Uncertainty about fuel and monetary savings is a major barrier to investments in conservation and solar energy for rental housing (Booz, Allen \& Hamilton, 1979).

\subsubsection{Builders}

Builders of rental housing are fundamentally similar to owners. They have few incentives to invest in conservation or solar energy in rental housing. First, because rental housing starts are at an all-time low, builders' business has declined. Second, builders can be short of capital at the time of construction and so usually will choose the least expensive heating equipment. Since builders do not usually own or operate their buildings, they have little concern for future utility operating costs. This is evidenced by the fact that 
most new rental housing is equipped with electric resistance space heating. Electric resistance heating is the least expensive system to install, but the most expensive and inefficient method of heating in all regions of the country.

\subsubsection{Summary}

While tenants may have an economic incentive to conserve energy and use solar energy to keep utility payments down, they have little income available for such investments and are legally constrained from making unauthorized improvements to rental property. In contrast, builders and owners have more expendable income with which to make investments in conservation or solar energy. However, because they share little or no responsibility for paying utility bills, there is no economic incentive for those investments.* In the next section, we explore federal policies that have been suggested to encourage solar energy use in the residential sector in general. These policies will be analyzed as to their likely effectiveness in the rental housing sector.

\subsection{SOCIAL IMPACTS OF POLICY INITIATIVES}

In this section, we explore likely social impacts of five of the proposed national-level public policies presented and investigated in Sec. 5.0. These policies have relevance to the residential sector as a whole. The five policies are:

- a tax credit for energy-efficient construction;

- the formation of a Solar Development Bank;

- federal funding for solar programs for the poor;

- a consumer protection program; and

- extension of the solar tax credit to include leased solar cquipment.

Each policy initiative was assessed independently, and the results are presented separately here. Each policy is introduced with a general description of the initiative, a statement about its likely impact on rental housing, and an assessment of impacts on the groups associated with the market. Following each introduction is a table that outlines likely impacts by category of social impact and by social groups within the residential rental market. The major groups referred to are builders, owners, and tenants. Other groups affected are listed in a fourth column, labeled "Other." The impacts presented are not rank-ordered and do not suggest how significant each will be. Also, interaction effects among the impacts are not assessed.

\subsubsection{Tax Credit for Energy-Efficient Construction}

This policy would allow an income tax credit to builders based on the number of Btu saved compared with conventional construction. We will presume an estimated credit to equal about $\$ 1,000$ per dwelling unit. The credit would be in effect for 5 years. It is

*In addition, from the owner's perspective, a conservation or solar energy investment is not perceived as cost-effective because of uncertainty in calculating return and the high return required. 
unclear whether the credit would be available to contractors performing substantial building rehabilitation.

It is estimated that $75 \%$ of rental housing starts today, which are at an all-time low, are federally subsidized or insured (GAO, 1979). Therefore, federal requirements for energyefficient construction in new rental housing could have a bigger impact than would a tax credit. However, without adequate financing for energy-efficient construction, such requirements could cause rental housing starts to decline even further. Likely social impacts of this initiative are specified in Table 6-2. 
Table 6-2. SOCIAL IMPACTS ON RESIDENTIAL RENTAL GROUPS OF A TAX CREDIT FOR ENERGY-EFFICIENT CONSTRUCTION

\begin{tabular}{|c|c|c|c|c|c|}
\hline & $\begin{array}{l}\text { Categories of } \\
\text { Social Impacts }\end{array}$ & Builder & Owner & Tenant & Other \\
\hline 1. & $\begin{array}{l}\text { Financial Aspects of } \\
\text { Solar Energy Deci- } \\
\text { sion Making }\end{array}$ & 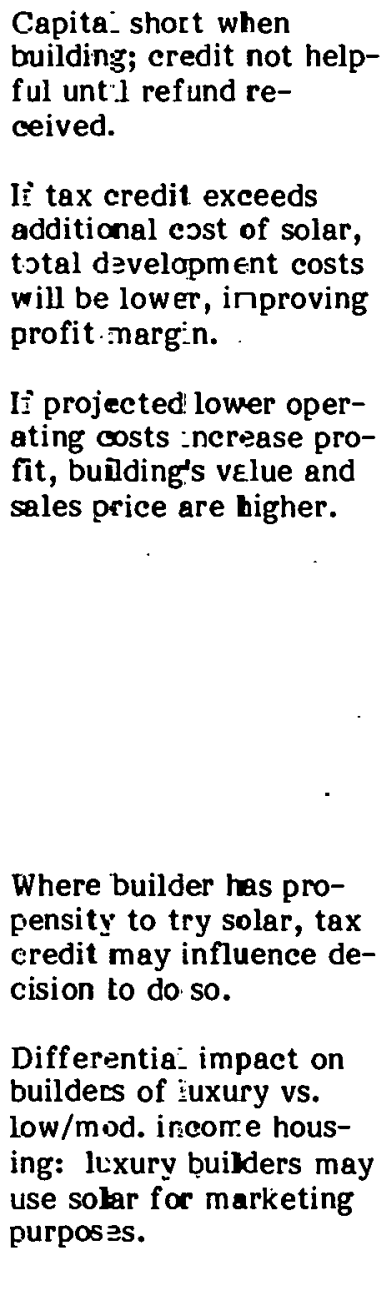 & $\begin{array}{l}\text { Annual operating income } \\
\text { higher, expenses lower } \\
\text { for fuel. } \\
\text { Secondary Impact: } \\
\text { Higher building purchase } \\
\text { price to owner (buyer). } \\
\text { Secondary Impact: If } \\
\text { owner is Public Housing } \\
\text { Authority, less public } \\
\text { dollars required to pay } \\
\text { heat and rent. } \\
\text { Secondary Impact: } \\
\text { Less turnover due to en- } \\
\text { ergy costs: } \\
\text { - increase profit by re- } \\
\text { ducing vacancy costs; } \\
\text { - decrease profit in } \\
\text { cases where rent con- } \\
\text { trol allows rent in- } \\
\text { crease only with unit } \\
\text { change of occupancy. }\end{array}$ & $\begin{array}{l}\text { Lower utility experses. } \\
\text { whether included ir. rent } \\
\text { or not. } \\
\text { Secondary Impact: May } \\
\text { have higher rent gener- } \\
\text { ally because of building's } \\
\text { increased value. } \\
\text { Unequal tenant access } \\
\text { to solar-heated space. } \\
\text { Secondary Impact: Less } \\
\text { turnover attributatle to } \\
\text { energy costs in energy- } \\
\text { efficient apartments. }\end{array}$ & $\begin{array}{l}\text { Secondary Impact: } \\
\text { Banks reluctant to make } \\
\text { loans for solar because } \\
\text { "collateral" based on tax } \\
\text { credit. } \\
\text { Secondary Impact: } \\
\text { Banks willing to loan } \\
\text { more for solar construc- } \\
\text { tion if convinced that } \\
\text { profit increases. }\end{array}$ \\
\hline
\end{tabular}


Table 6-2. SOCIAL IMPACTS ON RESIDENTIAL RENTAL GROUPS OF A TAX CREDIT POR ENERGY-EFFICIENT CONSTRUCTION (Continued)

\begin{tabular}{|c|c|c|c|c|}
\hline $\begin{array}{l}\text { Categories of } \\
\text { Social Impacts }\end{array}$ & Builder & Owner & Tenant & Other \\
\hline . & $\begin{array}{l}\text { Luxury building builders } \\
\text { with higher profit mar- } \\
\text { gin have more expend- } \\
\text { able income for solar. } \\
\text { Credit in income tax } \\
\text { means more ro luxury } \\
\text { rental builders with } \\
\text { more income. } \\
\text { No impact on nonprofit } \\
\text { developer. } \\
\text { Secondary Impact: } \\
\text { Builders influence banks } \\
\text { to finance solar and en- } \\
\text { ergy-efficient construc- } \\
\text { tion so that tuilders can } \\
\text { take tax credit. }\end{array}$ & $\begin{array}{l}\text { Owner perceives energy- } \\
\text { efficient building as bet- } \\
\text { ter invest ment. }\end{array}$ & $\begin{array}{l}\text { Secondary Impact: Ten- } \\
\text { ants prefer to live in en- } \\
\text { ergy-efficient building. }\end{array}$ & $\begin{array}{l}\text { Secondary Impact: } \\
\text { Banks change policies to } \\
\text { be more favorable to } \\
\text { energy-efficient con- } \\
\text { struction demand. }\end{array}$ \\
\hline $\begin{array}{l}\text { 2. Behavior Related to } \\
\text { Solar Energy Use }\end{array}$ & $\begin{array}{l}\text { Change in conventional } \\
\text { building prac-ices. } \\
\text { Builders familliarize } \\
\text { themselves with energy- } \\
\text { efficient construction } \\
\text { techniques. }\end{array}$ & $\begin{array}{l}\text { Owners familiarize } \\
\text { themselves with energy- } \\
\text { efficient construction } \\
\text { techniques in order to } \\
\text { evaluate investment. } \\
\text { Secondary Impact: For } \\
\text { passive solar, owners } \\
\text { keep windows clean; in- } \\
\text { creased maintenance } \\
\text { responsibilities. }\end{array}$ & $\begin{array}{l}\text { Secondary Impacts: } \\
\text { Changes in routine pat- } \\
\text { terns of behavior asso- } \\
\text { ciated with energy use } \\
\text { (i.e., pulling shades, } \\
\text { etc.). }\end{array}$ & . \\
\hline
\end{tabular}


Table 6-2. SOCIAL IMPACTS ON RESIDENTIAL RENTAL GROUPS OF A TAX CREDIT FOR ENERGY-EPFICIENT CONSTRUCTION (Continued)

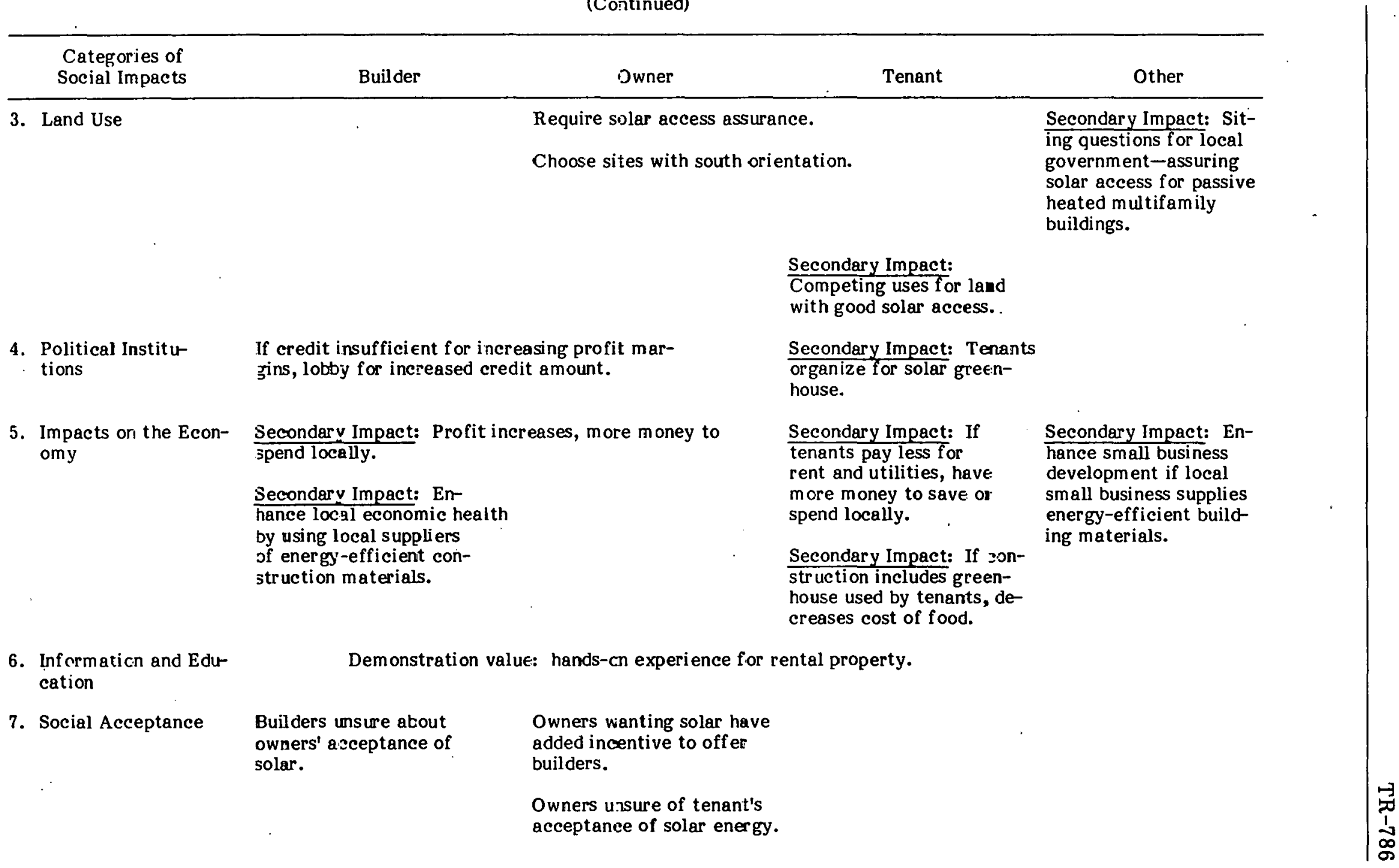


Table 6-2. SOCIAL MMACTS ON RESIDENTIAL RENTAL GROUPS OP A TAX CREDIT FOR ENERGY-EPFICIENT CONSTRUCTION (Continued)

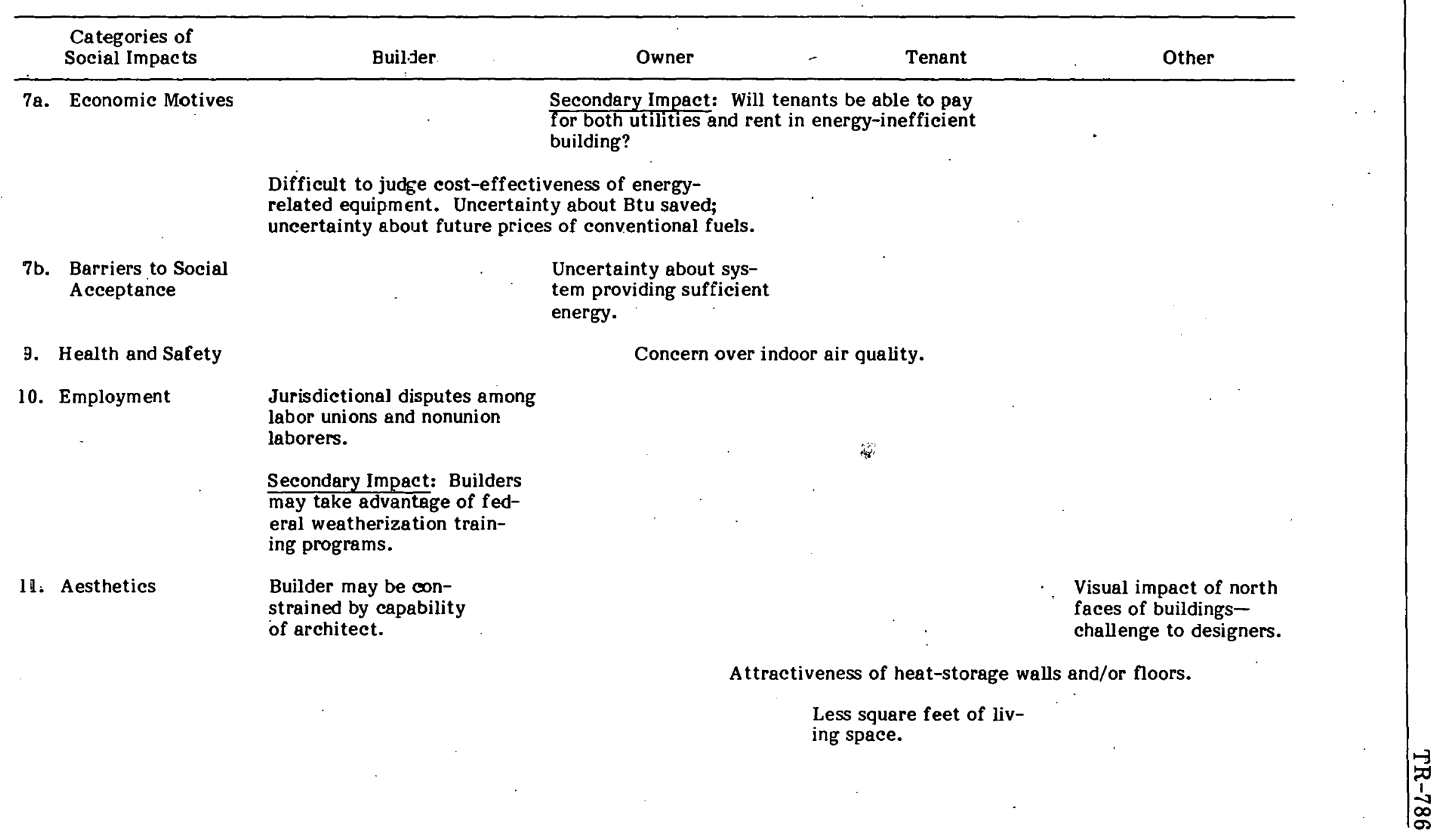


Table 6-2. SOCIAL IMPACTS ON RESIDENTIAL RENTAL GROUPS OP A TAX CREDIT POR ENERGY-EPFICIENT CONSTRUCTION (Concluded)

\begin{tabular}{ccccc}
\hline $\begin{array}{c}\text { Categories of } \\
\text { Social Impacts }\end{array}$ & Builder & Owner & Tenant & Other \\
\hline
\end{tabular}

Trade-off betweer! best view and best solar orientation.

New design opportu-

nities for federally

supported rental hous-

ing.

12. Impacts on Industry

Energy pricing for bazk-up may be higher/Btu with

lower energy use.

13. Quality of Life

Secondary Impact: Feeling of being unique, innovative.

Secondary Impact: Greater sense of autonomy and and self-sufficiency.

Secondary Impect: Contribution to national energy security. 


\subsubsection{Solar Development Bank}

In August 1980, Congress authorized a Solar Development Bank. Here, we explore the impacts of the Bank as created by law rather than as proposed in the policy initiative. The Bank will buy solar-related loans from conventional lending institutions, subsidizing the interest on portions of the loans depending on the loan recipient's income. In the case of rental housing, it is assumed that renters will be unlikely to use the loans because of the constraints on their ability to make changes to rental property. Builders and owners will be more likely to use the Bank. However, because of their generally high incomes, the loan recipients will be eligible for only $40 \%$ subsidies. In addition, that portion of the solar energy investment that is subsidized through the Bank is not eligible for the federal tax credit. Assuming that builders and owners of rental property have access to conventional financing, the Solar Bank loan subsidy is nearly equivalent to the tax credit but provides little incentive to builders or owners to incorporate solar energy systems in rental housing. Likely social impacts are presented in Table 6-3. 
Table 6-3. SOCIAL IMPACTS ON RESIIENTIAL RENTAL GROUPS OF A SOLAR DEVELOPMBNT BANK

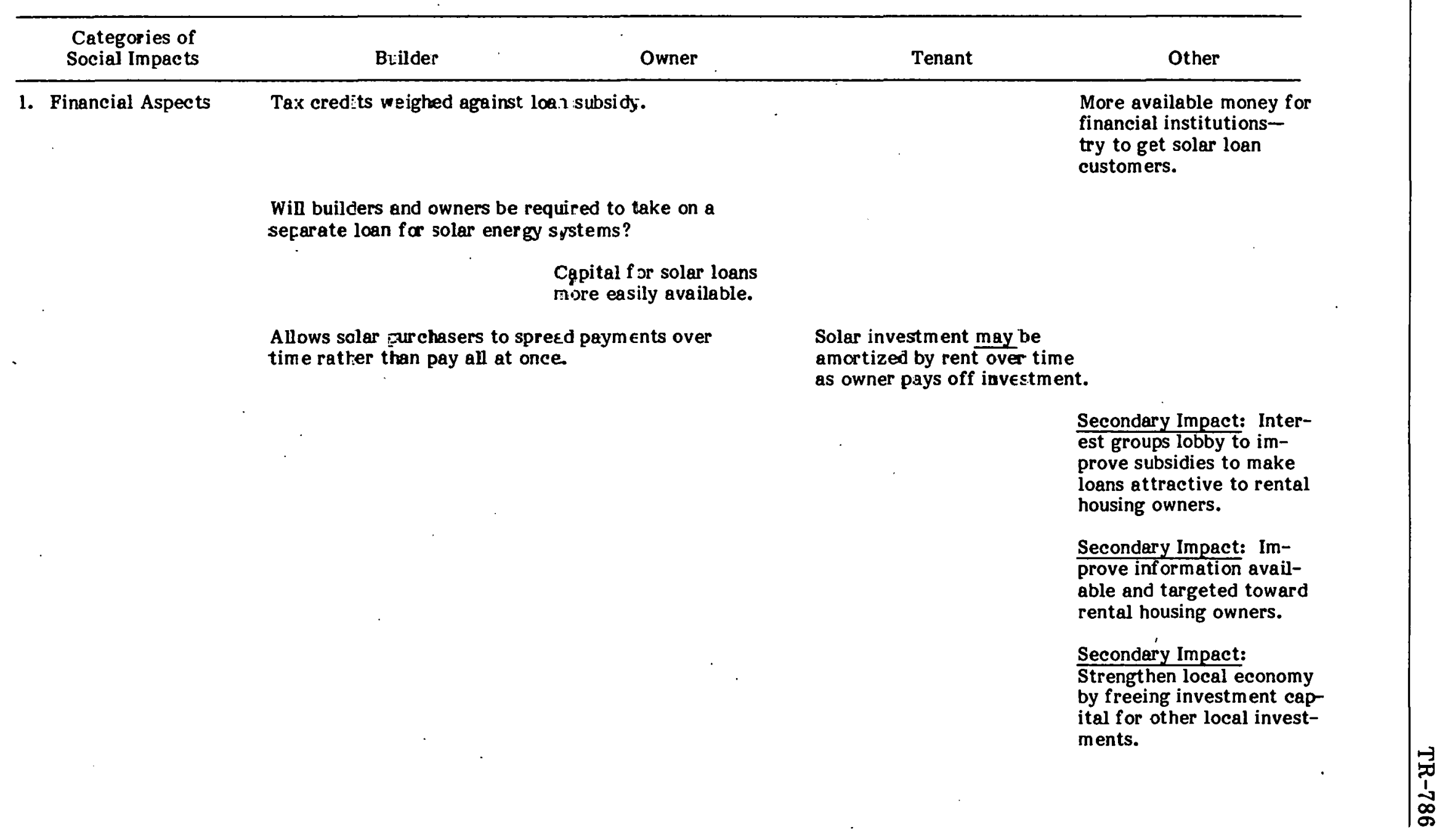




\subsubsection{Punding Program to Assist Low-Income Groups}

This policy has two major parts. The first part would provide grants to low-income hom eowners for solar energy systems. The second part of the program would increase public housing construction financing by $20 \%$ to cover the cost of solar prototype construction and provide funding for public housing and Section 8 unit retrofits. Grants for prototype public housing construction are likely to have a small impact on the rental housing market because there are so few rental housing starts and because public housing makes up a small portion (13\%) of all rental housing. Federal subsidies for rental housing are more prominent in privately owned units. Therefore, grants for Section 8 and public housing retrofits may have a bigger impact on rental housing, especially because Section 8 units are of ten mixed with unsubsidized units in the same building. Three divisions of impacts are suggested by this policy and are presented in Table 6-4. First, Program 1 impacts of the $80 \%$ grants for low-income homeowners are presented. Then, Program 2 impacts are presented in two sections: impacts of an increase in level of subsidies as construction costs for solar prototypes and impacts for Section 8 housing retrofits. 
Table 6-4. SOCLAL IMPACTS ON RESIDENTIAI, RENTAL GROUPS OP FEDERAL PUNDING OF LOW-DNCOME HOUSING

\begin{tabular}{|c|c|c|c|c|}
\hline $\begin{array}{l}\text { Categories of } \\
\text { Social Impacts }\end{array}$ & 3uilder & Owner & Tenant & Other \\
\hline
\end{tabular}

Program 1: $80 \%$ grants for low income homeowners to purchase and install solar energy systems:

\section{Behavior Related to}

Solar Energy

13. Quality of Life

Бे

\author{
Encourage tenants tc \\ form cooperatives or en- \\ courage condominium con \\ version of their rental \\ units.

Secondary Impact:
Poorer tenants unable to
aff ord unit once it is
converted to co-op or
condo.

Encourage rehabitation of abandoned buildings

as co-ops.

Secondary Impact:

Further rental housing shortage.

Program 2: Increase public housing construction funds for solar prototypes:
1. Financial Aspects
Provides funds to builders interested in constructing prototype solar public
housing.

\section{Lessens cost to taxpayers of operating public hous- ing through decreased util- ity expenses.}

11. Aesthetics

\begin{abstract}
Expands design opportuni-
\end{abstract} ties for putlic housing.

4. Political Institutions

Public housing juilders lobby to exand the program.
Secondary Impact: Public housing more attractive to live in.

Delay construction of public housing for design review.
Secondary Impact Communities lobby to require solar and energy-efficient construction in public housing to reduce their costs of maintenance and operation. 
Table 6-4. SOCIAL IMPACTS ON RESIDENTIAL RENTAL GROUPS OP PEDERAL PUNDING OF LOW-INCOME HOUSING (Continued)

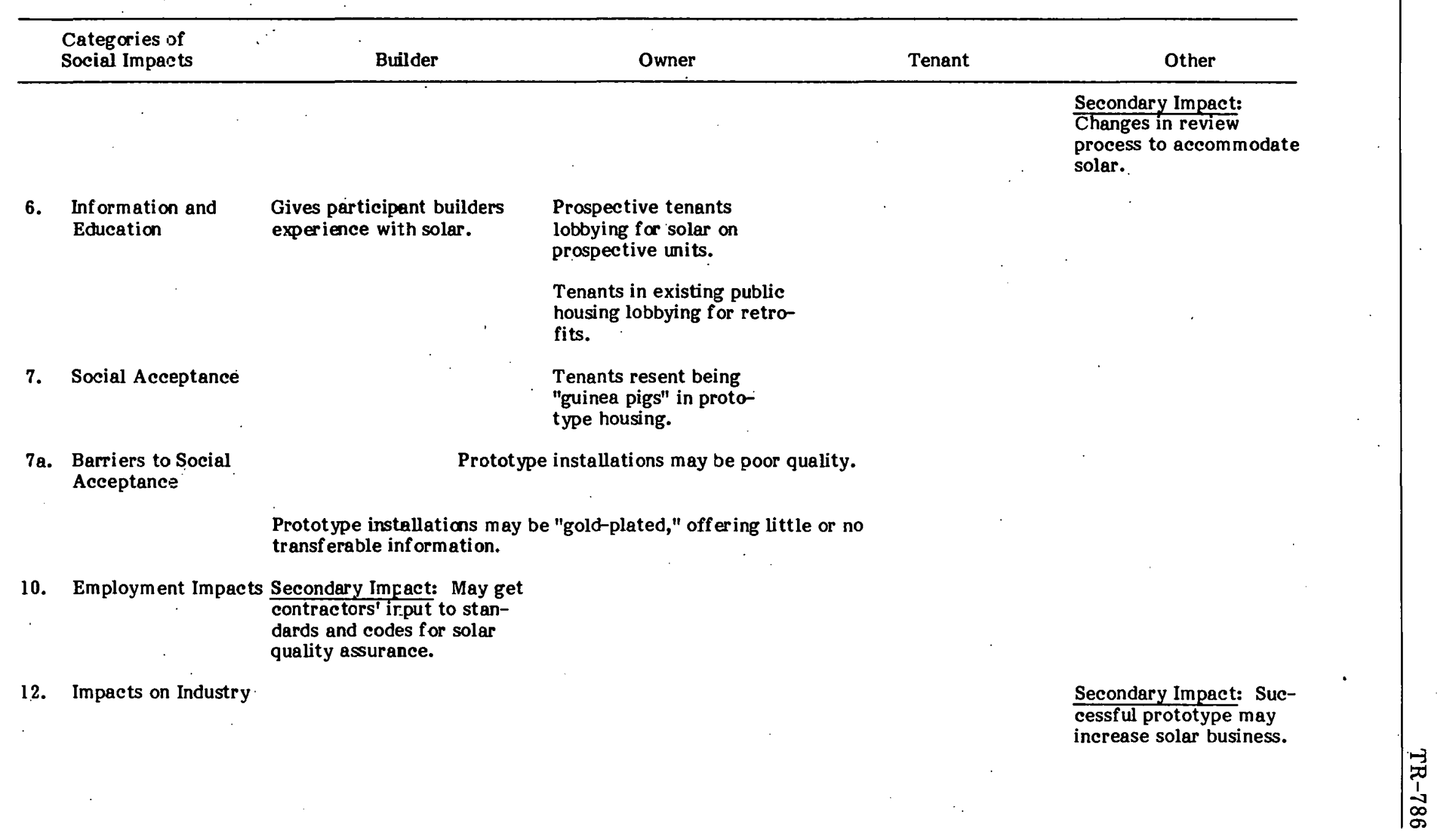


Table 6-4. SOCIAL IMPACTS ON RESIDENTIAL RENTAL GROUPS OF FEDERAL FUNDING OF LOW-INCOME HOUSING :Continued)

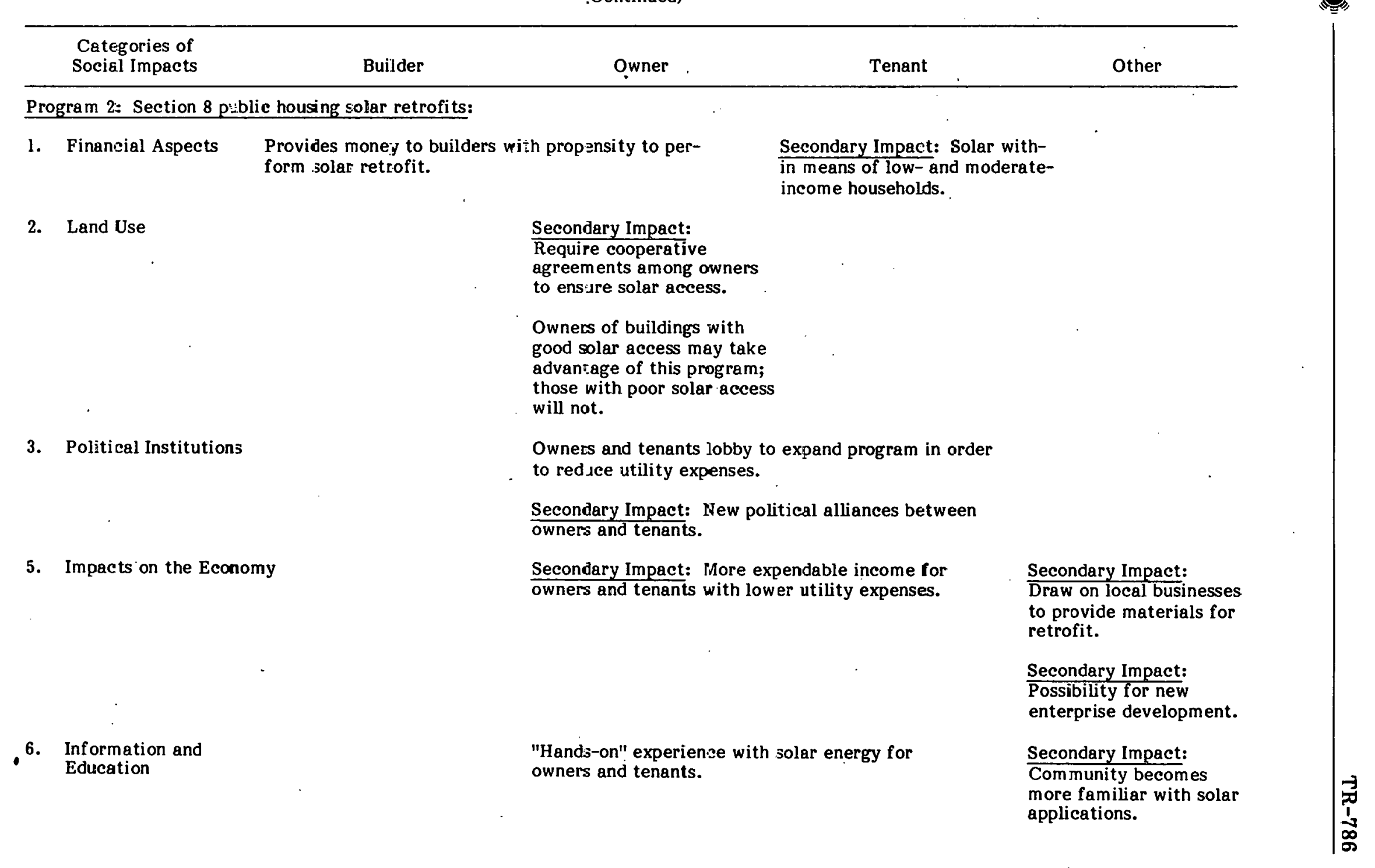


Table 6-4. SOCIAL IMPACTS ON RESIDENTIAL RENTAL GROUPS OF FEDERAL FUNDING OF LOW-DNCOME HOUSING (Concluded)

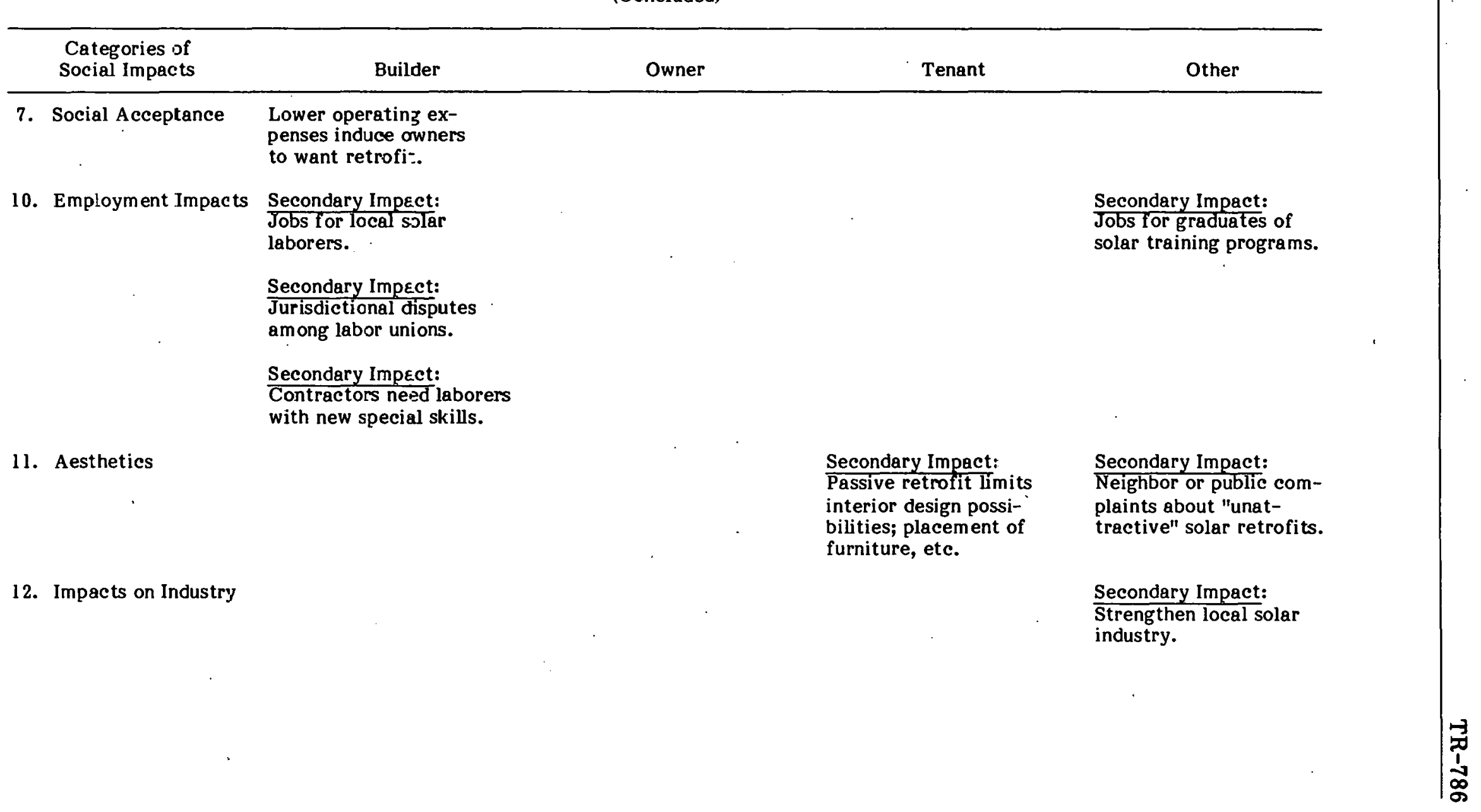




\subsubsection{Consumer Protection Program}

To provide consumers with more reliable information about solar products, this initiative would both extend the existing voluntary product testing program to a wider range of solar products and expand the development of quality and performance standards. While standardized product information may enhance consumer evaluation of the reliability and effectiveness of solar products, the costs of product testing may prove to be a disadvantage to small, less well capitalized solar firms in the industry. Likely social impacts are presented in Table 6-5. 
Table 6-5. SOCIAL IMPACTS ON RESIDENTIAL RENTAL GROUPS OF A CONSUMER PROTECTION PROGRAM

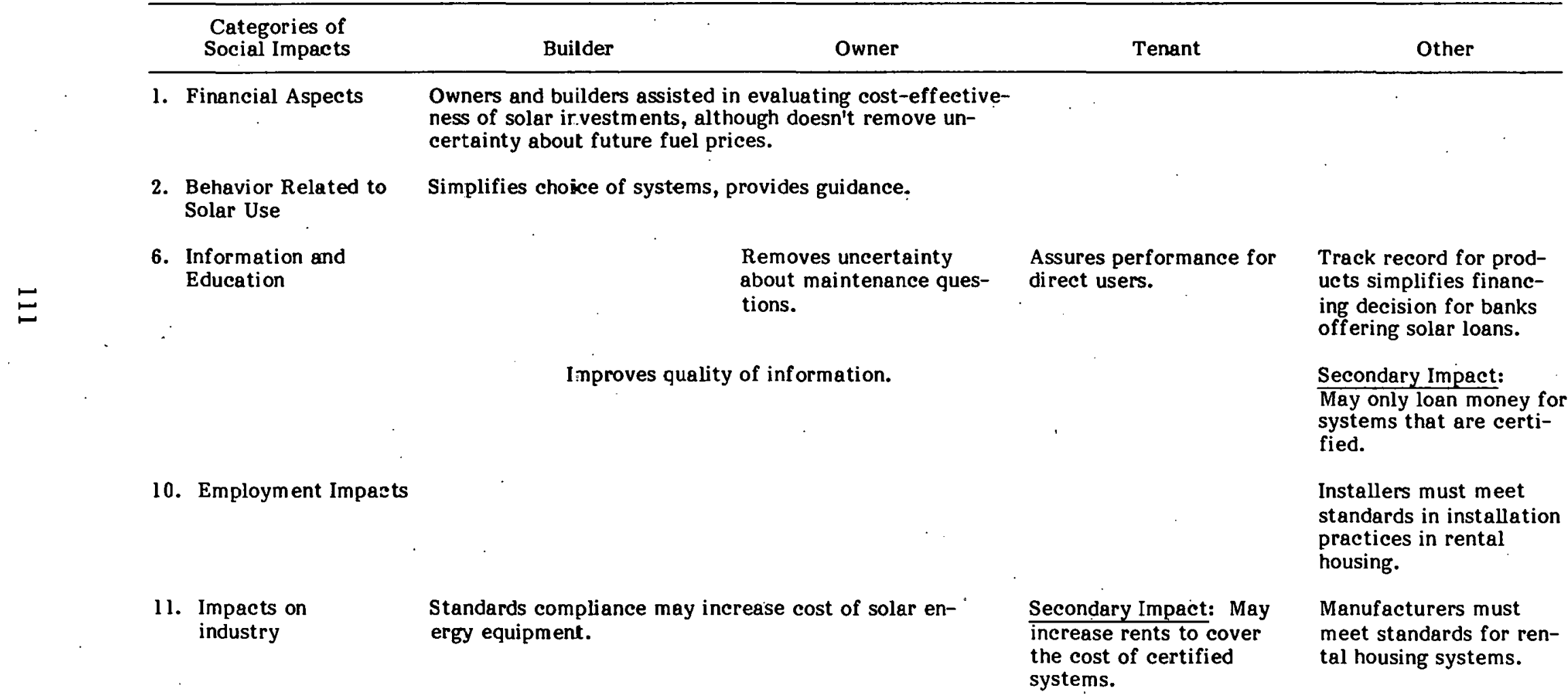




\subsubsection{Tax Credit for Leased Solar Equipment}

This policy would extend the federal tax credit to those who lease solar energy equipment from leasing companies. This policy could have an important effect by reducing rental housing owners' uncertainty about system costs and maintenance while providing a financial incentive to use solar energy. Leasing and the accompanying credit apply best to owners of master-metered buildings where utility charges are covered in the tenants' rent. The likely social impacts are presented in Table 6-6. 
Table 6-6. SOCIAL IMPACTS ON RESIDENTIAL RENTAL GROUPS OF A TAX CREDIT FOR LEASED SOLAR EQUIPMENT

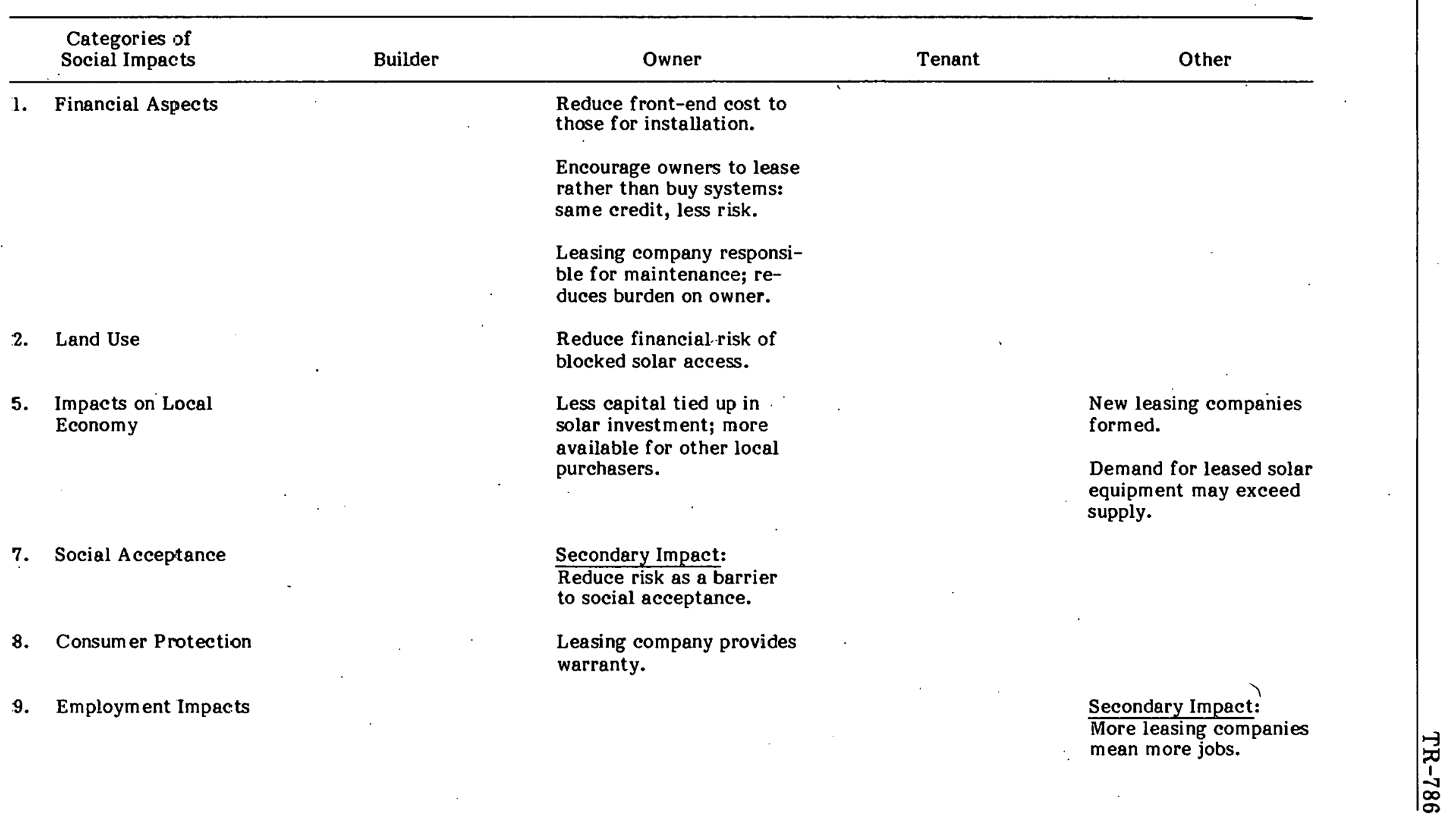


Table 6-6. SOCLAL IMPACTS ON RESIDENTIAL RENTAL GROUPS OF A TAX CREDIT FOR LEASED SOLAR EQUIPMENT (C:oncluded)

Tenant

Other

Secondary Impact:

Jur isdictional disputes

among unions and labor-

ers over installation of

solar equipment.

Secondary Impact:

Union pressure on leas-

ing companies to hire

union labor.

13. Quality of Life

Secondery Impact: Owners

of master-metered build-

ings with leased solar

equipment may be less in-

clined to switch to

separate-metering. 


\subsection{SUMMARY AND CONCLUSIONS}

Five proposed policies to encourage the use of solar energy in the residential sector will do little or nothing to stimulate use of solar energy in $35 \%$ of U.S. housing - the rental sector. Rental housing owners make decisions about their properties in ways that differ markedly from those of homeowners. In short, rental housing decisions typify business decisions and not family decisions. In rental housing, tenants pay the utility bills either directly (in separately metered buildings) or indirectly (in master-metered buildings). In addition, tenants are constrained both legally and financially from investing in solar energy equipment for their dwelling units. Because the tenants benefit from solar energy use and yet are powerless to make decisions to install solar energy systems, ensuring renters rights to solar energy is extremely complicated.

\subsubsection{Effectiveness of Proposed Policy Initiatives}

While an income tax credit for energy-efficient construction may make an investment in solar energy more attractive, this credit does nothing to reduce the uncertainty owners and builders associate with solar technologies. The general uncertainty contributes to a higher required rate of return on the solar investment, and the credit, at its current level, cannot improve the rate sufficiently. In addition, if a tax credit is restricted to only new construction, it will affect an extremely small proportion of rental housing. It is unlikely that this credit will stimulate construction in a market besieged with problems of declining profitability.

A tax credit for leased property may have more of an impact on rental housing, primarily because leasing reduces uncertainties about the technology. Also, it is easier to terminate a leasing agreement than it is to remove and sell a used solar system. This kind of incentive would be most applicable to owners of master-metered buildings.

As noted, rental housing owners prefer tax incentives to loan guarantees, subsidies, or grants. The Solar Bank will probably do little business with builders and owners of rental property because the choice between a solar bank loan subsidy and a tax credit is fairly even financially, and owners have been shown to prefer tax credits (Booz, Allen \& Hamilton, 1979). Solar bank loans are available to tenants. However, as noted, tenants are severely constrained from investing in solar energy equipment for their rental units.

Financial assistance in the form of grants for public housing solar prototypes, public housing retrofits, and Section 8 retrofits can go far toward heating low-income households with solar energy. These types of programs will be required to ensure an equitable transition to further residential use of solar energy. However, in the case of public housing it may be less expensive to government to require that public housing meet energyefficiency standards, and then provide funding to meet those standards. In the case of privately owned Section 8 subsidized housing, financial incentives for building owners in general will have a longer term and broader impact on rental housing.

The consumer protection policy may reduce owners' uncertainty about system performance, thereby encouraging investment. However, the program is likely to have a detrimental effect on the solar industry, and this may outweigh the perceived need for the Federal Government to ensure system performance. 
In sum, policies effective in encouraging the use of solar energy in rental housing are those that will address the specific concerns of rental housing owners. The proposed policy initiatives studied here are not responsive to owners' concerns or a disaggregated residential sector and, therefore, offer little or no incentive to use solar energy in rental housing.

\subsubsection{Pocus of SIAs}

Exploring likely social impacts of the policy initiatives in the context of the rental housing market afforded an opportunity to demonstrate the importance of specifying groups of people in conducting social assessments. By addressing the question "Who will be affected?" more precise and salient impacts can be delineated. In the rental housing market those affected are the social groups of builders, financiers, property owners, and renters. Impacts on each of these groups are more informative and meaningful than impacts specified for nondescript social groups.

This case application also permitted testing of the social impact categories induced through a synthesis of literature with social effects of energy technologies. The categories appeared to be useful and relatively comprehensive. However, collecting more information from builders, financiers, owners, and renters as well as professional/trade associations would greatly improve the test of the categories. Validating the impacts themselves would help refine the impact categories. 


\section{SECTION 7.0}

\section{CONCLUSION}

This investigation provides the TASE project with several important products. It identifies general social impacts likely to occur if proposed public policy initiatives were enacted. However, the general scope of the study and the state of knowledge of social impacts did not allow investigators to conduct an impact assessment. In addition, the qualitative nature of identifiable impacts made it virt ually impossible to assess the magnitude of impacts, or how many people or groups would be affected, or how intensively impacts would be felt by selected groups or individuals within groups. Also, while we acknowledge that some of the initiatives may have interactive effects that might have had impacts that also were interactive, the limits of the study did not permit that level of analysis.

A second product is a general strategy for investigating social effects of policies, programs, or technologies. The strategy used in this investigation includes a more concise definition of social impact and inductive techniques for organizing social impacts information into categories, identifying the different levels of social impact, and describing an impact on one or more of the levels. The framework would benefit from additional use both to improve upon its utility and reliability as an assessment tool and to flesh out its procedural components.

A third product is a set of recommended actions for DOE to accelerate use of solar energy. These recommendations are presented in Sec. 1.3 by policy initiative. Each recommendation is accompanied by a brief statement of the likely social effect of the action.

A final product of this study is the identification of the importance of focusing social impact studies on components of society. The case application, in which the social groups constitute the residential housing rental market, demonstrates that when groups like property owners and financiers are identified as being affected; more precise and salient impacts can be specified. The identification of how groups like these are affected are specific, real, and informative about impacts. The benefit of focusing an investigation on components of society or perhaps on energy end-use sectors is information that is more real, accurate, and specific about the likely effects of energy policies, programs, or technologies on individuals, groups, or on society as a whole. 


\section{SEPI}




\section{SECTION 8.0}

\section{REFERENCES}

Abt, Clark C.; editor. The Evaluation of Social Programs. Beverly Hills: Sage Publications, Inc.; 1976.

American Society of Planning Officials. Institutional Factors Influencing the Acceptance of Community Energy Systems and Energy-Efficient Community Design: Public Planning, Administration, and Regulation. 1976.

Annual Review of Solar Energy for 1977. Chapter 6: "Major Forces Affecting the Future of Solar Energy." Golden, CO: Solar Energy Research Institute; SERI/TR-54-066; 1978.

Ashworth, John; et al. The Implementation of State Solar Incentives: A Preliminary Assessment. Golden, CO: Solar Energy Research Institute; SERI/TR-51-159; 1979.

Belassa, Bela; Nelson, Richard; editors. Economic Progress: Private Values and Public Policy. Amsterdam: North Holland Publishing Co.; 1977.

Bell, Daniel. The Coming of Post-Industrial Society: A Venture in Social Forecasting. New York: Basic Books, Inc.; 1973.

Bennington, G.; et al. "Solar Energy, A Comparative Analysis to the Year 2020." MeLean, Virginia: MITRE Corporation; 1978.

Berkman, Richard L.; Viscusi, W. Kip. Damming the West. New York: Grossman Publishers; 1973.

Booz, Allen \& Hamilton. Achieving Energy Conservation in Existing Buildings. Prepared for U.S. DOE; Bethesda, MD; May, 1979.

Boulding, Kenneth. "The Social System and the Energy Crisis.". Science 184 (April, 1974); 255-257.

Broom, Leonard; Selznick, Philip. Sociology: A Text With Adapted Readings. New York: Harper \& Row; 1978.

Budnitz, R. J.; Holden, J. P. "Social and Environmental Costs of Energy Systems." In Annual Review of Energy, Vol. 1. Palo Alto, CA: Annual Reviews, Inc.; 1976.

Bureau of the Census: Housing Division. Annual Housing Survey-1977 National Sample-DOE Supplemental Tabulations. Washington, DC; October, 1979.

Burns, Barbara; Mason, Bert; Mikasa, Gail. Assessment of the Labor Market Experiences of CETA-Trained Solar Workers. Golden, CO: Solar Energy Research Institute; SERI/RR-53-396; 1980.

Cambel, Ali B.; et al. Social Assessment of On-Site Solar Energy Technologies. Washington, DC: Office of Energy Programs, George Washington University; 1978. 
Campbell, Angus; Converse, Philip E.; Rogers, Willard L. The Quality of American Life. New York: Russell Sage Foundation; 1976.

Caporaso, James A.; Roos, Leslie L., Jr.; editors. Quasi-Experimental Approaches: Testing Theory and Evaluating Policy. Evanston: Northwestern University Press; 1973.

Christakis, Alexander N. "Forums for Focussed Discussion of Alternatives." Unpublished paper; University of Virginia; 1979.

Christakis, A. N.; Ahmad, R. S. "A Policy Sensitive Model of Technology Assessment." Battelle Columbus Laboratories; 1978.

Christakis, A. N.; Hansen, R.; Mortland, J. "Coal-based Energy Futures: A Workshop Experience." Battelle Columbus Laboratories; May 1978.

Cohen, Steven. The Internal Revenue Code as a Vehicle to Foster Solar Commercialization: The Energy Tax Act of 1978 and Its Progeny. Golden, CO: Solar Energy Research Institute; SERITF-434-374; 1980.

Committee on Nuclear and Alternative Energy Systems, National Research Council. "U.S. Energy Demand: Some Low Energy Futures." Science 800 (1978); 142.

Commoner, Barry; Bohsenbaum, Howard; Carr, Michael; editors. Energy and Human Welfare: Human Welfare: The End Use for Power, Vol. III. New York: MacMillan Inf ormation; 1975.

Congdon, R. J., editor. Introduction to Appropriate Technology: Toward a Simpler LifeStyle. Emmaus, PA: Rodale Press; 1977.

Cook, Jeffrey. "Solar Decision Making." Humanistic Energy Choices, Aspen Energy Forum 1978 Proceedings. Golden, CO: Solar Energy Research Institute.

Cose, Ellis, editor. Energy and Equity: Some Social Concerns. Washington, DC: Joint Center for Political Studies; 1979.

Cramer, James C.; Dietz, Thomas; Johnston, Robert A. "Social Impact Assessment. of Regional Plans: A Review of Methods and Issues and a Recommended Process," in Policy Sciences 357; Amsterdam; 1978.

De Neufville, Judith Innes. Social Indicators and Public Policy. New York: Elsevier Scientific: Puhlishing rn.; 1975,

Duff ey-Armstrong, Marilyn; Armstrong, Joe E. Community Impediments to Implementation of Solar Energy. Lawrence Berkeley Laboratories; June, 1979.

Duhl, L. J. "Planning and Predicting: Or What To Do When You Don't Know the Variables." Daedalus 96:779-788.

Dunning, Mark C. "A Systematic Approach to Social Impact Assessment." In Wolf (ed.), Social Impact Assessment. Milwaukee, WI: Environmental Design Research Association; 1974. 
Edesess, Michael. Prospects for Investment in Solar Energy. Golden, CO: Solar Energy Research Institute; SERI/TP-351-508; 1979.

Farhar, Barbara C.; Unseld, Charles T.; Caputo, Richard; Easterling, James. Citizen Participation in the Domestic Policy Review of Solar Energy. Golden, CO: Solar Energy Research Institute; SERI/TR-53-126D; 1979.

Farhä, Barbara C.; Weis, Patricia; Unseld, Charles T.; Burns, Barbara A. Public Opinion about Energy: A Literature Review. Golden, CO: Solar Energy Research Institute; SERI/TR-53-155; 1979.

Ferris, Gregg; Mason, Bert. A Review of Regional Economic Models With Special Reference to Labor Impact Assessment. Golden, CO: Solar Energy Research Institute; SERITR-53-100; 1979.

Ferrey, Steven. "How Carter's Solar Program Could Eclipse the Cities." Planning; December, 1978; 20-23.

Finsterbusch, Kurt; Wolf, C. P. Methodology of Social Impact Assessment. Stroudsburg, PA: Dowden, Hutchinson, and Ross, Inc; 1977.

Ford Foundation. Exploring Energy Choices. 1974.

Fox, Karl A. Social Indicators and Social Theory: Elements of an Operational System. New York: John Wiley \& Sons; 1974.

Franta, Gregory. "Problems in Solar Designing and the Architectural Role of SERI." Humanistic Energy Choices, Aspen Energy Forum 1978 Proceedings. Golden, CO: Solar Energy Research Institute; 1979.

Freeman, David M. Technology and Society: Issues in Assessment, Conflict, and Choice. Chicago: Rand MeNally; 1974.

French, David. Appropriate Technology in Social Context. Mt. Rainer, MD: VITA; 1977.

French, David. "Economic and Social Analysis of Renewable Energy Projects: The State of the Art." November 22, 1977.

General Accounting Office. Rental Housing: A National Problem That Needs Immediate Attention. Prepared for the U.S. Congress; CED-80-11; Washington, DC; November, 1979.

Gouldner, Alvin W. The Coming Crisis of Western Sociology. New York: Basic Books; 1970 .

Green, Michael. Licensing Arrangements and the Development of the Solar Energy Industry. Golden, CO: Solar Energy Research Institute; SERI/TR-62-260; 97.9 .

- Harvard Business School. Note on Forms of Real Estate Ownership. Cambridge, MA: Harvard College; 1972.

Hayes, Denis. "Energy for Development: Third World Options." Worldwatch Paper 15; December, 1977. 
Hayes, Denis. "Energy: The Solar Prospect." Worldwatch Paper 11; March, 1977.

Hayes, Denis. "The Solar Energy Timetable." Worldwatch Paper 17; April, 1978.

Healy, Timothy J. Energy and Society. San Francisco: Boyd \& Fraser Publishing Company; 1976.

Helmer, Olaf. "Problems in Futures Research. Delphi and Causal Cross-Impact Analysis." Futures 9:17-31; February, 1977.

Henderson, Hazel. Creating Alternative Futures. Berkeley, CA: Windhover; 1978.

Holloway, Dennis R. "Hard Questions for Soft Societies." Humanistic Energy Choices, Aspen Energy Forum 1978 Proceedings. Golden, CO: Solar Energy Research Institute; 1979.

Howard, Judy. The National Energy Act Statutes and Solar Energy. Golden, CO: Solar Energy Research Institute; SERI/TR-434-424; 1980.

Huevelmans, Martin. The River Killers. Harrisburg, PA: Stackpole Books; 1974.

Hyatt, Richard J. Legal and Institutional Implications of Providing Financial Incentives to Encourage the Development of Solar Technologies. Golden, CO: Solar Energy Research Institute; SERI/TR-62-269; 1979.

Illich, Ivan. Energy and Society. New York: Harper \& Row; 1974.

Jayadev, T. S.; Perkins, F.; Percival, D. An Overview Assessment of Potential Small Electrical Utility Applications of Wind Energy Systems. Golden, CO: Solar Energy Research Institute; SERI/TR-35-086; 1978.

Katz, Milton. "Decision-Making in the Production of Power." Scientific American; September, 1971.

Kelly, John R. "Planned and Unplanned New Town Impacts: Applying a Method." Environment and Behavior; Vol. 7, No. 3; September, 1975.

T،andsberg, Hans H. "Low-Cost, Abundant Energy: Paradise Lost?" Science 184; 1974.

Läwrence, K. A. "All Ovei view of Photovoltaic Environmontal Issues." Presentẹ at II.S. Department of Energy Environmental Control Symposium; Washington, DC, Nov. 28-30, 1978. In Proceedings, Vol 3: Solar Energy, Geothermal Finergy, and Waste Ileat Transmission; September, 1979.

Lawrence, K. A. A Review of the Environmental Effects and Benefits of Selected Solar Energy Technologies. Golden, CO: Solar Energy Research Institute; SERI/TP-53-114R; 1979.

Lawrence, Kathryn A. Selected Solar Energy Technologies. Golden, CO: Solar Energy Research Institute; SERITP-53-114R; 1978.

Lawrence, Kathryn A.; Strojan, Carl; O'Donnell, Daniel. Environmental Assessment of Small Wind Systems: Progress Report. Golden, CO: Solar Energy Research Institute; SERI/PR-354-420; 1980. 
Leviton and Sheppard. Adjusting to Technological Change. New York: Harper \& Row; 1963.

Livingston, Rob. Organized Labor and Solar Energy. Golden, CO: Solar Energy Research Institute; SERI/TR-62-148; 1979.

Lovins, Amory B. Soft Energy Paths. New York: Harper \& Row; 1976.

Lovins, Amory B. "Soft Energy Technologies." In Hollander, Simmons, and Wood (eds.), Annual Review of Energy: Volume III. Palo Alto, CA: Annual Reviews, Inc.; 1978.

Martino, Joseph P.; Lenz, Ralph C., Jr.; Chen, Kuei-Kin. "Technology Assessment: An Appraisal of the State of the Art." Dayton, OH: University of Dayton Research Institute; September, 1978.

Mason, Bert. Labor Manpower and Training Requirements. Technical Progress Report. Golden, CO: Solar Energy Research Institute; 1978.

McEvoy; James III; Dietz, Thomas; editors. Handbook for Environmental Planning, The Social Consequences of Environmental Change. New York: John Wiley \& Sons; 1977.

Messing, Marc; Friesema, H. Paul; Morrell, David. Centralized Power: The Politics of Scale in Electricity Generation. Cambridge, MA: Oelgeshlager, Gunn, \& Hain, Publishers, Inc.; 1979.

Miles, Rufus E., Jr. Awakening from the American Dream, The Social and Political Limits to Growth. New York: Universe Books; 1976.

Milne, Murray; Adelson, Marvin; Corwin, Ruthann. "Three Solar Urban Futures: Characterization of a Future Community Under Three Energy Supply Scenarios." Los Angeles: Urban Innovations Group; April, 1979.

Murdoch, Steve H. "The Potential Role of the Ecological Framework in Impact Analysis." Rural Sociology 44(3); 1979; 543-565.

National Center for Appropriate Technology (NCAT). Energy and the Poor: An Imperative for Action. Washington, DC; December, 1979.

Noun, Robert J. Product Liability and Small Wind Energy Conversion Systems (SWECS): An Analysis of Selected Issues and Policy Alternatives. Golden, CO: Solar Energy Research Institute; SERI/TR-354-365; 1979.

Odland, Robert. The Implementation of State Solar Incentives: State Testing and Certification. Golden, CO: Solar Energy Research Institute; SERI/TR-51-162; 1979.

Ohi, James M. A Method to Assess and Aggregate the Effects of Solar Technology Deployment on Social and Ecological Systems. Golden, CO: Solar Energy Research Institute; SERI/TR-53-081; 1978.

Olsen, Marvin E.; Merwin, Donna J. "Toward a Methodology for Conducting Social Impact Assessments Using Quality of Social Life Indicators." In Finsterbush and Wolf (eds.), Methodology of Social Impact Assessment. Stroudsburg, PA: Dowden, Hut chinson, and Ross, Inc.; 1977; 43-63. 
Ostendorf, David L. "Community Development in the Age of Energy Transition." Paper presented at Annual Meeting of the Illinois Community Development Society, Carbondale, IL; April, 1980.

O'Toole, James. Energy and Social Change. Massachusetts Institute of Technology; 1976.

Peelle, Elizabeth. Social Considerations Relative to Impacts of Decentralized Solar Technologies. Oak Ridge, TN: Oak Ridge National Laboratory; 1980.

Peelle, Elizabeth; Schwietzer, Martin; Shorre, Philip; Pussman, Bradford. A Study of the Cherokee Nuclear Station: Projected Impacts, Monitoring Plan and Mitigation Options for Cherokee County, South Carolina. Oak Ridge, TN: Oak Ridge National Laboratory; 1980.

Peelle, Elizabeth. Mitigating Community Impacts of Energy Development: Some Examples for Caal and Nuclear Generating Plants in the United States. Oak Ridge, TN: Oak Ridge National Laboratory; 1978.

Pollock, Peter. The Implementation of State Solar Incentives: Land-Use Planning to Ensure Solar Access. Golden, CO: Solar Energy Research Institute; SERI/TR-51-163; 1979.

Posner, David; Costello, Dennis. Photovoltaics Procurement Strategies: An Assessment of Supply Issues. Golden, CO: Solar Energy Research Institute; SERI/TR-352-298; 1980 .

Ramsay, William; Cecelski, Elizabeth. "Energy, Scale, and Society." Draft article. Resources for the Future, 1755 Massachusetts Avenue, N. $\bar{W}$. , Washington, DC 20036; April, 1980.

Keader, Mark. "Energy Choices and Human Values." Humanistic Energy Choices, Aspen Energy Forum 1978 Proceedings. Golden, CO: Solar Energy Research Institute; 1979.

Real Estate Research Corporation. Selling the Solar Homes 180, Market Findings for the Housing Industry. HUD Solar Demonstration Program. Chicago, IL: RERC; 1980 .

Roessner, David J.; Piernot, Craig; Green, Bruce; Ashworth, John; deKieffer, Rob; Neuendorff er, Jean. Making Solar Laws Work: A Study of State Solar Incentives. Volume II. Golden, CO: Solar Energy Research Institute; SERITR-352-583; 1980.

Rogers, Paul, editor. Future Resources and World Develogment. New Yök: Pleinum Press; 1976.

Rosenbaum, Walter A. The Politics of Environmental Concern. New York: Praeger Publishers; 1976.

Runyan, Dean. "Tools for Community-Managed Implementation Assessment." Journal of the American Institute of Planners 43, No. 2: 125-135; 1977.

Schaller, David. Energy Policy in a Changing Social Order. Golden, CO: Solar Energy Research Institute; SERITP-355-510; 1979. 
Schumacher, E. F. Small is Beautiful: Economics As If People Mattered. New York: Harper \& Row; 1973.

Schwab, Charlotte. Environmental and Institutional Considerations in the Development and Implementation of Biomass Energy Technologies. Golden, CO: Solar Energy Research Institute; SERI/TR-62-264; 1979.

Select Committee on Small Business and the Committee on Interior and Insular Affairs, U.S. Senate. "Alternative Long-Range Energy Strategies." Washington, DC: U.S. Government Printing Office; 1976.

Shields, Mark A. "Grounded Theory Construction in Social Impact Assessment." In Finsterbush and Wolf (eds.), Methodology of Social Impact Assessment; 1977; 64-73.

Shields, Mark A. "Social Impact Studies: An Expository Analysis." Environment and Behavior; Vol. 7, No. 3; September, 1975.

Smith, Grahame J. C.; Steck, Henry J.; Surette, Gerald. Our Ecological Crisis. New York: MacMillan Publishing Co., Inc.; 1974.

Smith, R. Jeffery. "Wind Power Excites Utility Interests." Science 207 (February 15, 1980); 739-742.

Social Assessment of On-Site Solar Energy Technologies. George Washington University. Washington, DC: U.S. Department of Energy, Office of Energy Research Satellite Power System Project Office; 1979.

Solar Energy in Review, Chapter 8. Unpublished draft. Golden, CO: Solar Energy Research Institute; 1979.

Spivak, Paul. Land-Use Barriers and Incentives to the Use of Solar Energy. Golden, CO: Solar Energy Research Institute; SERITR-62-267; 1979.

Stanford Research Institute. Solar Energy in America's Future: A Preliminary Assessment. Washington, DC: U.S. Energy Research and Development Administration; $\overline{1977 .}$

Suffling, Roger; Michalenko, Gregory. "The Reed Affair: A Canadian Logging and Pollution Controversy." Biological Conservation 17; 1980.

Sullivan, James; Cornman, Ron; Morris, David. Baltimore: Solar and Conservation Potential by the Year 2000. Washington, DC: Institute for Local Self-Reliance; 1979.

Thayer, Robert L. "Bringing Solar Design Out of the Dark Ages." Planning; December, 1978.

Toole, K. Ross. The Rape of the Great Plains. Boston: Atlantic Monthly Press Books; Little, Brown and Company; 1976.

Tuve, George L. Energy, Environment, Populations and Food: Our Four Inter-Dependent Crises. New York: John Wiley \& Sons; 1976. 
Twiss, Robert H.; Smith, Patricia L.; McCleary, Scott T.; Gatzke, Allan E. CommunityLevel Environmental Impacts of Decentralized Solar Technologies. Lawrence Berkeley Laboratories; May, 1979.

U.S. Department of Energy. The Energy Consumer. Washington, DC: U.S. Government Printing Office; 308-564/6742; 1980.

U.S. Department of Energy. Domestic Policy Review of Solar Energy. Washington, DC: U.S. Department of Energy; TID-22834; 1979.

U.S. Department of Energy. Residential Energy Consumption Survey: Conservation. DOE/EIA-0207/3; February, 1980.

U.S. Department of Housing and Urban Development, Rapid Growth from Energy Projects. Ideas for State and Local Action: A Program Guide. Washington, DC: Office of Energy Resources; Federal Energy Administration; 1976.

Ünseld, Charles I; Crews, Robin. Resldential Solar Energy Users: A Review of Empirical Research and Related Literature. Golden, CO: Solar Energy Research Institute; SERI/TR-354-245; 1979.

Unseld, Charles T.; Morrison, Denton E.; Sills, David L.; Wolf, C. P., editors. Sociopolitical Effects of Energy Use and Policy. Study of Nuclear and Alternative Energy Systems. The National Research Council, Supporting Paper No. 5. Washington, DC: National Academy of Sciences, 1979.

Vlachos, Evan. "Technology Assessment and Social Forecasting." Notes from a joint seminar of the Depts. of Sociology and Civil Engineering (S639/CE639). Colorado State University; Ft. Collins, CO; Spring, 1977.

Vories, Rebecca; Strong, Harold. Solar Market Studies: Review and Comment. Golden, CO: Solar Energy Research Institute; SERI/SP-434-475; 1980.

Watkins, George A. "Development of a Social Impact Assessments Methodology (SIAM)." In Finsterbush and Wolf (eds.), Methodology of Social Impact Assessment. 1977 ; 35-42.

Weis, Patricia R. The Status of Information for Consumers of Small Wind Energy Systems. Golden, CO: Solar Energy Research Institute; SERI/TP-51-158; 1978.

Weis, Patricia R. Public Attitudes and Solar Policy. Golden, CO: Solar Energy Research Institute; SERI/TK-51-188; 1979.

Wolf, C. P. "Social Impact Assessment: The State of the Art." Report. Washington, DC: Environmental Design Research Association; 1974.

Young, Louise B. Power Over People. New York: Oxf ord University Press; 1973. 


\section{GLOSSARY}

Aesthetics

Behavior Related to Solar Energy Use

Community (a social level of impact)

Conflict

Consumer Demand/ Protection

Employment Impacts

Financial Aspects of Solar Energy DecisionMaking

Health and Safety Impacts

Impacts on Industry

Information and Education

Institution

International

Implications pertains to sensory perceptions of solar energy installations.

primarily concerns the patterns of daily activities of occupants of solar conditioned buildings.

is a combination of social groups, organizations, and systems of interaction among those elements that perform major social functions having locality relevance and are necessary in day-to-day living (e.g., socialization, social control, social participation, mutual support, security, productiondistribution-consumption) (Warren, 1978).

is a form of social interaction in which groups, organizations, or communal individuals oppose one another. The nature of the social interaction may be overt or threatening, nonviolent or violent, contributory to competition or cooperation. Conflict is inherent in social interaction and is intended to influence, obligate, or compromise another so as to gain control over some limited and valued resource (Olsen, 1978).

concerns the energy demands of consumers and the need to protect consumers of solar energy technologies.

ref ers to vocational training for solar-related jobs, labor conditions of employment and prospects for employment in the solar energy industry.

describes the financial aspects of consumer decision-making, issues that influence the decision-making of financial institutions, and major considerations of relevance to national-level financial policies.

concern different health and safety aspects of solar energy technologies.

concern the effects of solar energy development on the composition, operation, and management of industry. Components include the energy industry, the solar energy industry, the agriculture industry, and nonenergy industry.

concerns the dissemination of facts about solar energy technologies through formal and informal channels.

may be a type of established organization or it may be a formalized practice or procedure (e.g., rules of the game) (Broom and Selznick, 1978).

concern relationships between the development of solar energy in the United States and the world community. 
Land Use

Political Institutions

Quality of Life (QOL)

Social Acceptance

Social Group (a social level of impact)

Social Organization (a social level of impact)

Society (a sociàl

level ol' impret)

Training relates to regulatory strategies of land-use planning for solar energy and general requirements of land-use policy planning for solar technologies.

refers to an established governmental organization or formalized practices. Social impacts can be on political institutions (to affect those institutions) or they can be impacts of existing political institutions on ideas, practices, procedures, and organizations.

entails defining "community" quality of life in individual terms and "individual" quality of life in community terms. Quplity of life concerns satisfaction in a variety of life domains, including environmentäl quaility, values and preferennas, personal factors, shanges in social relationships, employment, community cohorion, and sense of security.

refers to the set of conditions and factors that make solar energy technologies credible as valuable sources of usable energy. Major components are: value judgments about energy, economic motives, appropriate technology, and removal of barriers to acceptance.

is a collective of individuals unified or bound together by distinctive sets of social relations and interactive processes (Broom and Selznick, 1978).

is a dynamic entity solidified by formalized recurrent patterns of interaction within a system that achieves specific goals and objectives (Olsen, 1978).

Is an identifiable collective of social groups of interacting persons Inhabiting a geographicully definable territory and possessing a culture distinguishable from that of similar groups (McGee, 1975).

is the dissemination of technical information to energy technicians and practitioners to assist them in their vocations. 


\begin{tabular}{|c|c|}
\hline \begin{tabular}{|c|c|c|}
$\begin{array}{c}\text { Document Control } \\
\text { Page }\end{array}$ & $\begin{array}{c}\text { 1. SERI Report No. } \\
\text { TR }-743-786\end{array}$ & 2. NTIS Accession No. \\
\end{tabular} & 3. Recipient's Accession No. \\
\hline \multirow{2}{*}{$\begin{array}{l}\text { 4. Title and Subtitle } \\
\text { Likely Social Impacts of Proposed National-Level } \\
\text { Policy Initiatives }\end{array}$} & $\begin{array}{l}\text { 5. Publication Date } \\
\text { March } 1981 \\
\end{array}$ \\
\hline & 6. \\
\hline $\begin{array}{l}\text { 7. Author(s) } \\
\text { C. Piernot, M. A. Rothweiler, A. Levine, R. Crews }\end{array}$ & 8. Performing Organization Rept. No. \\
\hline $\begin{array}{l}\text { 9. Performing Organization Name and Address } \\
\text { Solar Energy Research Institute } \\
1617 \text { Cole Boul evard } \\
\text { Golden, Colorado } 80401\end{array}$ & $\begin{array}{l}\text { 10. Project/Task/Work Unit No. } \\
5642.10 \\
\text { 11. Contract (C) or Grant (G) No. } \\
\text { (C) } \\
\text { (G) }\end{array}$ \\
\hline \multirow[t]{2}{*}{ 12. Sponsoring Organization Name and Address } & $\begin{array}{l}\text { 13. Type of Report \& Period Covered } \\
\text { Technical Report }\end{array}$ \\
\hline & 14. \\
\hline \multicolumn{2}{|l|}{ 15. Supplementary Notes } \\
\hline \multicolumn{2}{|c|}{$\begin{array}{l}\text { 16. Abstract (Limit: } 200 \text { words) } \\
\text { This report describes the results of an investigation of likely social effects } \\
\text { of enacting nine proposed national-level policy initiatives to accelerate devel- } \\
\text { opment and use of solar energy. This study is part of the Technology Assessment } \\
\text { of Solar Energy systems (TASE) project supported by the U.S. Department of } \\
\text { Energy. The report presents general social impact information about the variety } \\
\text { of ways in which the American people could be affected by enactment of these } \\
\text { initiatives. It identifies the effects of each initiative on individuals, } \\
\text { groups, organizations, communities, and society as a whole. In addition, it } \\
\text { provides a framework for organizing a myriad of impact information into a set of } \\
\text { conceptually exclusive impact categories. It illustrates that social impacts } \\
\text { means effects on people as individuals, groups, organizations, and communities } \\
\text { as well as on the infrastructure of society. Finally, it demonstrates the } \\
\text { importance of specifying an audience of impact with a case example from the } \\
\text { residential rental market. }\end{array}$} \\
\hline \multirow{2}{*}{\multicolumn{2}{|c|}{$\begin{array}{l}\text { 17. Document Analysis } \\
\text { a. Descriptors National Energy Plan:T1 ; Social Impact:Q1 ; Socio-Economic Factors:Q1. } \\
\text { Sociology ; Solar Energy; Solar Energy Research Institute; Technology Assessmen } \\
\text { Energy ; Energy Policy; Energy Sources ; Government Policies ; Institutional } \\
\text { b. Identifiers/Open-Ended Terms Factors; National Organizations ; Renewable Energy } \\
\text { Sources; US DOE; US Organizations } \\
\text { c. UC Categories. } \\
58\end{array}$}} \\
\hline & \\
\hline \multirow{2}{*}{$\begin{array}{l}\text { 18. Ayailability Slatement } \\
\text { U.S. D Department of Commerce } \\
5285 \text { Port Royal Road } \\
\text { Sorinafield, Virainia } 22161\end{array}$} & $\begin{array}{l}\text { 19. No. of Pages } \\
139\end{array}$ \\
\hline & \begin{tabular}{l} 
20. Price \\
\multirow{\Psi}{*}{7.25}
\end{tabular} \\
\hline
\end{tabular}

